Andrews University

Digital Commons @ Andrews University

\title{
Un Programa de Retención de Miembros en la Iglesia Adventista de Pueblo Nuevo, Solistahuacán, Chiapas
}

Moises Espinoza

Andrews University

Follow this and additional works at: https://digitalcommons.andrews.edu/dmin

Part of the Practical Theology Commons

\section{Recommended Citation}

Espinoza, Moises, "Un Programa de Retención de Miembros en la Iglesia Adventista de Pueblo Nuevo, Solistahuacán, Chiapas" (2002). Professional Dissertations DMin. 487.

https://dx.doi.org/10.32597/dmin/487

https://digitalcommons.andrews.edu/dmin/487

This Project Report is brought to you for free and open access by the Graduate Research at Digital Commons @ Andrews University. It has been accepted for inclusion in Professional Dissertations DMin by an authorized administrator of Digital Commons @ Andrews University. For more information, please contact repository@andrews.edu. 


\begin{abstract}
A PROGRAM TO RETAIN MEMBERS IN THE SEVENTH-DAY ADVENTIST CHURCH IN PUEBLO NUEVO, SOLISTAHUACÁN, CHIAPAS
\end{abstract}

by

Moisés Espinoza Almazán

Adviser: Ricardo Norton 


\title{
ABSTRACT OF GRADUATE STUDENT RESE $690^{\circ}-I$ \\ Dissertation
}

\author{
Andrews University \\ Seventh-day Adventist Theological Seminar. \\ Montemorelos Extension
}

Title: A PROGRAM TO RETAIN MEMBERS IN THE SEVENTF

36 CHURCH IN PUEBLO NUEVO, SOLISTAHUACÁN, CHIF

Name of researcher: Moisés Espinoza Almazán

Name and degree of faculty adviser: Ricardo Norton, D.Min.

Date completed: July 2002

The goal of the Gospel Commission is to make disciples, not only to baptize them. Making a disciple out of a new convert requires the participation of the pastor and of mature church members. This results in the design and implementation of a program to retain members.

The Bible emphasizes the retention of church members, using different Greek terms. The most common is menō. The Bible also presents examples of church leaders who affirmed the believers.

Ellen G. White asks members and pastors to retain those who are new in the church. She suggests different methods. She speaks of the responsibility of the pastor, of friendship, of missionary service, of the part that worship services and programs play in 
keeping members, and of the usefulness of small groups.

The study done among members of the Seventh-day Adventist Church of Pueblo Nuevo, Solistahuacán, Chiapas, showed that the apostasy rate is high: from 1990 through $1999,65.97$ percent of the number baptized during the same period left the church. The study also showed the reasons why members leave the church: poor devotional life, lack of friendship with other members, lack of pastoral visitation, conflicts among church members, personal sins, and a lack of adaptation to the Adventist lifestyle.

An analysis of the literature indicates that the reasons for apostasy relate to church life rather than to doctrine. Other authors note the same reasons for apostasy as those given in Pueblo Nuevo.

On the basis of the research done, the following retention strategies are recommended:

1. Instruct a group of lay leaders during four weeks so that they may teach the families of the church to maintain a healthy devotional life. These instructors will each take a group of members and show them how to have family worship and how to study the Bible systematically. After two cycles in one year, the plan should be evaluated.

2. Organize a visitation program by the pastor and local lay leaders. This program will include visiting the families of all the churches in the district. The pastor can multiply himself through the lay leaders.

3. Include in the church year special weeks to foster good relations among members (Friendship Weeks), during which nearby churches are included in the activities. These programs may be directed by the youth, by Sabbath School leaders, or by social activities leaders. 


\section{SÍNTESIS}

\section{UN PROGRAMA DE RETENCIÓN DE MIEMBROS EN LA IGLESIA ADVENTISTA DE PUEBLO NUEVO SOLISTAHUACÁN, CHIAPAS}

\section{por}

Moisés Espinoza Almazán

Asesor: Ricardo Norton 


\title{
SÍNTESIS DE TESIS DOCTORAL
}

\author{
Andrews University \\ Seventh-day Adventist Theological Seminary \\ Extensión Montemorelos
}

\section{Título: UN PROGRAMA DE RETENCIÓN DE MIEMBROS EN LA IGLESIA ADVENTISTA DE PUEBLO NUEVO SOLISTAHUACÁN, CHIAPAS.}

Nombre del investigador: Moisés Espinoza Almazán

Nombre y grado del profesor asesor: Ricardo Norton, D.Min.

Fecha de terminación: Julio de 2002.

La meta de la Gran Comisión es hacer discípulos, no sólo bautizar. Convertir a un recién ingresado a la iglesia en discípulo requiere la participación del pastor y de miembros de iglesia que sean maduros. Esto lleva al diseño e implementación de un programa de retención de miembros.

La Biblia hace énfasis en la retención de los miembros que ingresan a la iglesia, utilizando diferentes términos griegos. El principal de ellos es el verbo menō. Además presenta ejemplos de líderes cuya función consistía en afirmar a los creyentes.

También Elena G. de White pide a los miembros y pastores retener a los recién ingresados a la iglesia. Ella misma sugiere diferentes métodos. Habla de la responsabilidad del pastor, del compañerismo, del servicio misionero, del papel que 
desempeñan los cultos y programas y la utilidad de los grupos pequeños.

El estudio realizado en la Iglesia Adventista de Pueblo Nuevo Solistahuacán, Chiapas demostró que existe 78,68 por ciento de apostasía debido a que no hay programas de retención. También demostró que existen razones por la cuales los miembros abandonan la iglesia. Estas razones son: vida devocional pobre de los miembros, falta de compañerismo con otros miembros, falta de visitación pastoral, los conflictos existentes entre miembros, pecados personales y la no adaptación al estilo de vida adventista.

El análisis de la literatura indica que éstas son razones generalizadas. Estudios realizados por otros autores muestran que las razones, por las cuales existe apostasía en Pueblo Nuevo, son las mismas por las cuales existe apostasía en otros lugares y otras iglesias.

Por los resultados de esta investigación se sugiere implementar las siguientes estrategias de retención:

1. Instruir durante cuatro semanas a un grupo de líderes laicos sobre cómo ayudar a las familias de la iglesia a mantener una vida devocional saludable. Después de instruirlos, se deben distribuir los miembros o familias entre los líderes para ser enseñadas acerca de cómo tener y mejorar el culto familiar y cómo estudiar la Biblia sistemáticamente. Este plan puede ser implementado dos veces en el año para poder ser evaluado y actualizado.

2. Un programa de visitación pastoral realizado por el pastor y líderes laicos. Este programa de visitación incluye la atención de familias y de iglesias del distrito. El pastor puede multiplicarse mediante los líderes laicos. 
3. Incluir en el programa anual de la iglesia semanas especiales donde se

fomenten las buenas relaciones entre los miembros (semana de la amistad) e intercambio de programas con otras iglesias. Pueden ser programas de jóvenes, de escuela sabática o actividades sociales. 


\title{
Andrews University \\ Seventh-day Adventist Theological Seminary \\ Extensión Montemorelos
}

\section{UN PROGRAMA DE RETENCIÓN DE MIEMBROS EN \\ LA IGLESIA ADVENTISTA DE PUEBLO NUEVO SOLISTAHUACÁN, CHIAPAS}

\author{
Tesis \\ Presentada en cumplimiento parcial \\ de los requisitos para el grado de \\ Doctor en Ministerio
}

$\therefore$ por

Moisés Espinoza Almazán

Julio de 2002 

PROGRAMA DE RETENCIÓN DE MIEMBROS EN LA IGLESIA ADVENTISTA DE PUEBLO NUEVO SOLISTAHUACÁN, CHIAPAS

Tesis

presentada en cumplimiento parcial de los requisitos para el grado de Doctor en Ministerio

por

Moisés Espinoza Almazán

APROBADO POR:

recardo Anton

Asesor,

Coordinador, Extensión Montemorelos, Ricardo Norton
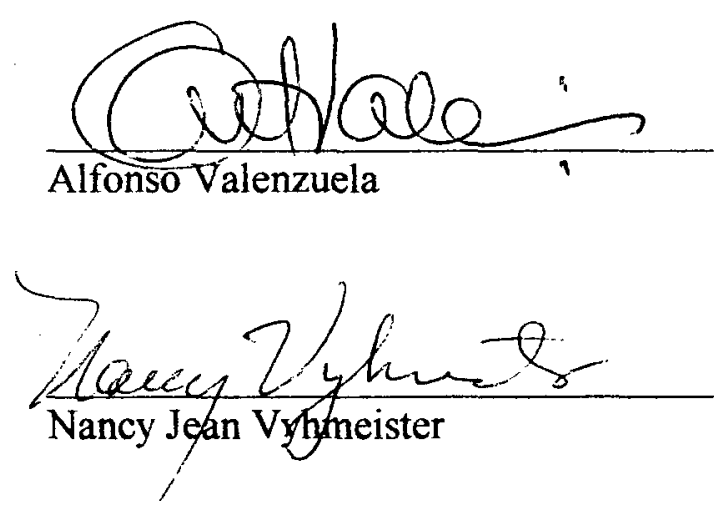
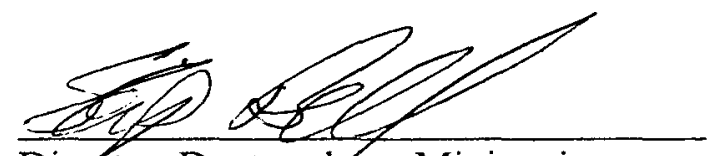

Dixector, Doctorado en Ministerio,

Skip Bell

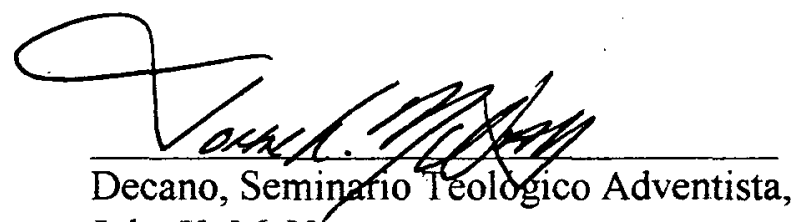

John K. McVay

December 2,2002

Fecha de aprobación 
A mi esposa María del Pilar

y a mis hijas Ruth y Hulda

por el apoyo incondicional que recibí

y con quienes espero estar en el

Reino de los cielos 


\section{INDICE DE CONTENIDO}

LISTA DE TABLAS $\ldots \ldots \ldots \ldots \ldots \ldots \ldots \ldots$ vii

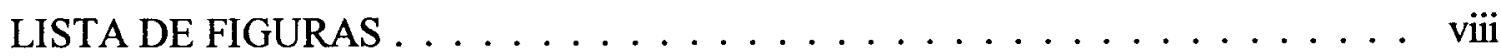

\section{Capítulo}

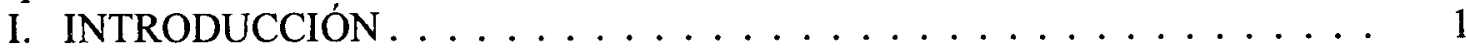

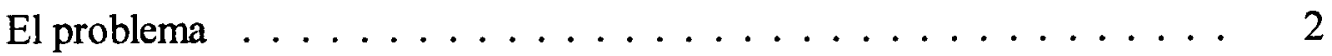

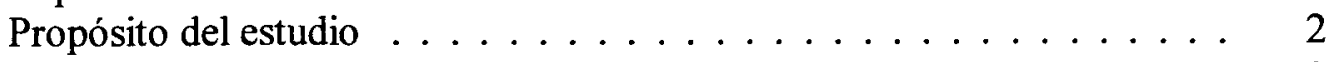

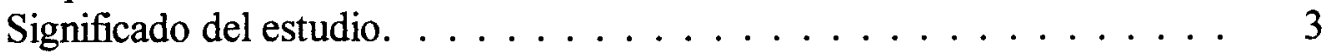

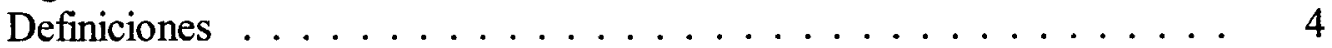

Esbozo de la tesis $\ldots \ldots \ldots \ldots \ldots \ldots \ldots \ldots$

II. FUNDAMENTOS PARA LA RETENCIÓN DE MIEMBROS . . . . . . . . 7

La retención según la Biblia $\ldots \ldots \ldots \ldots \ldots \ldots \ldots$

El verbo menō en Juan $15 \ldots \ldots \ldots$

Confirmación de los creyentes . . . . . . . . . . . . . 12

La retención según Elena G. de White . . . . . . . . . . . . 13

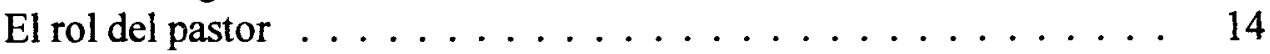

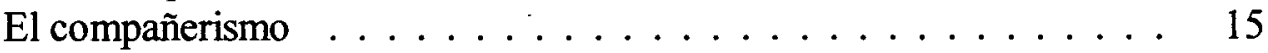

El servicio misionero $\ldots \ldots \ldots \ldots \ldots \ldots \ldots \ldots \ldots$

El estudio de las Escrituras . . . . . . . . . . . . . . . . . . . 17

Los cultos y programas de la iglesia . . . . . . . . . . . . . 19

Los grupos pequeños . . . . . . . . . . . . 20

La retención según otros autores ... . . . . . . . . . . . 21

Razones por las que existe pérdida de miembros . . . . . . . 23

Estrategias que contribuyen a la retención de miembros . . . . . . 25

Programas adecuados . . . . . . . . . . . . . 26

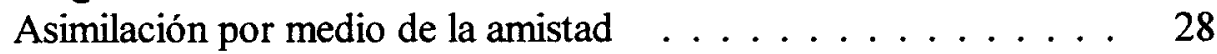

Enseñanza de métodos de trabajo $\ldots \ldots \ldots \ldots \ldots \ldots$

Períodos pastorales largos . . . . . . . . . . . . 32

Predicación bíblica efectiva $\ldots \ldots \ldots \ldots \ldots \ldots$

La autoridad espiritual de los líderes . . . . . . . . . . . . . 34

Grupos pequeños . . . . . . . . . . . . . 35 
III. LA IGLESIA DE PUEBLO NUEVO . . . . . . . . . . . . . . . . . . 39

Contexto geográfico . . . . . . . . . . . . . . . . 39

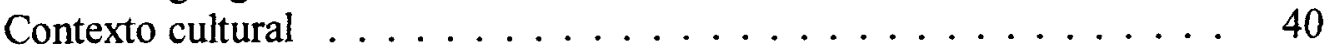

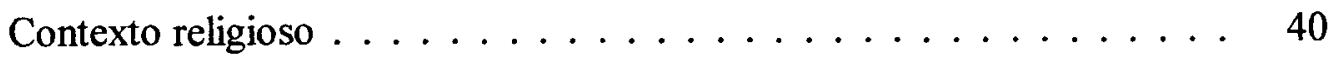

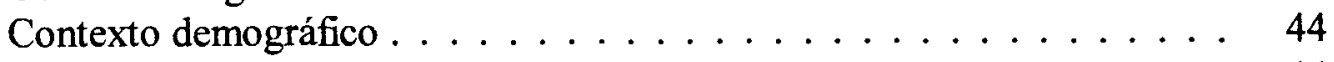

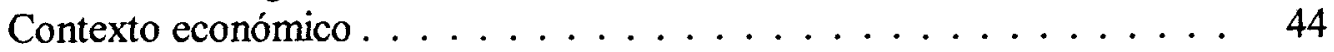

Historia y desarrollo de la iglesia . . . . . . . . . . . . . 45

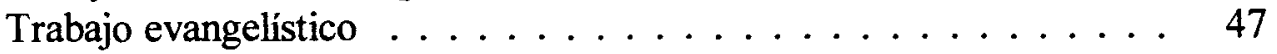

Programas de retención . . . . . . . . . . . . . 47

IV. LA APOSTASÍA EN LA IGLESIA DE PUEBLO NUEVO . . . . . . . . . . 49

Situación general de la iglesia $\ldots \ldots \ldots \ldots \ldots \ldots \ldots$

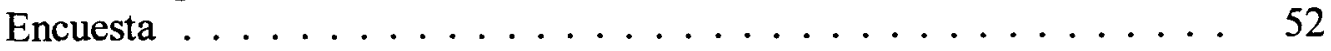

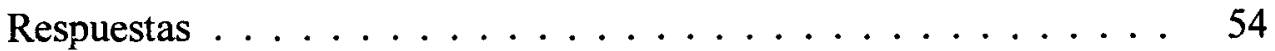

Miembros activos de 9 hasta 30 años de edad . . . . . . . . 54

Miembros activos de más de 30 años de edad . . . . . . . . 59

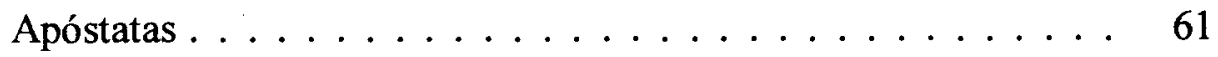

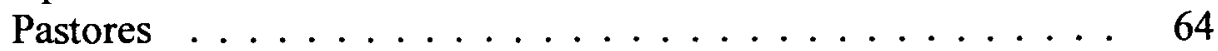

Conclusiones de la aplicación de la encuesta $\ldots \ldots \ldots \ldots \ldots 66$

V. UN PROGRAMA DE RETENCIÓN DE MIEMBROS . . . . . . . . . . 69

Programa para fortalecer la vida devocional $\ldots \ldots \ldots \ldots \ldots . \ldots 72$

Propósito y objetivos del programa $\ldots \ldots \ldots \ldots \ldots \ldots 72$

Instrucción de líderes laicos . . . . . . . . . . . . . . . 72

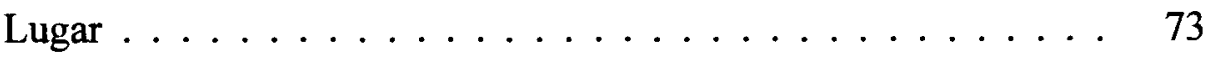

Primera semana . . . . . . . . . . . . 73

Segunda semana . . . . . . . . . . . . . . . . 74

Tercera semana . . . . . . . . . . . . . . . . 75

Cuarta semana . . . . . . . . . . . . . . . 75

Instrucción para familias $\ldots \ldots \ldots \ldots \ldots \ldots \ldots$

Visitación pastoral . . . . . . . . . . . . . . 78

Programa semanal para el pastor . . . . . . . . . . . . . . . 79

Programa diario para el pastor. . . . . . . . . . . . . . 79

Otras actividades que ayudan a la retención $\ldots \ldots \ldots \ldots \ldots$

Resolución de conflictos entre miembros . . . . . . . . . 80

Semana de la amistad . . . . . . . . . . . . . 82

Actividad para un viernes de cada mes . . . . . . . . . . . 83

Intercambio de programas . . . . . . . . . . . . 83

Compañerismo con los miembros . . . . . . . . . . . . . 84

Actividad sugerente para fomentar el compañerismo . . . . . . 85

Participación de los grupos pequeños . . . . . . . . . . . . 86

Adaptación al estilo de vida adventista . . . . . . . . . . . . 89 
VI. RESUMEN, CONCLUSIONES Y REFLEXIONES . . . . . . . . . . . 90

Resumen . . . . . . . . . . . . . . . . . . . 90

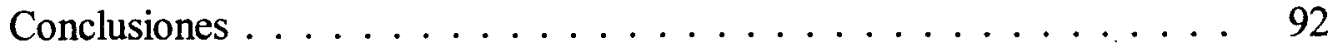

Recomendaciones . . . . . . . . . . . . . . . . 92

Apéndices

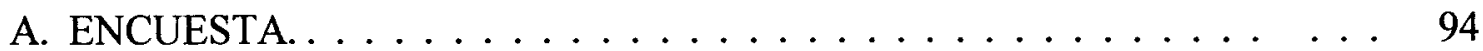

B. BOSQUEJOS PARA LAS CLASES . . . . . . . . . . . . . . . . 92

C. EVALUACIÓN PARA EL PROGRAMA DE ENTRENAMIENTO . . . . . . 105

D. IDEAS PARA EL CULTO FAMILIAR. . . . . . . . . . . . . . 107

E. FORMULARIO PARA EVALUAR EL

TRABAJO DE LOS APÓSTOLES. . . . . . . . . . . . . 110

F. PROGRAMA DE VISITACIÓN PASTORAL. . . . . . . . . . . . 111

G. FORMATO DE AUTOEVALUACIÓN DEL

PROGRAMA DE VISITACIÓN PASTORAL . . . . . . . . . 115

H. ¿ESTOY CRECIENDO EN MI MADUREZ ESPIRITUAL? . . . . . . . . . 117

I. COMO CRECER AL SIGUIENTE NIVEL DE

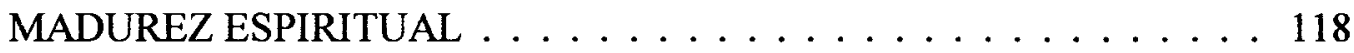

BIBLIOGRAFÍA . . . . . . . . . . . . . . . . . . . . 124

CURRÍCULUM VÍTAE $\ldots \ldots \ldots \ldots \ldots \ldots \ldots \ldots \ldots$ 


\section{LISTA DE TABLAS}

1. Movimiento de pastores en la iglesia de Pueblo Nuevo . . . . . . . . . . 50

2. Comparación de bautismos y apostasía desde 1990 hasta $1999 \ldots \ldots$

3. Resultado y tendencia de las variables que se sugirieron para descubrir razones de apostasía entre miembros activos de 9 a 30 años de edad . . . . 58

4. Principales razones de apostasía según miembros activos de

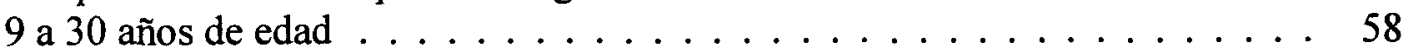

5. Resultado y tendencia de las variables que se sugirieron para descubrir razones de apostasía entre miembros activos mayores de 30 años de edad . . . . . . . . 60

6. Principales razones de apostasía según miembros activos de más de 30 años de edad. . . . . . . . . . . . . . . . . . . . . 61

7. Comparación de personas presionadas para el bautismo según grupos encuestados . . . . . . . . . . . . . . 62

8. Comparación se la actividad en la iglesia de los grupos de apóstatas de 9 a 30 años de edad y mayores de 30 años . . . . . . . . . . 63

9. Resultado y tendencia de las variables que se sugirieron para descubrir razones de apostasía entre apóstatas . . . . . . . . . . . 63

10. Principales razones de apostasía según apóstatas $\ldots \ldots \ldots \ldots$. . . . . . 64

11. Resultado y tendencia de las variables que se sugirieron para descubrir razones de apostasía entre apóstatas . . . . . . . . . . . 65

12. Principales razones de apostasía según apóstatas $\ldots \ldots \ldots 66$

13. Razones de apostasía que tuvieron más puntaje . . . . . . . . . 66

14. Principales razones de apostasía según los cuatro grupos encuestados $\ldots \ldots 67$ 


\section{LISTA DE FIGURAS}

1. Comparación del porcentaje de crecimiento/disminución

entre católicos, evangélicos, sin religión, otras y bíblicos . . . . . . . . 42

2. Crecimiento/decrecimiento de 1989 a 1999 sin incluir muerte y transferencia de miembros . . . . . . . . . . . . 50

3. Porcentaje de miembros separados por muerte, por carta y por apostasía de 1990 a $1999 \ldots \ldots$. . . . . . . . . . . . . . . 51

4. Comparación de los porcentajes de miembros bautizados entre 9 y 15 años de edad, 16 y 20 años y bautizados después de los $21 \ldots \ldots \ldots \ldots 5$

5. Comparación de los miembros activos de hasta 30 años de edad que fueron presionados para ser bautizados y los que se bautizaron voluntariamente . . . 55

6. Comparación entre los miembros de iglesia de 9 a 30 años de edad que tienen y que no tienen cargos, que asisten y que no asisten regularmente y que participan y no participan en actividades en la iglesia . . . . . . . 56

7. Comparación de los presionados para el bautismo con su actividad en la iglesia: Cuántos no tienen cargos, cuántos no asisten a la iglesia y cuántos no participan en actividades . . . . . . . . . . . . . 57

8. Comparación de los miembros activos de más de 30 años de edad que fueron bautizados entre lo 9 y 15 años, 16 y 20 después de los 21 años . . . . . . . 59

9. Comparación de apóstatas que fueron bautizados entre 9 y 15 , 16 y 20 y después de los 21 años de edad . . . . . . . . . . . . 61

10. Comparación de los pastores que fueron bautizados entre los 9 y 15,16 y 20 y después de los 21 años de edad . . . . . . . 6 61 


\section{CAPÍTULO I}

\section{INTRODUCCIÓN}

A menudo la iglesia se reúne en grandes auditorios para la "celebración de la victoria", es decir, el haber alcanzado los blancos que la sección ${ }^{1}$ propuso para el año eclesiástico que terminó. Los informes incluyen el número de personas bautizadas, logrando así lo que se denomina el "blanco de almas".

La Sección Norte de Chiapas ${ }^{2}$ también celebra sus triunfos en ganancia de almas. Desde 1990 hasta 1999 se bautizaron en este campo 44.878 nuevos miembros, un promedio de 4.487,8 miembros por año. Si se toma en cuenta que la Sección Norte tiene 32 distritos, cada uno de ellos logró bautizar, en el mismo período, un promedio de $1.402,5$ personas. $^{3}$

Hasta el 17 de octubre de 2000 este campo tenía 56,091 miembros bautizados en sus registros, lo que significa que cada distrito tenía un promedio de 1.752,8 miembros, siendo todos atendidos por un solo pastor.

\footnotetext{
${ }^{1}$ Para una mejor atención de los miembros, la Iglesia Adventista en México está organizada de la siguiente manera: Un grupo de iglesias y congregaciones forman un distrito que es atendido por un pastor; un grupo de distritos componen una sección y un grupo de secciones establecen una Unión. Cada una de estas entidades comprenden un territorio definido. Los distritos pueden comprender varios municipios; lasección es parte de un estado (o si hay pocos miembros, un estado completo).
}

${ }^{2}$ La Sección Norte de Chiapas es el conjunto de 32 distritos ubicados en la zona Norte del estado de Chiapas, con sede en Pichucalco, Chiapas.

${ }^{3}$ Departamento de Secretaría de la Sección Norte de Chiapas, entrevista por el autor, Pichucalco, Chiapas, 17 de octubre de 2000. 
Si a esta cantidad se suma el crecimiento anual de la década de los 90 , el distrito estaría aumentando su feligresía a razón de 3.155,3 miembros por cada diez años. La Sección tendría 100.969 miembros bautizados al término del mismo período; sufícientes como para formar otra Sección.

Si esto fuera real, cada distrito de la Sección Norte de Chiapas estaría produciendo un distrito nuevo cada diez años, después de los cuales, habría 64; y en los otros diez, tendría 128, suficientes para formar cuatro secciones. Por supuesto que esto no ocurre así. El consenso de los miembros de la iglesia es que no hay un plan de retención para los recién ingresados, por lo cual muchos de los que ingresan, salen por la puerta de atrás al poco tiempo. ${ }^{1}$ Hay una gran necesidad de un programa adecuado de retención que se adapte a las necesidades de cada congregación.

\section{El problema}

La iglesia central de Pueblo Nuevo, Chiapas, tampoco tiene un programa de retención de miembros, a pesar de que es una iglesia misionera. Cada año ingresan nuevos miembros mediante el bautismo. En la última década ésta iglesia bautizó en promedio 29,1 personas por año. Sin embargo, a pesar de este crecimiento no se han plantado nuevas iglesias durante este período, y la misma cantidad de miembros asiste cada sábado a la iglesia. Es evidente que existe una fuga de miembros que hay que parar.

\section{Propósito del estudio}

El problema de la Iglesia Central de Pueblo Nuevo es el mismo que experimenta otras iglesias adventistas. Los pastores de distrito trabajan bajo presión por alcanzar los

\footnotetext{
${ }^{1}$ Alumnos de la Escuela de Teología de la Universidad Linda Vista distribuidos para desempeñar sus prácticas ministeriales en las iglesias de Pueblo Nuevo, preguntaron a los miembros de cada congregación: ¿Existe un plan de retención de miembros? La respuesta siempre fue "No".
} 
blancos de bautismos y descuidan la retención de sus miembros. Parece que hay competencia por bautizar a una mayor cantidad de personas. Se bautizan muchos pero una vez dentro de la iglesia, no se les atienden bien, por consiguiente, pronto se van. La iglesia necesita remediar esta situación mediante un plan de retención.

Este proyecto tiene los siguientes propósitos:

Primero, mostrar evidencias de la deserción y apostasía que existe en la Iglesia Adventista, tomando como muestra la iglesia central de Pueblo Nuevo Solistahuacán, Chiapas.

Segundo, conscientizar a pastores y otros líderes voluntarios de la necesidad de atender a los que están en la iglesia y rescatar a los que han abandonado la fe. A pesar de que es más difícil que un apóstata regrese, es una responsabilidad que la iglesia no debe descuidar.

Tercero, mostrar que la tarea de discipular no termina con el bautismo. El recién nacido no puede caminar solo; hay que enseñarle. Lo mismo pasa con el recién ingresado a la iglesia, hay que enseñarle cómo avanzar en el camino cristiano. Tiene que madurar hasta convertirse en un miembro activo y maduro, capaz de contribuir para que otros, como él, se conviertan en discipulos.

Cuarto, contribuir con un programa que mantenga a los miembros dentro de la iglesia y que sean constantemente nutridos espiritualmente.

\section{Significado del estudio}

Este proyecto ayudará a reducir el índice de apostasía en la Iglesia Adventista de Pueblo Nuevo, Chiapas. Proveerá estrategias que podrán ser implementadas en otras iglesias. Ayudará al fortalecimiento de la iglesia en las áreas débiles, especialmente en la retención de miembros. 


\section{Definiciones}

Discipulo. En esta tesis un discípulo es una persona, miembro de iglesia que participa en las diferentes actividades de la misma; especialmente en la evangelización de otras personas.

Confirmar. Se refiere al trabajo que miembros de iglesia realizan para que una persona recién bautizada esté segura de su decisión de formar parte de la congregación como miembro activo.

Asimilación. Es el estado de un miembro de iglesia, el cual se ha integrado con éxito a cada uno de los grupos y actividades de la iglesia, participando activamente y colaborando para que otros tengan la misma experiencia.

Contextualización del ministerio. Es la adaptación del trabajo pastoral a las diferentes situaciones de la iglesia o de cada miembro en forma individual, ya sea por edad, clase social o sexo. Incluye los programas de trabajo del pastor, ya sea el cuidado de los que ya son miembros como la evangelización de los que no pertenecen a la iglesia.

Periodo pastoral. Tiempo que el pastor permanece en una iglesia o en un distrito, designando por la Sección, para desempeñar las responsabilidades, propias de su profesión.

Marginación. Situación en la cual un individuo o una comunidad se encuentra desatendida por entidades gubernamentales en los asuntos más elementales de su vida, tales como educación, apoyo financiero para el trabajo del campo, servicios de agua, luz, drenaje, y otros.

La voz de la juventud. Manual doctrinal utilizado para realizar campañas de evangelismo dirigidas por los jóvenes de la iglesia. También se refiere al tiempo que dura una campaña, que por lo general, es de una.semana. 
Hermano mayor. Se llama así a un miembro de iglesia asimilado que ayuda a un recién bautizado a crecer espiritualmente hasta llegar a ser asimilado también.

Pérdida de miembros. Expresión utilizada para referirse al abandono de la iglesia por parte de miembros que han caído en apostasía.

Tener cargos en la iglesia. Participar como parte de la directiva de un departamento de la iglesia, como director de Escuela Sabática, diácono, u otro puesto.

Vida devocional. Hábitos que tienen los miembros, el propósito de los cuales es contribuir a su asimilación y fortalecer su ánimo para permanecer dentro de la iglesia. Tales hábitos son estudiar la Bíblia y orar por la mañana y/o por la tarde en forma sistemática.

Estilo de vida adventista. Estilo de vida que consiste en implementar los principios adventistas concernientes a la alimentación, vestido, recreación, etc., a la vida diaria del miembro de iglesia.

Apóstata. En esta tesis se le llama así a una persona que abandona la iglesia por haberse adherido a otra religión, por haber cometido pecados que provoquen la separación de la iglesia y por dejar de asistir a la iglesia definitivamente, renunciando a su fe. Sin embargo, si su ausencia a la iglesia es por enfermedad o alguna discapacidad no puede ser catalogada como apóstata. Para referirse a la apostasía también se utilizan expresiones como deserción y abandono de la iglesia.

\section{Esbozo de la tesis}

La tesis está dividida en cinco capítulos incluyendo la introducción. El capítulo 2 presenta los fundamentos teóricos para la retención de miembros. Establece que el bautismo de una persona no es la meta del evangelismo; el objetivo es convertirla en discípulo. Estudia el tema de la permanencia en la iglesia en el Nuevo testamento y los 
escritos de Elena G. de White.

El capítulo 3 analiza la situación de la iglesia de Pueblo Nuevo en sus diferentes contextos. También hace un estudio de los métodos evangelísticos y de retención que se implementaron desde su inicio hasta hoy.

El capítulo 4 evalúa la situación de la iglesia en relación con la apostasía de miembros. En este trabajo se analizaron las respuestas a una encuesta aplicada a cuatro grupos de personas.

El capítulo 5 aborda los resultados de las encuestas mediante sugerencias para la retención de miembros. Son ideas personales combinadas con lo que dicen la Biblia y otros autores.

En el capítulo 6 se ofrece una conclusión seguida de algunas recomendaciones. Finalmente, se completa el trabajo con ocho apéndices y la bibliografia. 


\section{CAPÍTULO II}

\section{FUNDAMENTOS PARA LA RETENCIÓN DE MIEMBROS}

Este capítulo presenta las bases para la retención de nuevos miembros de iglesia. Empieza con el fundamento bíblico que incluye un análisis de términos griegos, especialmente del verbo menō, que se encuentra repetidas veces en Juan 15 . Posteriormente presenta consejos de Elena G. de White en los que esta autora invita a los líderes de la iglesia a velar por los recién bautizados.

\section{La retención según la Biblia}

Al analizar Mt. 28:19, debe notarse que la gran comisión consiste en "hacer discípulos", expresión que se traduce del imperativo mathēteusate, que proviene del verbo mathēteuō. Este verbo significa enseñar o instruir a alguien con el fin de que siga las instrucciones de su maestro. Un discípulo es un aprendiz. ${ }^{1}$ El verdadero discípulo es el que permanece al lado de su maestro, el que colabora en la edificación y crecimiento del cuerpo de Cristo que es la iglesia. No es sólo un miembro o un cristiano más.

Cristiano se refiere a una posición como miembro de la familia de Dios, mientras que discípulo enfatiza un proceso. Discípulo es un seguidor, una persona que está en el proceso de aprendizaje. No sólo es salvado por Cristo sino que es controlado y

\footnotetext{
${ }^{1}$ Enhanced Strong's Lexicon, Compubiblia, Logos Library System, 1995, ver "mathēteusate".
} 
utilizado por él. ${ }^{1}$

E1 Nuevo Testamento usa mathētēs para referirse a los discípulos de Juan el Bautista y a los de Jesús. ${ }^{2}$ Ser mathetès es más que sentarse a escuchar; es seguir a un maestro y aprender a su lado. La Biblia denomina así a los apóstoles (Mt. 10:1; $11: 1$ ) y a los creyentes en general (Mt. 10:42; Hch. 6:1,2,7). ${ }^{3}$

En armonía con Mt. 28:19, hacer discípulos es la meta del evangelismo.

Bautizar es sólo uno de los medios para alcanzar esta meta; sin embargo hay iglesias que se preocupan más de bautizar que de retener a los que se bautizan. Peter Wagner escribe que uno de los errores más comunes en la evangelización consiste en "confundir los medios con las metas". ${ }^{4}$ El bautismo es un medio para el discipulado, pero el discipulado es la base para la conservación de miembros.

Existen por lo menos doce verbos griegos utilizados para expresar la idea de retener a los creyentes. Estos verbọs son: histēmi, que se puede traducir como “establecer, poner", 5 y en algunos textos significa “animar y afirmar" (2 Ts. 2:15; Ro.

$1: 11$; Stg. 5:8, 9; 2 P. 1:12; 1 Ts. 3:2, 13; Hch. 15:32); rizoō, "hacer que algo se arraigue,

${ }^{1}$ James A. Cress, You Can Keep Them If You Care: Helping New Members Stay on Board (Silver Spring, MD: Ministerial Association Resource Center, General Conference of Seventh-day Adventists, 2000), 16, 17.

2Justo González, “Discipulo”, Diccionario ilustrado de la Biblia, ed. Wilton M. Nelson (Miami: Caribe, 1981), 170, 171.

${ }^{3}$ Ibid.

${ }^{4}$ Peter Wagner, "Las cuatro estrategias de la misión", en Misión mundial: Un análisis del movimiento cristiano mundial, 3 vols., ed. Jonatán P. Lewis (Miami: Unilit, 1990), 2:97.

${ }^{5}$ Guillermo H. Davis, Gramática elemental del griego del Nuevo Testamento (El Paso: Casa Bautista, 1988), 231. 
estar firmemente asentado"1 (Col. 2:7); epoikodomeō, "sobreedificar, construir" (Col. 2:7); bebaioō, "asentar, corroborar, confirmar" (Col. 2:7); stereoō, "fortalecer, vigorizar, consolidar" (Hch. 16:5); katartizō, "poner de nuevo en orden, completar, preparar, perfeccionar" (1 P. 5:10); sthenoō, "robustecer" (1 P. 5:10); tithēmi, "poner, colocar, establecer" (1 P. 5:10); parakaleō, "pedir, exhortar, consolar" (1 Ts. 3:2, 13; Hch. 15:32); apaggellō, "anunciar, proclamar" (Hch. 15:27); diastellomai, "dar órdenes, mandar, dar instrucciones" (Hch. 15:24) y menō, "permanecer, aguardar" (Jn. 6:56; 8:31, 44; 15:4, 5, $6,7,9) .^{2}$

La iglesia primitiva mostró interés por que los convertidos fueran afirmados. Este interés puede verse en Hch. 9:31, "y se acrecentaban fortalecidos por el Espíritu Santo"; en Hch. 16:5, "así que las iglesias eran confirmadas en la fe, y aumentaban en número cada día". ${ }^{3}$ Basándose en Hch. 21:20, Vergil Gerber afirma que por lo menos diez mil judíos permanecían en el evangelio. ${ }^{4}$

Es evidente que la iglesia primitiva no experimentó mayores pérdidas de miembros, aunque hubo quienes abandonaron la iglesia: Jesús perdió a Judas, uno de los doce; Pablo menciona en forma específica a Demas (2 Ti. 4:10), quien lo abandonó "amando este mundo". Cuando le escribe a Tito, le instruye diciéndole que "al hombre que cause divisiones, después de una y otra amonestación deséchalo, sabiendo que el tal

\footnotetext{
${ }^{1}$ Vocabulario griego del Nuevo Testamento (Salamanca, España: Sígueme, 1998), ver "rizoō".

${ }^{2}$ Ibíd., ver cada una de las palabras.

${ }^{3}$ En este trabajo se emplea la Versión Valera Revisada 1960.

${ }^{4}$ Vergil Gerber, God's Way to Keep a Church Going and Growing (South Pasadena: William Carey, 1973), 16, 17.
} 
se ha pervertido" (Tit. 3:10,11). Hubo otros que apostataron por poner su atención en la "falsamente llamada ciencia" (1 Ti. 6:21).

Cuando Pablo escribió a los tesalonicenses hizo referencia a los que andaban desordenadamente, pidiendo que los hermanos se apartaran de ellos (1 Ts. 3:6). Juan advierte contra los falsos cristos, explicando que "salieron de nosotros" (1 Jn. 2:19), es decir, eran creyentes de la iglesia pero cayeron en apostasía volviéndose un peligro para la unidad y la fe. Por su parte Pablo le advierte a Timoteo que "en los postreros tiempos algunos apostatarán de la fe" (1 Ti. 4:1).

$\mathrm{Al}$ analizar la parábola de la vid de Juan 15 se notará que el verbo menō (permanecer) aparece once veces en diferentes inflexiones. Por esto, conviene hacer un análisis para determinar su significado.

\section{El verbo menō en Juan 15}

En Jn. 15 Jesús utiliza la ilustración de la vid y los pámpanos para enseñar "la importancia de permanecer en Él para poder llevar fruto". La palabra menō se usa once veces, para destacar que "el principal punto, es la comunión y el compañerismo". 1

Jesús utiliza el verbo menō en el sentido de "permanecer". ${ }^{2}$ En sus diferentes formas este verbo puede significar: permanecer, insistir, persistir, quedar, esperar, retener, continuar, subsistir, reposar, esperar y posar. ${ }^{3}$

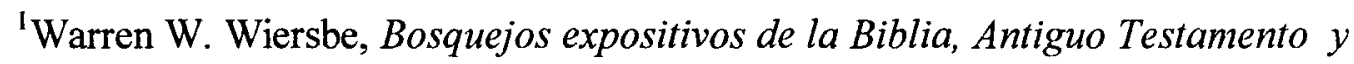
Nuevo Testamento (Nashville: Caribe 1995), ver "permanecer".

${ }^{2}$ W. E. Vine, Diccionario expositivo de palabras del Antiguo y del Nuevo Testamento (Nashville: Caribe, 1999), 654.

${ }^{3}$ Jorge Fitch McKibben, Nuevo léxico griego-español del Nuevo Testamento (El Paso: Casa Bautista, 1978), 183.
} 
La expresión meinate en emoi (Jn. 15:4) subraya el compromiso del creyente que permanece fiel y el compromiso divino de salvar al creyente que permanece fiel. ${ }^{1}$ En esta parábola el verbo menō se usa en el modo imperativo: meinate (vv. 4 y 9), para denotar lo apremiante que es la permanencia en Cristo a fin de robustecer la comunidad y la fe del discípulo, para alentarlo en el esfuerzo moral. ${ }^{2}$ También usa el modo participio, ho menōn (v. 5) para indicar que el miembro es responsable de mantener una acción real en el cuerpo. ${ }^{3}$

El uso de menō también expresa la inmutabilidad de la relación entre Dios y el hombre. Así, Dios permanece en Cristo; los creyentes permanecen en Cristo y Cristo en ellos; Dios permanece en los creyentes y los creyentes en Dios. ${ }^{4}$

La vid y los pámpanos, son el Redentor y sus seguidores, unidos a través de la fe y el amor. Los que rechazan a Jesús quedan excluidos de la comunidad. ${ }^{5}$ El permanecer en Cristo "apunta a la base y fundàmento para un obrar fecundo: la unión con Cristo es lo

'Rudolf Bultmann, "Menō", Diccionario exegético del Nuevo Testamento, 3 vols., ed. Horst Balz y Gerhard Schneider, trad. Constantino Ruiz-Garrido (Salamanca: Sígueme, 1998), 2:223.

${ }^{2}$ Rudolf Schnackenburg, El evangelio según san Juan: Versión y comentario, trad. Claudio Gancho (Barcelona: Herder, 1980), 134.

${ }^{3}$ H. E. Dana y Julius R. Mantey, Manual de gramática del Nuevo Testamento griego (El Paso: Casa Bautista, 1975), 214

${ }^{4}$ Friedrich Hauck, "Menō", Theological Dictionary of the New Testament, 10 vols., ed. Gerhard Kittel, and Gerhard Friedrich, trad. Geoffrey W. Bromiley (Grand Rapids: Eerdmans, 1964-1976), 4:576.

${ }^{5}$ George Beasley-Murray, John, Word Biblical Commentary, 36 (Waco: Word, 1987), Logos Lybrary System. 1995, disco 1. 
que debe perseverar". ${ }^{1}$ Esta unión queda ilustrada con el sarmiento que sólo puede llevar fruto si permanece "en" o unido a la vid. Esta es una relación de fe y verdad, sin las cuales la vida del discípulo tiende a desaparecer. ${ }^{2}$

Jn. 15:1-6 enfatiza la importancia de confiar en Cristo y permanecer unido a él, mientras que el v. 7 enfatiza la permanencia en las palabras de Cristo. ${ }^{3}$

Existen otros textos en las Escrituras que hacen hincapié en la invitación de permanecer en la fe (Hch. 14:22; 11:23; Col. 1:23), en la bondad (Ro. 11:22), en Cristo (Jn. 6:56; 15:4; 1 Jn. 2:6, 28; 3:6), en la palabra de Dios (Jn. 8:31), en la oración (Col. 4:2), en la ley (Stg. 1.25) y en hacer el bien (Ro. 2:7).

La vida de la persona que permanece en Cristo manifiesta obediencia ( $1 \mathrm{Jn}$. 3:24) y la presencia del Espíritu Santo (1 Jn. 4:13). El Espíritu Santo lo motiva para imitar la vida de Cristo ( $1 \mathrm{Jn}$. 2:6) y, como frutos, profesa amor hacia sus hermanos (1 Jn. 2:10), hace la voluntad de Dios (1 Jn. 2:17) y lleva una vida santa (1 Jn. 3:6).

\section{Confirmación de los creyentes}

El Nuevo Testamento registra las historias de líderes de iglesia dedicados a la tarea de confirmar a los creyentes. Entre ellos están: Pablo, que recorría la región de Galacia y Frigia y se comunicaba con las iglesias por medio de cartas (Hch. 18:23; 16:5; Col. $2: 7 ; 2$ Ts. $2: 15$; Ro. 1:11); Santiago; que animaba a la iglesia en vista de que la venida del Señor estaba cerca (Stg. 5:8, 9); Pedro, que reiteraba la importancia de

\footnotetext{
${ }^{1}$ Schnackenburg, 133.
}

${ }^{2}$ Robert Kysar, John, Augsburg Commentary on the New Testament, (Minneapolis: Augsburg, 1986), 237.

${ }^{3}$ Beasley-Murray, disco 1. 
mantenerse firmes en la verdad (2 P. 1:12; 1 P. 5:10); Timoteo, a quien envió Pablo a Tesalónica (1 Ts. 3:2,13) y Bernabé, enviado hasta Antioquía como representante de la iglesia (Hch. 11:22-23). También hubo parejas como Judas y Silas, que fueron enviados a los gentiles convertidos de Antioquia, Siria y Cilicia (Hch. 15:24, 27, 32).

La iglesia primitiva procuraba que los recién bautizados se convirtieran en discípulos bien afirmados. Un ejemplo es que Pablo recorría "por orden la región de Galacia y de Frigia fortaleciendo a todos los discípulos" (Hch. 18:23). La palabra griega que se utiliza aquí para traducir "fortaleciendo" es epistērizōn (epi + stēreō), que se traduce como "fortalecer", "vigorizar" o "consolidar".

Los apóstoles realizaban la tarea de confirmar a los creyentes en la verdad. Lo hacían mediante la exhortación y consolación con abundancia de palabras (Hch. 14:22; 15:33). Con esta actividad las iglesias eran confirmadas en la fe (Hch. 16:5) y en la doctrina (1 P. 1:12) y se les instaba a perseverar en la oración (Col. 4:2). También Pablo y Silas realizaron la tarea de confirmar las iglesias de Siria y Cilicia (Hch. 15:40, 41) y de Galacia y Frigia (Hch. 18:23). Pero sobre todo, Jesús es quien confirma a los creyentes (Ro. 16:25; 1 Co. 1:8; 2 Co. 1:21; Col. 2:7).

\section{La retención según Elena G. de White}

Elena G. de White ${ }^{2}$ enfatiza la retención de miembros, haciendo referencia a

${ }^{1}$ Vocabulario griego del Nuevo Testamento, 57, 69.

${ }^{2}$ Elena G. White (1827-1915), "Cofundadora de la Iglesia Adventista del Séptimo Día, escritora, conferenciante y consejera. Poseyó lo que la Iglesia Adventista acepta como el don de profecía". Seventh-day Adventist Encyclopedia, 2 vols., ed. Don Neufeld (Hagerstown, MD: Review and Herald, 1996), ver "White, Ellen Gould (Harmon)". 
diversas actividades que los pastores y líderes deben promover. Esta sección presenta comentarios de esta escritora relacionados con el tema. Se inicia con el rol del pastor; después siguen el compañerismo, la preparación para el trabajo misionero, el servicio misionero, el estudio de las Escrituras, los cultos de la iglesia y los grupos pequeños.

\section{El rol del pastor}

Elena de White dice que la orden de Jesús a Pedro, "y tú, vuelto a mí, fortalece a tus hermanos" (Lc. 22: 32), expresa "las responsabilidades que atañen al ministro del evangelio que tiene a su cargo la grey de Dios". " Estas responsabilidades incluyen la retención de los miembros mediante el cuidado de "las ovejas y los corderos, buscando a los perdidos y descarriados, y trayéndolos de vuelta al redil. Debe visitar todas las familias, no meramente como un huésped para gozar de su hospitalidad, sino para inquirir acerca de la condición espiritual de cada miembro de la casa". ${ }^{2}$

La atención a la familia por parte del pastor es un medio eficaz para la retención de miembros. El pastor debe tener una condición espiritual saludable, de manera que pueda tratar a las ovejas con amabilidad y cortesia. De esta manera se llega al corazón de la gente y se puede trabajar con éxito por los padres y los hijos. ${ }^{3}$

La atención pastoral se puede lograr mediante la visitación. La experiencia de Elena de White muestra los resultados. Dice que el sábado 12 de abril de 1873, después 1959), 254.

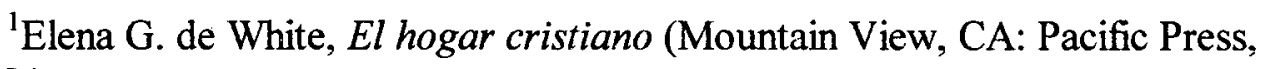

${ }^{2}$ Ibíd., 255.

${ }^{3}$ Elena G. de White, El evangelismo (Miami: Asociación Publicadora Interamericana, 1994), 255. 
de una reunión en la que su esposo predicó, visitó a Ella Belden con quien tuvo momentos de oración. Luego visitó a los esposos Salisbury quienes, debido a la visita, sintieron que el Señor les bendecía. Después visitó a unos ancianos, entre los cuales estaban los Hnos. Morse. Todos se gozaron de verla y fueron confortados y bendecidos. ${ }^{1}$

Los niños son parte importante de la familia. Para contribuir a que ellos crezcan afirmadọs, Elena de White recomienda que en cada sermón se les reserve "un pequeño rincón”. ${ }^{2}$ El pastor puede hacer provisión para ellos en los cultos de la iglesia.

Otra responsabilidad del pastor consiste en capacitar a los miembros de la iglesia como ganadores de almas. Con esta capacitación, "trabajarán con tanta diligencia que no tendrán tiempo ni disposición para debilitar las manos de sus hermanos". ${ }^{3} \mathrm{Al}$ cumplir con esta responsabilidad, el pastor ayuda a establecerlos en la fe, y a interesarlos en todo ramo de la obra. ${ }^{4}$

\section{El compañerismo}

Al llegar a la iglesia, los miembros nuevos necesitan encontrar un ambiente agradable donde el compañerismo y.la amistad predominen. Este trabajo no pertenece sólo al pastor. Aunque él haga su parte, los miembros de más experiencia deben tratar "con paciencia y ternura a los recién llegados a la fe.... Si los miembros de la iglesia

${ }^{1}$ Elena G. de White, Mensajes selectos, 3 vols. (Mountain View, CA: Pacific Press, 1984), 3:300, 301.

${ }^{2}$ Elena G. de White, Obreros evangélicos (Buenos Aires: Casa Editora Sudamericana, 1971), 220.

${ }^{3}$ Elena G. de White, Joyas de los testimonios, 3 vols. (Mountain View, CA: Pacific Press, 1971), 3:82, 83.

${ }^{4}$ White, El evangelismo, 276. 
descuidan este deber serán infieles al cometido que Dios les ha dado". ${ }^{1}$ Elena G. de White amonesta: "Los miembros de la familia del Señor deben ser prudentes y vigilantes y hacer todo lo posible para salvar a sus hermanos más débiles". ${ }^{2}$ Agrega: "El gran obstáculo para nuestro avance en este tiempo es el egoísmo que impide que los creyentes tengan verdadero compañerismo el uno con el otro". ${ }^{3}$

La iglesia necesita lideres "que rehúsen hablar palabras que debiliten la confianza de cualquier alma en la Palabra de Dios o que destruyan el compañerismo que debiera existir entre los que tienen la misma fe". ${ }^{4}$

Una manera de fomentar el compañerismo es mediante el trabajo misionero en equipo. Las almas son ricamente bendecidasy se alaba a Dios "por el privilegio de colaborar con él en su obra. Afirmó White: “Al dedicaros de todo corazón a la obra que debe realizarse entraréis en una relación de verdadero compañerismo con vuestros compañeros en la obra". 5

\section{El servicio misionero}

El servicio dado a otros es un antídoto efectivo para prevenir la apostasía en la iglesia y mantener la unidad entre los nuevos miembros. Dice White: "Cuando las almas

\footnotetext{
${ }^{1}$ Ibíd., 258.

${ }^{2}$ Elena G. de White, Cada dia con Dios (Mountain View, CA: Pacific Press, 1979), 148.

${ }^{3}$ Elena G. de White, Alza tus ojos (Buenos Aires: Casa Editora Sdamericana, 1982), 67.

${ }^{4}$ White, El evangelismo, 345.

${ }^{5}$ Ibíd., 468.
} 
se convierten, ponedlas al trabajo en seguida. ... La mejor medicina que podéis dar a una iglesia no es predicar o sermonear, sino planear trabajo para sus miembros". ${ }^{1}$

Los recién bautizados deben aprender que, "a fin de crecer en espiritualidad, deben llevar la carga que el Señor les ha impuesto, la carga de conducir almas a la verdad". ${ }^{2}$ Si los miembros nuevos no pueden realizar esta tarea, el pastor puede enseñarles mediante la visitación en sus hogares, orando con ellos y enseñándoles a “emplear sus talentos en dar la verdad a los que los rodean. Al trabajar así, tendrán la cooperación de los ángeles celestiales, y obtendrán una experiencia que aumentará su fe, y les dará una fuerte confianza en Dios".

El estudio de las Escrituras

"Los nuevos conversos a la verdad deben ser fielmente instruidos en el sencillo ‘Así dice el Señor'. La palabra del Dios ha de ser leída y explicada a ellos punto por punto", ya que "sin las Santas Escrituras, es imposible confirmar a los legos en la verdad". 5 Pero si la estudian con interés, y oran para comprenderla, verán nuevas bellezas en cada línea. Dios revelará una verdad preciosa tan claramente que la mente obtendrá un sincero placer y será una fiesta continua cuando sus confortantes y sublimes

${ }^{1}$ Ibíd., 261.

${ }^{2}$ White, Obreros evangélicos, 211.

${ }^{3}$ Ibid.

${ }^{4}$ White, El evangelismo, 227.

${ }^{5}$ Elena G. de White, El conflicto de los siglos (Mountain View, CA: Pacific Press, 1957), 288 
verdades sean reveladas. ${ }^{J}$

El conocimiento de las verdades bíblicas fundamentales es una arma poderosa contra la apostasía cuando la iglesia sea zarandeada. "El cristiano debe estar arraigado y fundado en la verdad para que pueda permanecer firme contra las tentaciones del enemigo. Debe experimentar una constante renovación de sus fuerzas, y debe retener firmemente la verdad biblica".2

El conocimiento de la palabra de Dios fortalece a los nuevos miembros. Este conocimiento debe ser impartido por los dirigentes, quienes con mucha oración, deben “mostrar a estos nuevos conversos cómo experimentar el poder de la verdad en el corazón". 3

Elena de White escribió también que "debe grabarse en la mente de todos los nuevos conversos, la verdad de que el conocimiento permanente puede adquirirse únicamente por la labor ferviente y el estudio perseverante". 4

Además de la Biblia, las publicaciones denominacionales contribuyen en la confirmación de los recién ingresados. Dice White que "los libros y periódicos son los medios dispuestos por el Señor para tener constantemente el mensaje para este tiempo delante de la gente. En cuanto a iluminar y confirmar a la gente en la verdad, las

${ }^{1}$ Elena G. de White, El ministerio pastoral (Silver Springs, MD: Asociación General de los Adventistas del Séptimo Dia, 1995), 217.

${ }^{2}$ White, El evangelismo, 165.

${ }^{3}$ White, Obreros evangélicos, 377, 378.

${ }^{4}$ Ibíd., 381. 
publicaciones harán una obra mayor que el solo ministerio de la palabra hablada"."

Los cultos y programas de la iglesia

Cuando un individuo se bautiza renuncia a costumbres y prácticas quedando un vacío en su vida. La iglesia puede llenar el vacío del nuevo miembro mediante programas y cultos atractivos. Cuando estos cultos, especialmente el de los sábados, incluyen sesiones de testimonios, las reuniones serán “como alimento a su debido tiempo, que reportará a todos los presentes nueva vida y renovado vigor".2

Elena de White dice que las reuniones de oración "deben ser los cultos más interesantes que se tengan". 3 Pero para que esto ocurra, "se deben hacer planes para dirigir las reuniones de manera que sean interesantes y atrayentes. La gente tiene hambre del pan de vida. Si lo encuentra en la reunión de oración, irá para recibirlo".4

Acerca de los programas de Escuela Sabática Elena, Elena de White dice que "puede ser un beneficio para otros, si en forma paciente, bondadosa e interesante le diera una pasada a la lección con aquellos que no toman interés en las cosas de Dios, e hiciera sencilla y definida su instrucción". 5

'Elena G. de White, El colportor evangélico (Buenos Aires: Casa Editora Sudamericana, 1978), 139, 140.

${ }^{2}$ Elena G. de White, El ministerio de la bondaa' (Buenos Aires: Casa Editora Sudamericana, 1963), 322.

${ }^{3}$ White, Joyas de los testimonios, 1:458.

${ }^{4}$ Ibíd.; en México se habla del "culto del miércoles".

${ }^{5}$ Elena G. de White, Consejos sobre la obra de la escuela sabática (Coral Gables, FL: Asociación Publicadora Interamericana, 1976), 90. 
Los grupos pequeños

Trabajar mediante grupos pequeños también ayuda a combatir la apostasía.

Elena de White dice que después de la expulsión de los discípulos de Jerusalén durante la persecución, el mensaje evangélico se difundió por las comarcas limítrofes de Palestina, y que en importantes poblaciones se constituyeron pequeñas compañías de creyentes. ${ }^{1}$

La misma autora comenta que el apóstol Pablo se sentía responsable del bienestar espiritual de los que se convertían al evangelio y deseaba su crecimiento en el conocimiento de Dios y de Jesucristo. Dice: "A menudo en su ministerio se encontraba con pequeños grupos de hombres y mujeres que amaban a Jesús, y se postraba en oración con ellos para pedir a Dios que les enseñara cómo mantener una relación vital con él". ${ }^{2}$ Cuando se retiraba a otro lugar, "suplicaba a Dios que los guardara del mal, y les ayudara. a ser misioneros fervientes y activos".3

* El trabajo en grupos pequeños no es una idea humana. Dice ella que "la formación de pequeños grupos como base de esfuerzo cristiano, es un plan que ha sido presentado ante mí por aquel que no puede equivocarse. Si hay un gran número de hermanos en la iglesia, organícense en grupos pequeños, para trabajar no solamente por los miembros de la iglesia, sino por los no creyentes también". ${ }^{4}$

${ }^{1}$ Elena G. de White, Los hechos de los apóstoles (Mountain View, CA: Pacific Press, 1977), 126.

${ }^{2}$ Ibíd., 213.

${ }^{3}$ Ibíd.

${ }^{4}$ White, El evangelismo, 89. 
El día y la hora para sesionar no son lo más importante. Ella declara: "Reúnanse pequeños grupos por la tarde, al mediodía o de mañana temprano para estudiar la Biblia. Dediquen tiempo a la oración para ser fortalecidos, alumbrados y santificados por el Espíritu Santo.... Si vosotros mismos abrís la puerta, recibiréis una gran bendición. Los ángeles de Dios estarán en vuestra asamblea. Seréis alimentados con las hojas del árbol de la vida"." "La bendición del Señor descenderá sobre los miembros de la iglesia que participan en la obra y cada día se reúnen en pequeños grupos para orar por su éxito ... y la obra del Señor será impulsadà hacia adelante". ${ }^{2}$

El trabajo con grupos pequeños es un excelente método para que los miembros de la iglesia crezcan espiritualmente, pues "en esos grupos pequeños Jesús está presente, se profundiza el amor por las almas en el corazón y el Espíritu despliega sus poderosas energías para que los agentes humanos puedan ejercitarse en la salvación de los perdidos". ${ }^{3}$

\section{La retención según otros autores}

Un término que la literatura utiliza en el contexto de la retención de miembros es "asimilación". Asimilación "es la tarea de trasladar a la persona desde el punto en el que descubre la existencia de la iglesia hasta el punto en que se transforma en asistente, y de allí a ser miembro activo de la iglesia". ${ }^{4}$ La capacidad de asimilación de los recién

\section{8), 92.}

${ }^{1}$ Elena G. de White, En lugares celestiales (Mountain View, CA: Pacific Press,

${ }^{2}$ White, El evangelismo, 86 .

${ }^{3}$ Elena G. de White, Exaltad a Jesús (Coral Gables, FL: Asociación Publicadora Interamericana, 1988), 352.

${ }^{4}$ Rick Warren, Una iglesia con propósito: Cómo crecer sin comprometer el mensaje y la misión, trad. Cecilia de Francesco (Miami: Vida, 1998), 320. 
llegados indica el bienestar de las iglesias. ${ }^{1}$

Varios estudios indican que la falta de un plan de asimilación de miembros produce apostasía. Esta apostasía se incrementó a partir de la década de los 70 en iglesias protestantes. Por ejemplo, la iglesia presbiteriana en los Estados Unidos perdió el 30 por ciento de su feligresía de 1960 a $1990 .^{2}$ Por otro lado, el Tabernáculo Metropolitano de la ciudad de Londres, en donde Spurgeon le predicaba hasta a veintitrés mil personas a principios del siglo XX, en 1972 sólo tenía 87 personas asistiendo al culto semanal. ${ }^{3}$

La iglesia adventista pierde miembros cada año. Según un estudio realizado por Roger L. Dudley, entre 40 y 50 por ciento de los adolescentes que se bautizan, abandonan la iglesia al llegar a los veinte años de edad. Esto lo califica este autor como una "hemorragia de proporciones épicas".

Hay iglesias que tratan de retener a los miembros recién ingresados mediante el cuidado de personas mayores. Sin embargo este método no siempre funciona debido a las diferencias que existen entre el recién ingresado y la persona que se le asigna para su cuidado.

Kurt W. Johnson menciona la experiencia de Cheryl, una joven de 22 años que él mismo bautizó a la cual se le asignó una dama de más de 60 años de edad para

'John S. Savage, "The Teflon Church", Leadership 11 (Otoño 1990): 30-37.

${ }^{2}$ Donald P. Smith, How to Attract and Keep Active Church Members (Louisville: Westminster/John Knox, 1992), 15.

${ }^{3}$ Glen Martin y Gary McIntosh, The Issachar Factor: Understanding Trends That Confront Your Church and Designing a Strategy for Success (Nashville: Broadman and Holman, 1993), 7.

${ }^{4}$ Roger L. Dudley, Why Our Teenagers Leave the Church (Hagerstown, MD: Review and Herald, 2000), 60. 
cuidarla. La dama estaba a su lado en todo momento y procuraba presentarla a otros miembros, pero nunca se produjeron relaciones más íntimas. La razón era que lo que Cheryl buscaba era sentir que formaba parte de una comunidad donde encontrara apoyo adecuado a sus necesidades. ${ }^{1}$

Para que el recién ingresado a la iglesia permanezca firme, debe crecer espiritualmente y contribuir para alcanzar a otros. Dice Philip G. Samaan que Jesús se preocupó porque sus discípulos reprodujeran su vida y su ministerio en otras personas. Es un círculo al que debe ingresar todo miembro de iglesia hasta que todos lleguen a ser discípulos de Cristo. El propósito de este crecimiento es llegar a ser como Cristo. ${ }^{2}$

La literatura relacionada con la retención y pérdida de miembros dice que hay razones por las cuales existe apostasía. Estas razones se presentan a continuación, seguidas por sugerencias para asimilar a los recién ingresados.

Razones por las que existe pérdida de miembros

Según Gordon Bruce Turner, un individuo es candidato a convertirse en apóstata cuando su asistencia a los cultos es irregular, cuando no se involucra en las actividades de la iglesia ni da apoyo financiero, o bien, cuando su actitud es negativa hacia la denominación o se avergüenza de identificarse con ella. Miembros que tienen estas características llevan una vida formalista y son superficiales en su experiencia espiritual.

\footnotetext{
${ }^{1}$ Kurt W. Johnson, Grupos pequeños para el tiempo del fin (Miami: Asociación Publicadora Interamericana, 1999), 53, 54.

${ }^{2}$ Philip G. Samaan, Christ's Way of Reaching People: The Fine Art of Relational Witnessing (Hagerstown, MD: Review and Herald, 1990), 125.
} 
Aunque son creyentes, no se sienten parte de la iglesia. ${ }^{1}$

Estos síntomas pueden ser producidos por no contextualizar el ministerio pastoral a las situaciones actuales de la iglesia, pues aunque el mundo ha revolucionado en otras áreas, el ministerio sigue empleando los mismos métodos. ${ }^{2}$ En ocasiones, también los pecados de los miembros ${ }^{3}$ hacen que éstos pierdan el interés en la iglesia, llevándolos a la apostasía.

Martin y McIntosh señalan que no atender las necesidades personales de los miembros, tanto materiales como espirituales, puede ser otro factor que contribuya a la apostasía. ${ }^{4}$ Pero la razón más señalada es la falta de integración en un grupo pequeño donde encuentren participación y amigos con quienes relacionarse. ${ }^{5}$ El recién ingresado a la iglesia debiera tener cinco amigos como promedio ${ }^{6}$ durante sus primeros seis meses, aunque James C. Bland dice que debiera tener siete. ${ }^{7}$

Por su parte Jolene L. Roehlkepartain reconoce que la falta de un ministerio pastoral en favor de la familia, especialmente enfocado hacia la juventud, coloca a los 3.

${ }^{1}$ Gordon Bruce Turner, Outside Looking In (Toronto: United Church, 1987), 2,

${ }^{2}$ Martin y McIntosh, 7.

${ }^{3}$ Smith, How to Attract and Keep Active Church Members, 15.

${ }^{4}$ Ibid.

${ }^{5}$ Lyle E. Schaller, Assimilating New Members (Nashville: Abingdon, 1978), 69, 70.

${ }^{6}$ Win Arn, The Church Growth Ratio Book (Pasadena: Church Growth, 1987), 23.

${ }^{7}$ James C. Bland, "How to Close the Back Door", Christianity Today, 17 enero 1986, 74 . 
miembros en riesgo de apostatar. ${ }^{1}$

También existe la transferencia de miembros de una iglesia a otra, sin embargo, esto no es necesariamente pérdida ya que los miembros sólo pasan a formar parte de otra congregación. ${ }^{2}$

En relación a los adolescentes y jóvenes, Dudley dice que llegan a la iglesia buscando sinceridad, un ambiente genuino y un significado para sus vidas. Buscan amor, aceptación y profundidad espiritual. Pero se confunden por la tensión que existe entre la doctrina del adventismo y la vida práctica de los miembros adultos. Se preguntan:

¿Cómo puede el adventismo ser verdad, cuando lo que experimentamos es alienación, irrelevancia, intolerancia y autojustificación?

Dudley asegura que los jóvenes no se van de la iglesia porque no crean en sus doctrinas o porque no estén seguros de que sea la iglesia verdadera. En su estudio obtuvo respuestas tales como, "yo sé que es la iglesia verdadera", "yo creo en las doctrinas de la iglesia cien por ciento" y "yo creo que es el remanente de Dios y quiero ser parte de él".

Estrategias que contribuyen a la retención de miembros

Las estrategias que se emplean para retener a los miembros de iglesia son varias.

Esta sección describe las más comunes: adecuación de los programas y cultos,

${ }^{1}$ Jolene L. Roehlkepartain, Youth Ministry: Its Impact on Church Growth (Loveland, CO: Group, 1989), 4; citado en Donald P. Smith, Empowering Ministry: Ways to Grow in Effectiveness (Louisville: Westminster/John Knox, 1996), 34, 35.

27.

${ }^{2}$ Lyle E. Schaller, The Small Church Is Different! (Nashville: Abingdon, 1982),

${ }^{3}$ Dudley, 62, 63 .

${ }^{4}$ Ibíd., 115. 
asimilación por medio de la amistad, la enseñanza de métodos de trabajo, cultivación de los roles ministeriales, períodos pastorales más largos, predicación bíblica y grupos pequeños.

\section{Programas adecuados}

Las iglesias son heterogéneas; es decir, sus miembros son diferentes unos a otros en sexo, ocupación, edad e intereses personales. Esta diferencia requiere una adecuación de programas y cultos para atender las necesidades más comunes. Un buen ejemplo de esta adecuación es lo que realiza una iglesia evangélica de Ocean View. Cada domingo de mañana se realizan tres cultos, el primero a las 8:00, que consta de un servicio popular para los jóvenes, quienes al igual que el predicador, asisten con ropa informal. Los cantos son alegres y acompañados con guitarras. El segundo culto, a las 9:30, es un culto tradicional; los himnos son cantados por un coro, las oraciones son formales, los cantos son de corte familiar; a este culto asisten las familias con sus hijos. A las 11:00 es el tercer culto que se realiza igual que el segundo pero con un servicio de comunión. ${ }^{1}$ Independientemente del estilo de culto, la adoración verdadera debe tomar en cuenta dos elementos básicos: Relación entre Dios y su pueblo y relación entre los miembros del pueblo de Dios. ${ }^{2}$

Según Hartman, en la organización de actividades en la iglesia debiera tomarse

${ }^{1}$ Smith, How to Attract and Keep Active Church Members, 23.

${ }^{2}$ Alberto Barrientos, Principios y alternativas del trabajo pastoral (Miami: Caribe, 1989), 254. 
en cuenta a los miembros que muestran más interés en ellas. ${ }^{1}$ Por ejemplo, si hay miembros interesados en el compañerismo, es mejor colocarlos como líderes de grupos pequeños; los que se interesan en el evangelismo, que participen en actividades misioneras; los que prefieren el estudio de las doctrinas, que dirijan estudios bíblicos o que prediquen. Por supuesto, hay miembros que pueden combinar dos o más de estas áreas. $^{2}$

Para optimizar los programas Smith insiste en identificar las necesidades de la iglesia. Esto se puede lograr mediante reuniones de miembros que tengan como propósito conocerse mutuamente. También se pueden identificar las necesidades de la iglesia mediante la visitación pastoral o aplicando encuestas acerca de las expectativas de los miembros en relación con programas de la iglesia.

Si los diáconos colaboran en la identificación de necesidades que los programas de la iglesia puedan atender, lo pueden hacer visitando a los nuevos miembros en sus hogares para discutir con ellos sobre las actividades y programas que más les interesan. ${ }^{3}$ Esta información también es útil para que el pastor sepa qué sermones predicar.

Los programas para jóvenes son una ayuda eficaz en la retención de miembros. Un estudio de veinte iglesias de rápido crecimiento reveló que cerca de tres cuartas partes de los miembros dijeron que el ministerio juvenil era muy importante en su continuo desenvolvimiento en la iglesia, mientras que el 68 por ciento aseguró que si no hubiera

\footnotetext{
'Warren J. Hartman, Membership Trends: A Study of Decline and Grow in the United Methodist Church, 1949-1975 (Nashville: Discipleship Resources, 1976), 46, 47. ${ }^{2}$ Ibíd.

${ }^{3}$ Smith, How to Attract and Keep Active Church Members, 32, 33.
} 
sido por el ministerio juvenil estarían fuera de la iglesia. ${ }^{1}$

Los programas de retención de jóvenes han dado resultados positivos. Un ejemplo es "Cristianos en servicio", practicado por la Suburban First Church. Este programa depende de un fuerte compañerismo entre jóvenes e incluye la atención a los adultos. Consiste en un proyecto misionero anual de verano en el cual jóvenes y adultos mantienen un equilibrio entre estudio, camaradería y servicio a la comunidad.

Para que sean efectivos los programas juveniles, Smith sugiere desarrollar un sistema de compañerismo entre los jóvenes sin descuidar la atención a los adultos. En la agenda de la iglesia debiera incluirse el servicio a la comunidad desempeñado con alegría. Debiera procurarse la participación de todos los miembros, incluyendo a los padres de los jóvenes que participan en el programa. Estos programas debieran tomar en cuenta los riesgos por los cuales pasa la juventud, tales como depresión, alcoholismo, drogadicción, problemas sexuales, entre otros. Ante estos riesgos los adolescentes son más vulnerables; por lo tanto, debiera tomarse en cuenta para orientarlos.

\section{Asimilación por medio de la amistad}

Una pregunta frecuente entre los recién ingresados es: ¿soy querido o apreciado en mi iglesia? Esta interrogante surge debido a que la gente puede ser alcanzada, bautizada y traída dentro de la iglesia pero no ser incorporada en los círculos de amigos existentes en la misma. ${ }^{2}$ Por lo tanto, es importante el fortalecimiento de las relaciones

${ }^{1}$ Smith, Empowering Ministry: Ways to Grow in Effectiveness, 35.

${ }^{2}$ Gary McIntosh y Glen Martín Finding Them, Keeping Them: Effective Strategies for Evangelism and Assimilation in the Local Church (Nashville: Broadman and Holman, 1992), 75-133. 
como parte del trabajo pastoral.'

La amistad incluye camaradería y comunión. Y esto es justamente la iglesia: una comunión de socios, ciudadanos del Reino de Dios. ${ }^{2}$ Las relaciones entre los hermanos de la iglesia debieran ser motivadas por el amor genuino y la ayuda mútua. José H. Prado, presenta algunas conclusiones de un análisis de la parábola del hijo pródigo. Escribe: "Ni la oración ni el apostolado, ni cosa alguna están por encima de atender al hermano semimuerto. El pecado del sacerdote y el levita no fue que oraran o dieran culto a Dios, sino que todo eso no los excusaba de asistir al moribundo". 3

La Iglesia Adventista de Chile ha manifestado preocupación por la creciente apostasía presentemente experimentada en sus filas. Para combatirla, el Ministerio de la Mujer implementó un plan denominado "Ministerio de conservación", el cual enfatiza el ministerio de la amistad como medio para retener a los miembros. Es un plan en el que la mujer tiene la principal participación. Consiste en fomentar las relaciones persona a persona y mediante grupos. Este plan involucra a los miembros de experiencia para que ayuden a retener a los miembros mediante las relaciones sociales. Con este proyecto esperan retener el 80 por ciento de las personas que ingresen a la iglesia, integrar a las clases postbautismales al 80 por ciento e integrar a los grupos pequeños al 90 por ciento de los recién bautizados.

${ }^{1}$ Thomas S. Rainer, High Expectations: The Remarkable Secret for Keeping People in Your Church (Nashville: Broadman and Holman, 1999), 5.

${ }^{2}$ Roy Alan Anderson, The Shepherd-Evangelist; His Life, Ministry, and Reward (Washington, DC: Review and Herald, 1950), 68. 1998), 98.

${ }^{3}$ José H. Prado Flores, Formación de discipulos (México, D. F.: Kerygma, 
Un objetivo del plan "Ministerio de conservación" consiste en hacer amistad enviando alguna tarjeta de saludos, regalando algún libro de interés, compartiendo recetas de cocina. También se sugiere intercambiar poemas, invitar a almorzar los sábados, recibir el sábado en familia, despedir el sábado juntas, orar juntas, visitar su casa, llamar por teléfono o introducir a los hermanos al grupo pequeño de su preferencia. ${ }^{1}$

\section{Enseñanza de métodos de trabajo}

La iglesia del Nuevo Testamento impactó al mundo a través de la experiencia de sus miembros y dirigentes. Éstos lideres "eran responsables principalmente de preparar a la congregación para el servicio productivo y para dar testimonio ante la gente con quien se relacionaban". ${ }^{2}$ Carlos Martín dice que el adiestramiento de los miembros para que trabajen a favor de otros es un medio efectivo para que permanezcan dentro de la iglesia. ${ }^{3}$

El rol básico del clérigo en el Nuevo Testamento consistía en la educación de los miembros y el establecimiento de células para atender la iglesia local. Dice Russell Burrill que únicamente cuando esto se aplique a la iglesia actual, estaremos recobrando el modelo de la iglesia del Nuevo Testamento. ${ }^{4}$

Un testimonio del beneficio de la enseñanza de métodos de trabajo es la

${ }^{1}$ Ministerio de la mujer de la Unión Chilena, "Proyecto: Ministerio de conservación, <http://www.adventistas.cl/minmuj.htm> (17 de julio de 2002).

${ }^{2}$ Rex D. Edwards, Cada creyente, un ministro (Silver Spring, MD: Asociación Ministerial, Asociación General de la Iglesia Adventista, 1999), 8.

${ }^{3}$ Carlos Martín, Cómo trastornar al mundo, trad. Rolando A. Itin (Buenos Aires: Casa Editora Sudamericana, 2000), 138.

${ }^{4}$ Russell C. Burrill, Recovering an Adventist Approach to the Life and Mission of the Local Church (Fallbrook, CA: Hart Research Center, 1998), 254. 
experiencia de Juan Wesley. En 1739, a pesar de que muchas congregaciones no tenían un edificio para adorar, Juan Wesley inició un programa para discipular a sus convertidos. Con muchas limitaciones y escasez de materiales formó un ejército de predicadores laicos y de cristianos férvorosos que se convirtieron en la fuerza moral más grande de su tiempo. Como resultado de este trabajo las iglesias cristianas revivieron. ${ }^{1}$

Melvin J. Steinborn, basado en la experiencia de la iglesia del Nuevo Testamento, dice que existen tres equipadores disponibles para instruir a la iglesia. Los pastores-maestros aparecen en Efesios 4:11, 12, donde tienen la tarea de "perfeccionar a los santos para la edificación del cuerpo de Cristo”. El Espíritu Santo proporciona el poder (Hch. 1:8) y guía a toda verdad (Juan 16:13). Finalmente las Escrituras sirven para "instruir en justicia, a fin de que el hombre de Dios sea perfecto, enteramente preparado para toda buena obra" $(2$ Ti. $2: 16,17) .^{2}$

La iglesia fue establecida para preparar a los santos para la obra del ministerio (Ef. 4:12). Los pastores tienen esta responsabilidad: "preparar y adiestrar a las tropas para la batalla que pelean". ${ }^{3}$

Después ser instruidos para el trabajo evangelístico, los miembros deben ser enviados a trabajar. Rick Warren ha descubierto que "la salud o la fuerza de una iglesia se mide por la cantidad de personas que envia y no por la cantidad de personas que acomoda". 4

${ }^{\mathrm{I}} \mathrm{G}$. William Schweer, La evangelización personal para hoy (El Paso: Casa Bautista, 1992), 250.

${ }^{2}$ Melvin J. Steinbron, Can the Pastor Do It Alone? A Model for Preparing Lay People for Lay Pastoring (Ventura: Regal, 1987), 93, 94.

${ }^{3}$ Edwards, 14.

${ }^{4}$ Warren, 37. 


\section{Períodos pastorales largos}

Existen denominaciones cuyos pastorados son muy cortos. Un pastor permanece en su iglesia sólo unos pocos años o aun meses y luego es trasladado. De esta manera, la iglesia no siempre logra continuidad en el programa de trabajo y se afecta la asimilación de miembros nuevos. Una iglesia con un elevado índice de asimilación tiene en promedio pastorados de 9,8 años, mientras que las iglesias con poca asimilación tienen pastorados de cuatro años, en promedio. Un pastorado largo es productivo debido a que se puede llevar un mejor control en la atención pastoral, el diezmo, la asistencia a la iglesia, la participación en las actividades y la lealtad al cuerpo de doctrinas. ${ }^{1}$

Por supuesto, "un pastorado largo no garantiza que una iglesia crecerá, pero el cambio frecuente de pastores garantiza que una iglesia no crecerá. . . . Los pastorados largos hacen que sean posibles las relaciones profundas, de confianza y de cuidado de los unos hacia los otros".2

\section{Predicación bíblica efectiva}

"Puesto que en la sabiduría de Dios, el mundo no ha conocido a Dios mediante la sabiduría, a Dios le pareció bien salvar a los creyentes por la locura de la predicación" (1 Co. 1:21). Estas palabras de Pablo son contundentes. Una de las actividades más importantes en el ministerio es la predicación.

La locura de la predicación "es el medio designado por Dios para la salvación de

\footnotetext{
${ }^{1}$ Rainer, 13.

${ }^{2}$ Warren, 35.
} 
las almas"; por lo tanto, "el mundo no llegará a convertirse por el don de lenguas, o por obra de milagros, sino por la predicación de Cristo crucificado".2 Si éste es el método de Dios para la salvación de las almas, debe serlo también para retenerlas: Según Charles Bradford, la predicación "es la función ministerial que más que ninguna otra le da al predicador autoridad, estatura y reputación". ${ }^{3}$ No obstante, debido a la escasez de predicación con mayor contenido bíblico, a una pobre exposición de la Palabra y a la baja calidad de los sermones, muchos jóvenes, especialmente universitarios, están abandonando la iglesia. Charles Bradford agrega que "los jóvenes graduados de licenciatura que han abandonado la iglesia, frecuentemente culparon a la calidad de la predicación adventista y la falta de oportunidades para servir en la organización local de la iglesia". ${ }^{4}$ Otros jóvenes se quejan de tener que escuchar sermones que suenan como repeticiones. ${ }^{5}$

La predicación era un asunto importante en tiempos del Nuevo Testamento para la confirmación de los creyentes. Pablo dice que los creyentes eran hechos "firmes según mi evangelio y la predicación de Jesucristo" (1 Co. 16:25).

'Elena G. de White, Testimonies for the Church, 9 vols. (Mountain View, CA: Pacific Press, 1948), 5:300.

${ }^{2}$ Elena G. de White, Testimonios para los ministros (Mountain View, CA: Pacific Press, 1977), 424.

${ }^{3}$ Charles Bradford, Predicación para estos tiempos (Hagerstown, MD: Review and Herald, s.f.), 9.

${ }^{4}$ Ibid., 8.

${ }^{5}$ Ibíd. 
Para fortalecer la asimilación de miembros, el predicador debiera predicar bíblicamente. Pablo le llama "predicación de Jesucristo" (Ro. 16:25) y "predicación del evangelio" (Ga. 2:7), en tanto que Lucas dice que "Pablo se dedicó enteramente a la predicación de la Palabra" (Hch. 18:5). El error de muchos pastores es dar pan endurecido a la iglesia en vez de la Palabra de Dios. "Tienen educación universitaria, pero esos pastores no alimentan a la grey de Dios".

Se debe contextualizar el mensaje. Bradford dice que "el sermón tradicional no ha pasado de moda, pero la terminología y los clichés deberían dar lugar a una retórica más contemporánea". ${ }^{2}$ Por esto el predicador debe estar familiarizado con su época.

Al hablar de los hijos de Isacar la Biblia dice que eran "entendidos en los tiempos, y que sabían lo que Israel debía hacer" (1 Cr. 12:32). Entendían "el significado de lo que acontecía y podían dar un consejo oportuno". ${ }^{3}$ Eso debiera hacer el predicador moderno: "preocuparse por las personas y sus necesidades reales". 4

\section{La autoridad espiritual de los líderes}

Stephen B. Bond define la autoridad espiritual como el "poder de Dios sobre la vida del líder, con la cual llega a ser una influencia para sus seguidores para cumplir el

\footnotetext{
${ }^{1}$ White, El ministerio pastoral, 216.

${ }^{2}$ Bradford, 8 .

3“Entendidos en los tiempos", [1Cr. 12:32], Comentario bíblico adventista
} $(C B A)$, ed. F. D. Nichol, trad. V. E. Ampuero Matta (Boise: Publicaciones Interamericanas, 1978-1990), 3:166.

${ }^{4}$ Bradford, 18. 
propósito de Dios". 1

Para lograr autoridad, Gene Getz dice que el líder debe vivir una vida ejemplar delante de cristianos y no cristianos. Esta vida ejemplar se relaciona con los aspectos morales (1 Ti. 3:7), sociales y espirituales. Además, el líder debe aprender a comunicar y escuchar en vez de argumentar. En cuanto a su familia, debe tener buena relación con sus hijos y con su esposa. Si llena estas expectativas, entonces podrá dar dirección a la iglesia. ${ }^{2}$ Según Mel Lawrenz, es mediante el ejemplo del lider como las personas reciben atención espiritual efectiva, pues la dirección es tan buena como la fidelidad, la sabiduría y la integridad del líder. ${ }^{3}$

Aunque parece excesivo lo que se espera del líder, el consejo que da Pablo a Timoteo es similar: "Sé ejemplo de los creyentes en palabra, en conducta, amor, espíritu, fe y pureza" (1Ti. 4:12). Además debía dedicarse a "la exhortación y la enseñanza" (4:15), teniendo cuidado de sí mismo y de la doctrina (4:16).

El estilo del liderazgo del pastor puede ayudar a la retención de sus miembros o a producir un efecto contrario, que produzca desánimo y debilitamiento espiritual. ${ }^{4}$

\section{Grupos pequeños}

El ministerio de los grupos pequeños es un método que se empleó durante los

\footnotetext{
${ }^{1}$ Stephen B. Bond, Spiritual Authority, God's Way of Growing Leaders (Joplin, MO: College Press, 1995), 12.

${ }^{2}$ Gene Getz, “Becoming A Spiritually Mature Leader", en Leaders on Leadership, ed. George Barna (Ventura: Regal, 1997), 87. $2000), 97$.

${ }^{3}$ Mel Lawrenz, The Dynamics of Spiritual Formation (Grand Rapids: Baker,

${ }^{4}$ Smith, Empowering Ministry, 41.
} 
tres primeros siglos de la era cristiana. Como resultado, la iglesia, en ese período, creció sustancialmente con buena salud espiritual. ${ }^{1}$ Russell Burrill afirma que la historia de la iglesia primitiva enseña que en tiempos de persecución los cristianos pudieron sobrevivir cuando se apoyaban en las relaciones de un grupo pequeño, y que como adventistas, debiéramos fortalecer el desarrollo de relaciones interpersonales en grupos pequeños para fortalecer la fe en estos momentos finales de la historia. ${ }^{2}$

Los grupos pequeños ayudan a la retención de miembros lo mismo que las iglesias pequeñas. Estas iglesias pueden ser dirigidas por laicos y fomentar la participación de los miembros en los programas y actividades. También puede fomentarse la visitación entre hermanos, para que todos se conozcan. En los grupos pequeños las reuniones sociales ocupan un lugar importante, teniendo como consecuencia miembros espiritualmente sanos. ${ }^{3}$ Tanto la iglesia como el grupo pequeño pueden integrar en su programa: oración, alabanza, proclamación y propagación. ${ }^{4}$

Los grupos pequeños son perfectos para crear relaciones más estrechas entre sus miembros cuando son conformados por afinidad. Una práctica efectiva es reunirse en los hogares, ya que los grupos se pueden multiplicar sin tener límites geográficos. A la vez,

${ }^{1}$ Russell Burrill, The Revolutionized Church of the 21st Century (Fallbrook: Hart Research Center, 1997), 91, 92.

${ }^{2}$ Ibíd., 94

${ }^{3}$ Schaller, The Small Church Is Different! (Nashville: Abingdon, 1982), 27-40.

${ }^{4}$ Larry L. Lewis, Manual para plantar iglesias, trad. Edgar Morales (El Paso: Casa Bautista, 1997), 95-106. 
hogar donde se reúne el grupo se beneficia fortaleciendo sus relaciones. ${ }^{1}$

Kurt W. Johnson aconseja que, para que un grupo pequeño funcione, debiera crearse un ambiente de camaradería con el mínimo de reglas. El pastor de la iglesia debiera hacer de los grupos pequeños lo más importante de su ministerio. ${ }^{2}$

Otro nombre para designar a los grupos pequeños es koinonia. Koinonia es un término griego que se ha traducido como: comunidad, participación, compartir y comunión. Implica compartir los bienes materiales, compartir el ministerio y ser compañeros en el evangelio. La koinonía está basada en la realidad espiritual de una conexión entre los creyentes y Cristo (1 Jn. 1:3, 6-7). ${ }^{3}$ Según Kurt Johnson las bases de una buena koinonia son cuatro:

Un liderazgo sólido. El líder debe ser capaz de establecer una agenda e innovar actividades con el propósito de que los miembros sean correctamente dirigidos hacia un objetivo.

Una buena teologia. Una teología fundamentada en la Biblia establece equilibrio en la conducta de los miembros de la koinonía sin llegar al fanatismo pero tampoco al secularismo de las actividades. La calidad de la teología define la calidad de liderazgo y, por lo tanto, la calidad de la koinonía.

Enfoque. Las actividades deben tener un objetivo. Por ejemplo, un grupo que se reúne con regularidad para fomentar el crecimiento espiritual, tendrá actividades que incluyan la oración, el estudio de la Biblia y la adoración.

\footnotetext{
${ }^{1}$ Warren, 337.

${ }^{2}$ Johnson, 163-165.

${ }^{3}$ Lawrenz, 99.
} 
Tiempo para programar. Un buen programa de actividades no surge de forma improvisada. Es necesario dedicarle tiempo. Sólo así puede ser atractivo a la vez que habrá coordinación con los miembros y líderes de otras koinonias. El resultado es confianza en el líder y confianza en los miembros. ${ }^{1}$

Como es de notarse, la literatura proporciona ideas para la retención de miembros, lo cual hace evidente la necesidad de un plan para evitar apostasía en la iglesia. Según el estudio realizado en la Iglesia Adventista de Pueblo Nuevo, Chiapas, para la elaboración de este proyecto, las necesidades y problemas más comunes que producen apostasía son semejantes a las que se mencionan en este capitulo.

\footnotetext{
'Ibíd., 107-111.
} 


\section{CAPÍTULO III}

\section{LA IGLESIA DE PUEBLO NUEVO}

Para una mejor comprensión del desarrollo de la Iglesia Adventista del Séptimo Día de Pueblo Nuevo Solistahuacán, Chiapas, es necesario un análisis de su entorno geográfico, cultural, religioso y demográfico. También es importante conocer la historia de la iglesia, sus programas de evangelismo, de retención de miembros, así como las principales actividades a las cuales se dedican sus miembros.

\section{Contexto geográfico}

Pueblo Nuevo Solistahuacán es uno de los 118 municipios del estado libre y soberano de Chiapas, México con una población mayormente indígena. Enclavado en las montañas donde empieza la región de los “altos de Chiapas", está a $17^{\circ} 09^{\prime}$ latitud Norte y $92^{\circ} 54^{\prime}$ latitud Oeste y a 1.720 metros sobre el nivel del mar. En la época prehispánica pertenecía a la región zoque, pero entre los años 1486 y 1502 sufrió la influencia del dialecto náhuatl, de ahí que el nombre Solistahuacán en éste dialecto, significa "lugar de los que tienen armas de pedernal". ${ }^{1}$

Varios años después de la colonia, el 5 de mayo de 1909, fue inaugurada la calle principal del poblado. El 23 de noviembre de 1922 fue ascendido a municipio de segunda

${ }^{1}$ Consejo Estatal Técnico de la Educación, Antología: Cosas y casos de mi tierra (Tuxtla Gutiérrez, Chiapas: Consejo Estatal, 2000), 211. 
Categoría. ${ }^{1}$ Este status lo conserva hasta hoy.

\section{Contexto cultural}

Pueblo Nuevo es uno de los municipios con más alto grado de marginación del estado de Chiapas. Existe un alto rezago en áreas como la educación, la economía y en fuentes de trabajo. Un estudio realizado por la Presidencia Municipal clasificó a la población entre los niveles "alto" y "muy alto" de marginación. ${ }^{2}$

Después delespañol, predomina el tzotzil, segundo grupo étnico en Chiapas después del tzeltal. La economía está basada en la agricultura, con cultivos de maíz, café y hortalizas, aunque también son importantes los trabajos textiles y la ganadería. ${ }^{3}$

El 52 por ciento de la población es mestiza y el 48 por ciento es de descendencia de tres grupos indígenas: tzotzil, chamula y tzotzil San Andrés. Todos ellos conservan sus tradiciones así como su identidad indígena. ${ }^{4}$

Los grupos indígenas todavía visten sus trajes típicos, costumbre que hace más marcada la diferencia entre los que hablan el dialecto y los que hablan el español. Esta diferencia también es común en la iglesia adventista de la región.

\section{Contexto religioso}

La comunidad de Pueblo Nuevo está ubicada donde comienza la zona conocida

$$
{ }^{1} \text { Ibíd., } 211 .
$$

${ }^{2}$ José Luis Bautista Bautista, Plan de desarrollo municipal, 2002-2004 (Pueblo Nuevo Solistahuacán, Chiapas: Presidencia municipal, 2002), 13-17.

${ }^{3}$ Jorge A. Orozco Zuarth y Marco A. Orozco Zuarth, Geohistoria de Chiapas (México, D. F.: Offset California, 1996), 20.

${ }^{4}$ Bautista, 11. 
como los "altos de Chiapas". En esta zona hay intolerancia religiosa desde que el Ejército Zapatista de Liberación Nacional (EZLN) inició la guerrilla el día primero de enero de 1994. Sin embargo, a pesar de su ubicación, en Pueblo Nuevo existe más libertad que en otras partes de "los altos de Chiapas" para profesar la religión que el individuo desee.

El padre Felipe Arizmendi Ezquivel, obispo de San Cristóbal de las Casas, presentó un discurso en el foro sobre "Tolerancia y diversidad religiosa," en abril de 2001. En este discurso expresa la preocupación de los católicos chiapanecos por la pérdida de miembros. Dijo que "hace tiempo, en Chiapas la religión católica era casi la única existente, como sucedía en la mayor parte del país". ${ }^{1}$ Pero ahora el panorama es distinto. La iglesia católica pierde feligreses cada año mientras que las iglesias evangélicas los ganan. Sin embargo, en su mismo discurso hizo notar que en el año 2000 el porcentaje de evangélicos y protestantes disminuyó en relación con las décadas anteriores.

En 1980 había 76,9 por ciento de católicos, 11,5 por ciento de evangélicos, 10,0 por ciento sin religión y 1,6 por ciento de otras no registradas. En 1990 había 67,6 por ciento de católicos ( 9,3 por ciento menos que la década anterior), 16,3 por ciento de evangélicos (4,8 por ciento más que la década anterior); 12,7 por ciento sin religión y 3,4 por ciento de otras religiones. Para el año 2000 había 64,46 por ciento de católicos $(3,14$ por ciento menos que la década anterior), 14,50 de evangélicos (1,8 por ciento menos en relación con la década anterior), 12,16 por ciento sin religión y 0,79 por ciento de otras

${ }^{1}$ Felipe Arizmendi Esquivel, "La pluralidad religiosa, riqueza cultural de Chiapas", <http://www.laneta.apc.org/curiasc/foro20-21 Abril.htm> (15 de junio de 2002). 
religiones. ${ }^{1}$

Es evidente que existe pérdida de miembros tanto entre católicos como evangélicos. De 1990 en adelante, proliferaron grupos independientes que no pueden ser clasificados como religiones. Tampoco se pueden identificar como evangélicos o protestantes, sin embargo, como supuestamente utilizan la Biblia como base de sus enseñanzas pero no están registrados en la Secretaría de Gobernación, aparecen como "bíblicos no evangélicos". Estos representan 8,09 por ciento de la población de Chiapas. ${ }^{2}$ Los Adventistas del Séptimo Día están considerados dentro de los evangélicos. La figura 1 muestra el crecimiento de las religiones en Chiapas.

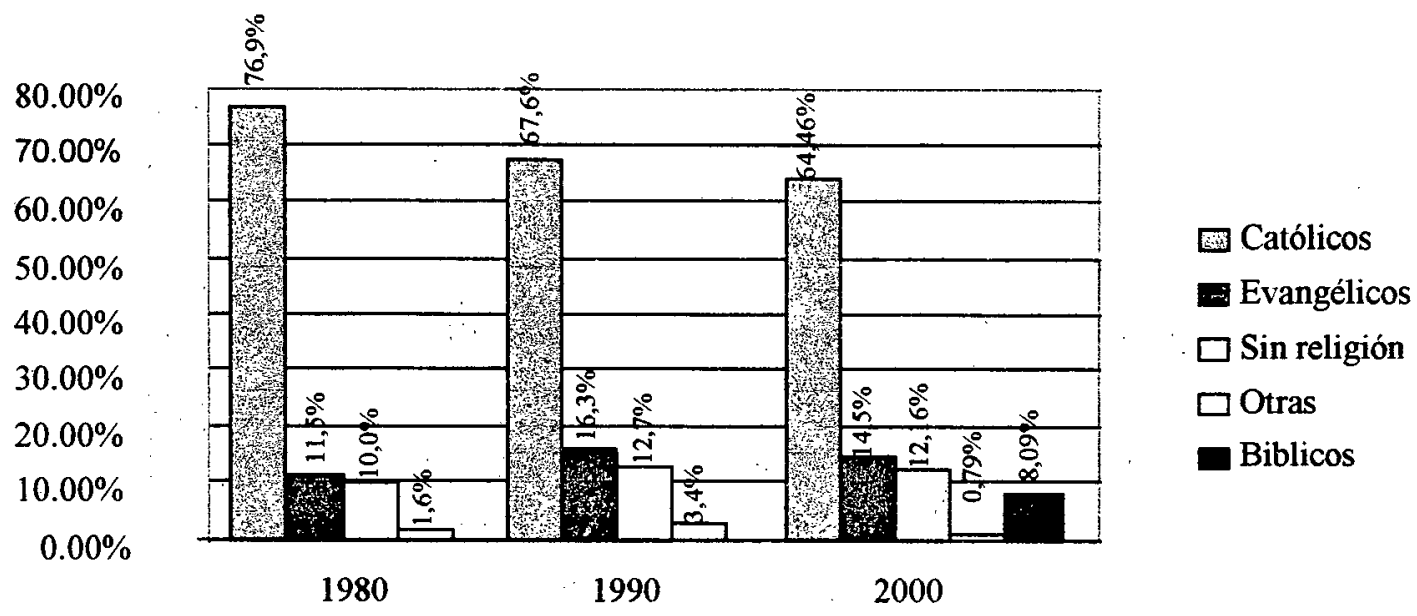

Fig. 1. Comparación del porcentaje de crecimiento/disminución entre católicos, evangélicos, sin religión, otras y bíblicos.

Pueblo Nuevo se caracteriza por una tradición religiosa arraigada desde sus

${ }^{1}$ Ibíd.

${ }^{2}$ Ibid. 
propios inicios. Esta tradición consiste en la celebración de días especiales de fiestas y de culto. El 15 de enero es el día del Señor de las Esquipulas; del 25 al 28 de febrero se festeja a San Leonardo; el 3 de mayo a la Santa Cruz; del 27 de mayo al 1 de junio se celebra la fiesta de San Bartolomé; el 25 de septiembre, a la Virgen de la Merced; del 7 al 10 de octubre, a San Dionisio (la fiesta principal del pueblo); el 30 de noviembre, a San Pedro y el 12 de diciembre a la Virgen de Guadalupe. Además se conmemora la Semana Santa, el Día de los muertos, la Navidad y el Día de los Santos Reyes. ${ }^{1}$

La religión indígena se caracterizan por el sincretismo, una mezcla de catolicismo con elementos culturales y culto a divinidades aborígenes. Los tzotziles y los tzeltales conciben al mundo como un todo y lo llaman cielo-tierra (vinajel-balamil). La vida se desarrolla en la superficie del cielo y la tierra, mientras que la vida extraordinaria, como la de los sueños, existe en el "otro cielo-tierra". Sólo los curanderos pueden verlo. ${ }^{2}$

Según Gabriela Rebolledo Hernández los indígenas tzotziles creen en cuatro formas fundamentales de la divinidad: los totilme'iletik (padresmadres) son dioses ancestrales apreciados como indígenas que viven en los lugares sagrados, otorgan el sustento y recompensan o castigan. Creen que un individuo posee un ch'ulel o "alma", compuesta de trece partes. Cuando un tzotzil rompe con el orden establecido, los totilme'iletik lo castigan con el daño a su ch'ulel. En este caso, es necesaria la intervención del ilol para su recuperación. Cada individuo posee un ch'ulel o "espíritu animal acompañante" que es cuidado por los totilme'iletik.

En Pueblo Nuevo predomina la Iglesia Católica con todo el sincretismo teológico que la población practica. También existen otros grupos religiosos, tales como

\footnotetext{
${ }^{1}$ Bautista, 10.

${ }^{2}$ Gabriela Robledo Hernández, "Pueblos indígenas de México", $<\mathrm{http} / / /$ www.ini.gob.mx/monografias/tzotziles.html> (13 de junio de 2002).

${ }^{3}$ Ibíd.
} 
Pentecostales y Testigos de Jehová, pero representan una minoría. En este ambiente de actividad y sincretismo religioso, la Iglesia Adventista del Séptimo Día existe desde 1959, cuando llegaron los primeros misioneros estudiantes de teología del entonces Colegio Linda Vista.

\section{Contexto demográfico}

En el año 2000 todo el municipio de Solistahuacán al cual pertenece Pueblo Nuevo, tenía una población de 24,561 habitantes, de los cuales 49,21 por ciento eran hombres y 50,79 por ciento mujeres. ${ }^{1}$ La población habla mayormente dialectos, ${ }^{2}$ siendo el tzotzil uno de los principales ${ }^{3}$ y representando un 39,15 por ciento de la población total. Actualmente la población de Pueblo Nuevo es de 4,996 habitantes. ${ }^{4}$

No existe control de natalidad, por lo cual las familias por lo general son numerosas. Hay familias que tienen hasta catorce hijos. ${ }^{5}$

\section{Contexto económico}

Sólo el 28,28 por ciento de la población de Pueblo Nuevo es considerada económicamente activa. De éste total, 69,45 por ciento se dedica a la agricultura y

\footnotetext{
${ }^{\mathrm{I} B a u t i s t a,} 37$.

${ }^{2}$ Instituto Nacional de Estadística, Geografia e Informática, "Ejidos y comunidades agrarias, según actividad principal, uso del suelo y parcelamiento por municipios con $30 \%$ y más de población indígena", <http://www.ciesas.edu.mx/ bibdf/ini/estatal/chiapas/13_anexo.html> (13 de junio de 2002).

${ }^{3}$ Ibíd.

${ }^{4}$ Bautista, 39.

${ }^{5}$ Nicolás Pérez, pastor jubilado de la Sección Norte de Chiapas y pionero de la Iglesia Adventista del Séptimo Día en Pueblo Nuevo Solistahuacán, Chiapas, entrevista por el autor, Pueblo Nuevo Solistahuacán, Chiapas, 10 de junio de 2002.
} 
ganadería, 4,12 por ciento a la industria, 8,45 por ciento al comercio y servicios y 17,98 por ciento a actividades no especificadas. La actividad agrícola predominante es la siembra y cosecha del café, maíz, frijol, papa y repollo. La ganadería es actividad de menor importancia, habiendo producción de ganado bovino para carne y leche; porcino y ovino para carne, y aves de corral productoras de huevo. En el sector industrial la actividad predominante es la artesanal, se producen textiles en las colonias Lotes y Rincón Chamula. En el sector forestal se produce anualmente un total de 40 metros cúbicos de pino y 380 metros de guanacaste. ${ }^{1}$

\section{Historia y desarrollo de la Iglesia Adventista}

La obra de la Iglesia Adventista del Séptimo Día empezó en Pueblo Nuevo Solistahuacán en 1959. Su inicio fue el resultado del trabajo misionero de los alumnos del Colegio Linda Vista, hoy Universidad Linda Vista. Esta universidad está ubicada a cuatro kilómetros sobre la carretera que lleva a Tuxtla Gutiérrez. En aquel tiempo las clases de teología se ofrecían junto con los estudios de secundaria, de manera que quienes trabajaron en Pueblo Nuevo eran muy jóvenes y algunos todavía adolescentes.

Entre los pioneros se encuentran los pastores Abdón Castellanos, Isaías Hernández y Nicolás Pérez. Como es una zona donde se produce flor de alcatraz, ellos iban para admirar los jardines de las casas y comprar flores. Después establecían un contacto amistoso y dejaban un folleto. Al siguiente sábado volvían para ver la impresión que había causado en la familia. Una vez despertado el interés, ofrecían cursos bíblicos mediante los cuales enseñaban la doctrina adventista. Al principio todos

\footnotetext{
1"Pueblo Nuevo Solistahuacán" <http://www.elchiapaneco.com.mx/V/ munis/pueblo\%20nuevo\%20solistauacan/> (13 de junio de 2002).
} 
los intereses eran indígenas hablantes del dialecto tzotzil. Sólo los hombres hablaban un poco de español, así que con ellos empezaron a estudiar.

En 1959 David Silva, profesor del Colegio Linda Vista, dirigió una campaña de evangelismo en el templo del Colegio. Como resultado Pablo López Pérez y Catalina Pérez Díaz iniciaron el estudio de la doctrina adventista asesorados por Isaías Hernández, Abdón Castellanos y Daniel Barreto, estudiantes del Colegio. El pastor Samuel Guízar los bautizó el 24 de junio de 1961. Estos dos hermanos viven todavía como esposos y dirigen una Escuela Sabática filial en su propia casa. ${ }^{2}$

La iglesia empezó como una Escuela Sabática filial y a partir de 1969 comenzó a funcionar como iglesia organizada. Con el tiempo el español fue predominando hasta que en 1981 la iglesia se dividió en dos grupos, los que hablaban tzotzil y los que hablaban español. El primero formó la iglesia que hoy es conocida como San Lorenzo, nombre de la colonia donde construyó su templo. El segundo permaneció en el lugar donde originalmente había empezado. A este grupo de le conoce como Iglesia Central. ${ }^{3}$

Actualmente existen nueve iglesias y congregaciones en la zona de Pueblo Nuevo. Las iglesias donde se habla el idioma español son: La iglesia central (Pueblo Nuevo I), Pueblo Nuevo III, Los Pinos, La Loma y. Yerba Buena. De dialecto tzotzil son: San Lorenzo (Pueblo Nuevo II), Los Lotes, San José Rincón y Rincón Chamula. La iglesia de la Universidad Linda Vista, a través de la Escuela de Teología sigue apoyando

${ }^{1}$ Pérez, entrevista.

${ }^{2}$ Pablo López Pérez, primer adventista del séptimo día en Pueblo Nuevo Solistahuacán, Chiapas, entrevista por el autor, Pueblo Nuevo Solistahuacán, Chiapas, 10 de junio de 2002.

${ }^{3}$ Pérez, entrevista. 
con el evangelismo en esta zona y sus alrededores.

Trabajo evangelístico

La iglesia creció y se fortaleció por el trabajo evangelístico de los alumnos del Colegio Linda Vista, siendo "La voz de la juventud" el principal manual sobre doctrinas que utilizaban.

Las campañas de evangelismo al inicio de la obra en este lugar duraban un mínimo de un mes. Iniciaban con temas introductorios sobre la familia y la salud para después presentar temas doctrinales. Eran precedidas por campañas de barrio dirigidas por miembros voluntarios. Este trabajo era reforzado por la visitación personal casa por casa. El pastor Nicolás Pérez testifica que este método ayudó a que la gente entendiera bien la doctrina, evitando apostasias. La prueba está, dice, en que "los miembros viejos que iniciaron la obra todavía están adentro".'

\section{Programas de retención}

Desde la organización de la iglesia central de Pueblo Nuevo no existen programas de retención de miembros. Lo que los pioneros hicieron fue afirmar la doctrina mediante el estudio sistemático en las casas de los interesados. No los bautizaban hasta asegurarse de que habían estudiado en forma completa un manual de estudios bíblicos. De esta manera, dice el pastor Nicolás Pérez, tenían buen fundamento bíblico y estaban comprometidos con Dios y con la iglesia. Después se les capacitaba para trabajar por otros. ${ }^{2}$

${ }^{1}$ Ibíd.

${ }^{2}$ Ibíd. 
En una entrevista realizada al pastor Rolando Márquez, secretario de la Sección Norte de Chiapas, me informé que la iglesia tiene, en el presente, actividades que contribuyen a la retención de miembros, tales como los campamentos del ministerio juvenil, semanas especiales dedicadas a la educación, la mayordomía, y otras. También, afirma este pastor, que se intenta retener a los miembros mediante el plan denominado "el hermano mayor".

El plan del hermano mayor consiste en asignar a cada recién bautizado un miembro de más experiencia y madurez espiritual para que lo anime, que le aclare las dudas que surjan en relación con la doctrina y los programas y cultos de la iglesia. Incluye la visitación en su hogar para orar con él y estudiar juntos la lección de Escuela Sabática.

Según el pastor Nicolás Pérez, este plan no ha dado los resultados esperados y es afectado por campañas de evangelismo de apenas una semana, en las cuales no se predican temas doctrinales. Quienes se bautizan como resultado de estas campaña no tienen la preparación adecuada ni tiempo suficiente para establecer amistades y pronto dejan de asistir. ${ }^{2}$ El capítulo 4 estudia la situación de la iglesia y el problema que experimenta con la retención de miembros.

\footnotetext{
'Rolando Márquez, Secretario de la Sección Norte de Chiapas durante el período 1998-2002, con sede en Pichucalco, Chiapas, entrevista por el autor, Pichucalco, Chiapas, 15 de abril de 2002.

${ }^{2}$ Pérez, entrevista.
} 


\section{CAPÍTULO IV}

\section{LA APOSTASÍA EN LA IGLESIA \\ DE PUEBLO NUEVO}

Este capítulo presenta un estudio general de la Iglesia Adventista del Séptimo Día de Pueblo Nuevo Solistahuacán, Chiapas. El propósito es conocer su situación durante los últimos diez años con respecto al crecimiento, la asimilación y la apostasía de miembros.

La información que se presenta proviene de los registros del Departamento de Secretaría de la Sección Norte de Chiapas y de los libros de Secretaría de la propia iglesia. Además, ofrece los resultados de una encuesta aplicada a miembros de iglesia que asisten regularmente, a pastores de la Sección Norte de Chiapas y a personas de la comunidad que abandonaron la fe.

\section{Situación general de la iglesia}

Durante los últimos diez años la Iglesia Adventista de Pueblo Nuevo Solistahuacán, Chiapas, ha tenido seis pastores con un promedio de 1,6 años de servicio ministerial. Sin embargo, dos de estos pastores no completaron el año. Ellos fueron: Eliseo García y Herasto Martínez, quienes trabajaron unos pocos meses durante los años 1991 y 1996 respectivamente. Según entrevistas con miembros de la congregación, la iglesia perdió continuidad en sus planes de trabajo debido al frecuente movimiento 
pastoral. La tabla 1 muestra el movimiento de pastores de la iglesia:

\section{TABLA 1}

\section{MOVIMIENTO DE PASTORES EN LA IGLESIA DE PUEBLO NUEVO}

\begin{tabular}{|l|l|}
\hline Período de ministerio & Nombre del pastor \\
\hline $1989-1990$ & Luis Morales J. \\
\hline 1991 & Eliseo García \\
\hline $1992-1995$ & Félix González \\
\hline 1996 & Herasto Martínez \\
\hline $1997-1999$ & Elías Escolástico \\
\hline 2000 & Elías Ávalos \\
\hline
\end{tabular}

Para el 31 de diciembre de 1989, según el registro local, la iglesia contaba con una feligresía de 165 miembros. Entre 1990 y 1999 se añadieron 291 personas, llegando a 456 miembros para fines de 1999. Esto representa un crecimiento de un 176,36 por ciento. Pero los libros de Secretaría y de la Junta Administrativa de la iglesia en septiembre de 1999, indican la separación de 244 miembros, de los cuales, 192 fueron por apostasía, o sea un 116,33 por ciento en relación con los miembros existentes en 1989. Esto da un crecimiento real de 99 miembros (60 por ciento) (ver figura 2).

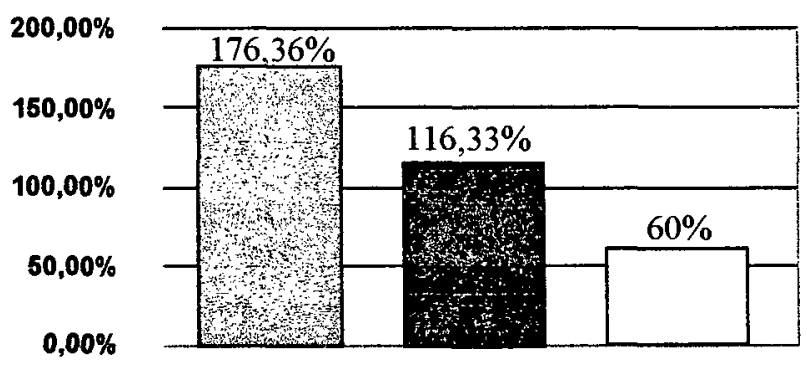

$\square$ Crecimiento en 10 años, $\mathrm{N}=291$

E Apostasia en 10 años, $\mathrm{N}=192$

$\square$ Crecimiento real en 10 años, $\mathrm{N}=99$

Fig. 2. Crecimiento/decrecimiento de 1989 a 1999 sin incluir muerte y transferencia de miembros. 
Las razones de la separación fueron: por muerte 14 miembros $(5,73$ por ciento en relación con los que ingresaron de 1990 a 1999); por carta 38 miembros (15,57 por ciento); y por apostasía 192 miembros, (78,68 por ciento). Ver figura 3.

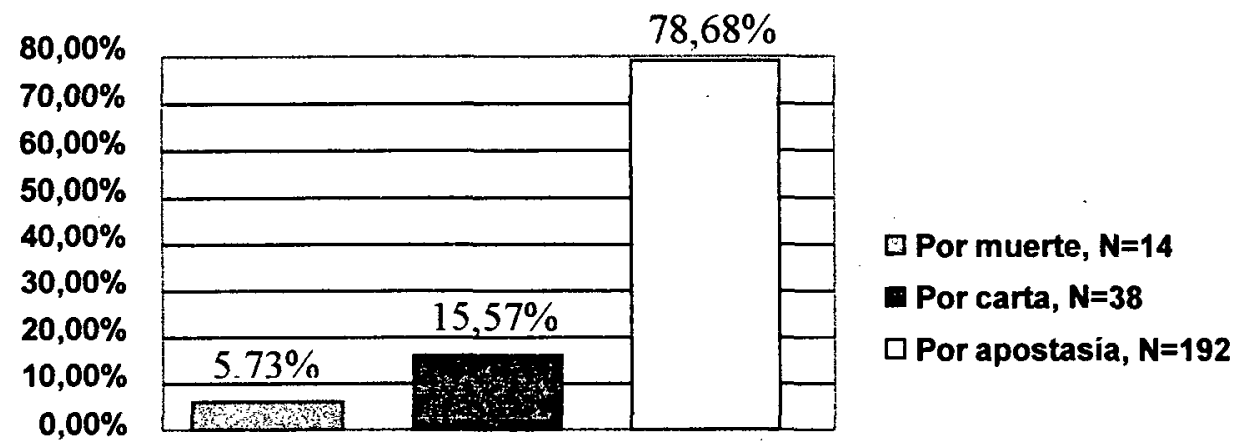

Fig. 3. Porcentaje de miembros separados por muerte, por carta y por apostasía de 1990 a 1999.

Debido a la decisión de la iglesia de borrar a estos miembros, de los 456 miembros registrados en los libros, sólo quedaron 215 , sin incluir a los 38 miembros que se trasladaron a otras iglesias por carta. De este modo el crecimiento real de la iglesia fue sólo de 28,48 por ciento en diez años. Esto da como promedio un crecimiento real de 2,84 por ciento anual

El porcentaje de pérdida de miembros por apostasía en este período de diez años fue de 42,1 por ciento tomando en cuenta la feligresía total hasta 1999. Pero si la pérdida se calcula en relación con los que entraron a la iglesia en el mismo período, el porcentaje sería de 65,97 por ciento.

La iglesia tuvo bautismos cada año. También tuvo reuniones de celebración en las cuales se reconoció el trabajo evangelístico de la hermandad. Sin embargo, el porcentaje de crecimiento por bautismos fue neutralizado por la apostasía de miembros. 
Por ejemplo, la tabla 2 muestra que en 1992 se bautizaron ocho personas, pero abandonaron la iglesia otras ocho, lo que dio un crecimiento de 0,0 por ciento en dicho año.

TABLA 2

COMPARACIÓN DE BAUTISMOS Y APOSTASÍA DESDE 1990 HASTA1999

\begin{tabular}{|c|c|c|c|c|c|c|c|}
\hline \multirow[t]{2}{*}{ Año } & \multirow[t]{2}{*}{$\begin{array}{l}\text { Miem- } \\
\text { bros } \\
\mathrm{N}\end{array}$} & \multicolumn{2}{|c|}{$\begin{array}{l}\text { Número de } \\
\text { bautizados y \% de } \\
\text { crecimiento en } \\
\text { relación con la } \\
\text { feligresía del año } \\
\quad \text { anterior } \\
\end{array}$} & \multicolumn{2}{|c|}{$\begin{array}{l}\text { Apóstatas y \% de } \\
\text { pérdida en relación } \\
\text { con los bautizados } \\
\text { en el año }\end{array}$} & \multicolumn{2}{|c|}{$\begin{array}{l}\text { Miembros que aún } \\
\text { permanecen y } \% \text { de } \\
\text { retención en relación } \\
\text { con los que entraron } \\
\text { en el año }\end{array}$} \\
\hline & & $\mathrm{N}$ & $\%$ & $\mathrm{~N}$ & $\%$ & $\mathrm{~N}$ & $\%$ \\
\hline 1989 & 165 & & & & & & \\
\hline 1990 & 176 & 11 & 6,66 & 4 & 36,36 & 7 & 63,64 \\
\hline 1991 & 188 & 12 & 6,81 & 0 & 0,0 & 12 & 100 \\
\hline 1992 & 212 & 8 & 4,25 & 8 & 100 & 0 & 0,0 \\
\hline 1993 & 236 & 24 & 11,32 & 9 & 37,5 & 15 & 62,5 \\
\hline 1994 & 247 & 11 & 4,66 & 6 & 54,54 & 5 & 45,46 \\
\hline 1995 & 306 & 59 & 23,88 & 10 & 16,94 & 49 & 83,96 \\
\hline 1996 & 342 & 36 & 11,76 & 12 & 33,33 & 24 & 66,67 \\
\hline 1997 & 382 & 31 & 9,06 & 11 & 35,48 & 20 & 64,52 \\
\hline 1998 & 422 & 40 & 10,47 & 14 & 35,0 & 26 & 65,0 \\
\hline 1999 & 456 & 34 & 8,05 & 29 & 86,29 & 5 & 14,70 \\
\hline TOTALES & 456 & 291 & 63,81 & 192 & 65,97 & 99 & 34,03 \\
\hline
\end{tabular}

\section{Encuesta}

Para conocer las razones de apostasía en ésta iglesia, se aplicó una encuesta a cuatro grupos de personas. Éstos fueron: miembros activos entre 9 y 30 años de edad, miembros activos mayores de 30 años de edad, apóstatas de diferentes edades y pastores que trabajan en la Sección Norte de Chiapas. 
La encuesta contenía las siguientes seis preguntas para solicitar información general y para descubrir alguna correlación con la apostasía.

1. ¿A qué edad fue bautizado?

2. ¿Fue presionado por algún laico o pastor para ser bautizado?

3. ¿Ha tenido cargos en la iglesia?

4. ¿Asiste regularmente a los cultos?

5. ¿Participa activamente en los programas de la iglesia?

6. ¿Cuánto tiempo hace que no asiste a la iglesia?

Además, la encuesta contenía 15 variables que sirvieron para identificar las razones de apostasía (ver apéndice A). Estas fueron:

1. Falta de compañerismo con los miembros

2. Cultos que no satisfacen las expectativas

3. Presión de familiares no adventistas

4. Problemas para guardar el sábado

5. Conflictos con otros miembros

6. Base doctrinal débil

7. Falta de participación en actividades misioneras

8. Injusticias dentro de la iglesia

9. Vida devocional pobre

10. Falta de visitación pastoral

11. Pecados personales

12. Problemas familiares (con la esposa, el esposo o los hijos)

13. Hábitos no vencidos 
14. Por no adaptarse al estilo de vida adventista

15. Por darles responsabilidades prematuramente

Para su aplicación se utilizó la escala de Likertt (respuestas de 1 a 5) donde 1 era muy en desacuerdo, 2 en desacuerdo, 3 neutral, 4 de acuerdo y 5 muy de acuerdo.

\section{Respuestas}

El Análisis de las encuestas se hizo de acuerdo a los grupos encuestados. El primero fue el de los miembros jóvenes.

\section{Miembros activos de 9 a 30 años de edad}

Se escogió este parámetro de edades debido a que en el Sur de México la costumbre es que entre los 9 y 10 años de edad la persona ya puede ser aceptada como miembro de iglesia, y los 30 años, porque dentro de estos límites se encuentra la mayor parte de la feligresía.

De los 80 encuestados, el promedio de edad a la que fueron bautizados fue de 14,5 años. Un 70 por ciento ( 56 personas) fue bautizado entre los 9 y 15 años, mientras que un 21,25 por ciento ( 17 personas) fue bautizado entre los 16 y 20 años y el 8,75 por ciento ( 7 personas) fue bautizado entre los 21 y 30 años. Esto se observa en la figura 4.

Con respecto a si fueron presionados o no para ser bautizados, los resultados fueron los siguientes: El 10 por ciento (8 personas) indicó que fue presionado para ser bautizado, mientras que el 90 por ciento (72 personas) lo hizo voluntariamente. Ver figura 5 . 


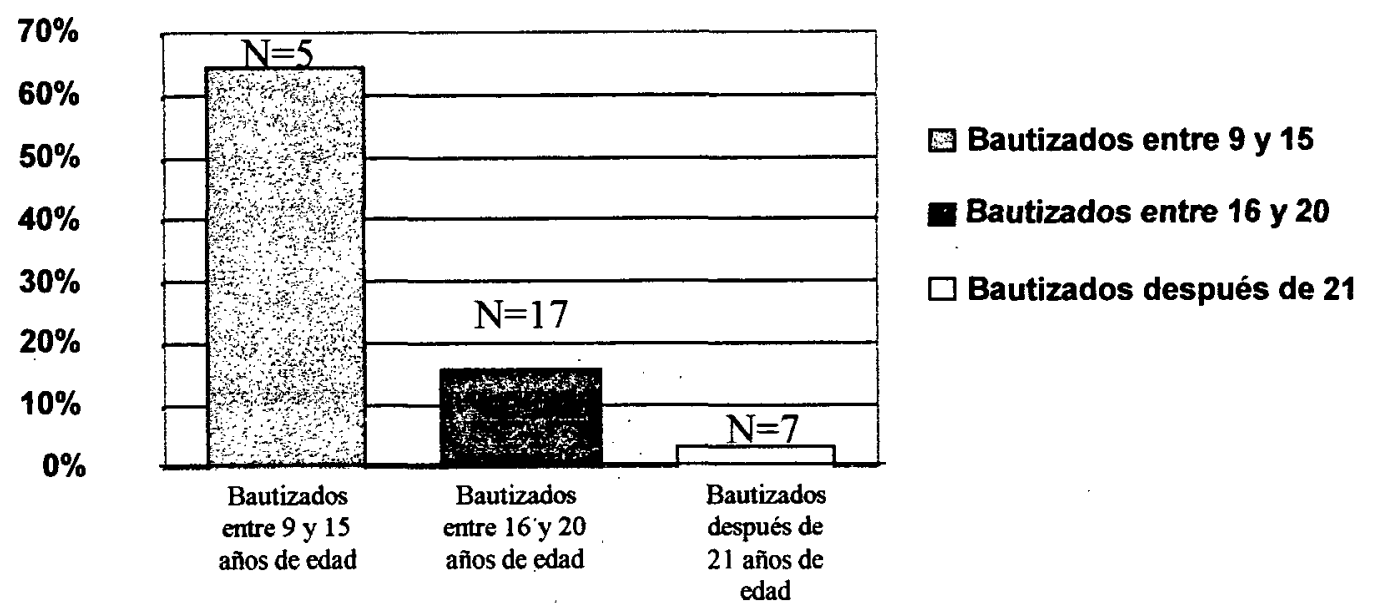

Fig. 4. Comparación de los porcentajes de miembros bautizados entre 9 y 15 años de edad, 16 y 20 años y bautizados después de los 21 .

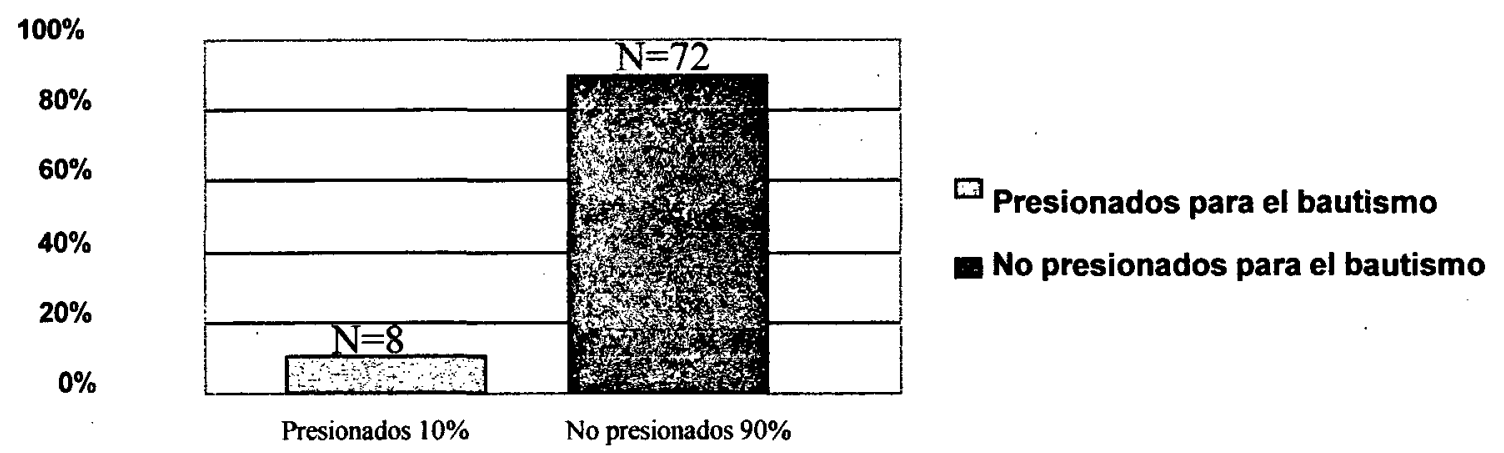

Fig. 5. Comparación de los miembros activos de hasta 30 años de edad que fueron presionados para ser bautizados y los que se bautizaron voluntariamente.

En relación con su vida activa dentro de la iglesia, el 10 por ciento ( 8 personas) no ha tenido ningún cargo, mientras que el 90 por ciento ( 72 personas) sí los ha tenido. El 93,75 por ciento ( 75 personas) asiste regularmente a la iglesia, mientras que el 6,25 por ciento (5 personas) no asiste. El 88,75 por ciento ( 71 personas) participa activamente en actividades, en tanto que el 11,25 por ciento ( 9 personas) no lo hace (Ver figura 6). Este resultado indica que por lo general los miembros que ingresan a la iglesia entre los 9 
y 15 años de edad lo hacen voluntariamente y se involucran en actividades que favorecen su asimilación.
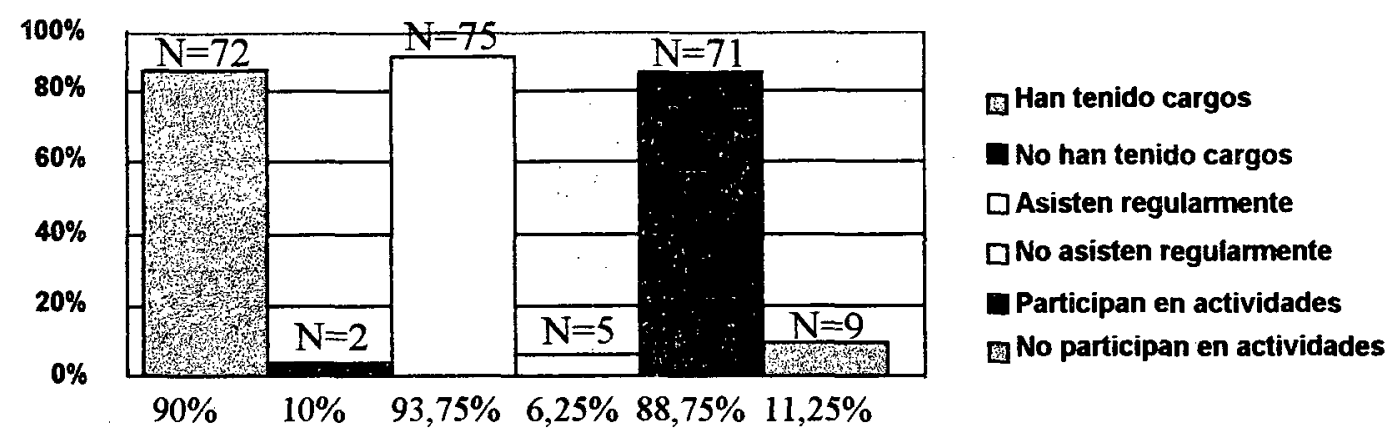

Fig. 6. Comparación entre los miembros de iglesia de 9 a 30 años de edad que tienen y que no tienen cargos, que asisten y que no asisten regularmente y que participan y no participan en actividades en la iglesia.

En el análisis realizado a los que fueron presionados para el bautismo se encontró el siguiente resultado: el 75 por ciento (6 personas) no ha tenido cargos en la iglesia; el 65,5 por ciento ( 5 personas) no asiste con regularidad y el 87,5 por ciento ( 7 personas) no participa en actividades (ver figura 7).

Esta comparación indica que los que son presionados para ser bautizados pueden convertirse en candidatos para salir por la puerta trasera de la iglesia, mientras que los que lo hacen voluntariamente tienden a permanecer en ella.

Con respecto a las 15 variables que se analizaron para descubrir razones de apostasía, según la escala de Likert, cada una podía recibir una respuesta desde 1 hasta 5 . Para obtener resultados mediante una vía más rápida, se sumaron las respuestas de cada variable y el resultado se dividió entre el total de personas encuestadas. Las fracciones de cada resultado que llegaron hasta " 5 " se interpretaron como con tendencia hacia el 
número inmediato inferior. Las fracciones de ",6" en adelante se interpretaron como con tendencia hacia el número inmediato superior (la tabla 3 muestra los resultados).

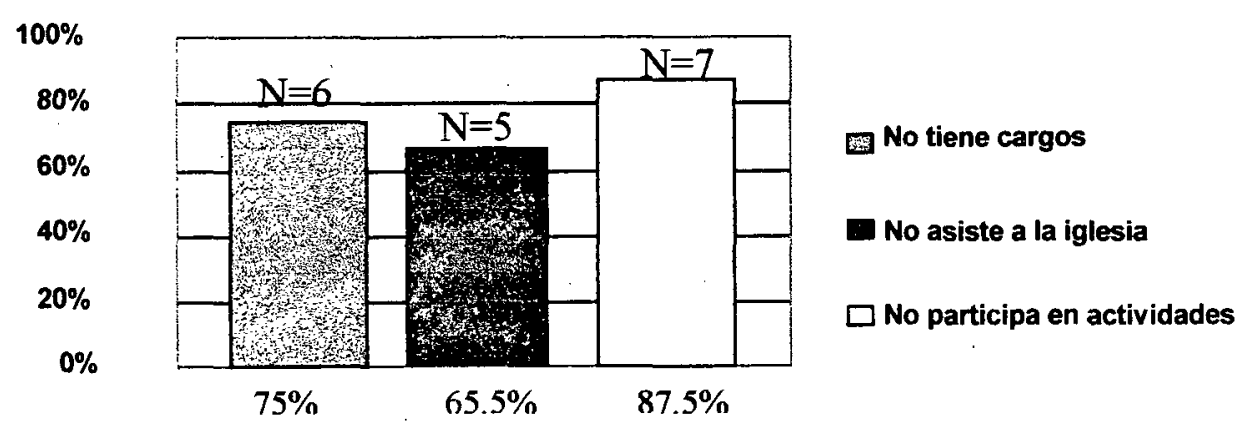

Fig. 7. Comparación de los presionados para el bautismo con su actividad en la iglesia: Cuántos no tienen cargos, cuántos no asisten a la iglesia y cuántos no participan en actividades.

Como es de notarse, las cinco variables que obtuvieron mayor incidencia fueron: vida devocional pobre, falta de compañerismo con los miembros, falta de visitación pastoral, hábitos no vencidos y conflictos con otros miembros (ver tabla 4). 
TABLA 3

RESULTADO Y TENDENCIA DE LAS VARIABLES QUE SE SUGIRIERON PARA DESCUBRIR RAZONES DE APOSTASÍA ENTRE MIEMBROS ACTIVOS DE 9 A 30 AÑOS DE EDAD

\begin{tabular}{|l|c|l|}
\hline Variable & Resultado & Tendencia \\
\hline Vida devocional pobre & 4,15 & De acuerdo \\
\hline Falta de compañerismo con los miembros & 3,82 & De acuerdo \\
\hline Falta de visitación pastoral & 3,81 & De acuerdo \\
\hline Pecados personales & 3,76 & De acuerdo \\
\hline Hábitos no vencidos & 3,63 & De acuerdo \\
\hline Conflictos con otros miembros & 3,62 & De acuerdo \\
\hline Conflictos con otros miembros & 3,62 & De acuerdo \\
\hline Falta de participación en actividades misioneras & 3,61 & De acuerdo \\
\hline Base doctrinal débil & 3,51 & De acuerdo \\
\hline Problemas familiares & 3,47 & De acuerdo \\
\hline Falta de adaptación al estilo de vida adventista & 3,38 & Neutral \\
\hline Cultos que no satisfacen las expectativas & 3,37 & Neutral \\
\hline Injusticias dentro de la iglesia & 3,16 & Neutral \\
\hline Problemas para guardar el sábado & 3,3 & Neutral \\
\hline Responsabilidades prematuras & 3,03 & Neutral \\
\hline Presión de familiares no adventistas & 3,01 & Neutral \\
\hline
\end{tabular}

TABLA 4

PRINCIPALES RAZONES DE APOSTASÍA SEGÚN MIEMBROS ACTIVOS DE 9 A 30 AÑOS DE EDAD

\begin{tabular}{|l|c|l|}
\hline Variable & Resultado & Tendencia \\
\hline Vida devocional pobre & 4,15 & De acuerdo \\
\hline Falta de compañerismo con los miembros & 3,82 & De acuerdo \\
\hline Falta de visitación pastoral & 3,81 & De acuerdo \\
\hline Hábitos no vencidos & 3,63 & De acuerdo \\
\hline Conflictos con otros miembros & 3,62 & De acuerdo \\
\hline
\end{tabular}


Miembros activos de más de 30 años de edad

De los 25 encuestados un 32 por ciento ( 8 personas) fue bautizado entre los 9 y 15 años, mientras que un 12 por ciento ( 3 personas) fue bautizado entre los 16 y 20 años y un 56 por ciento (14 personas) lo hizo cuando eran mayores de 21 años. La edad promedio de bautismo fue de 23 años (ver figura 8 ).

En el primer grupo se pudieron encuestar 80 personas, en el segundo sólo 25 , lo cual indica que hay mayor recepción al evangelio y menor riesgo de apostasía cuando el bautismo ocurre en la adolescencia que cuando ocurre en la juventud. Es importante, por lo tanto, que la iglesia establezca planes definidos para evangelizar y bautizar adolescentes.

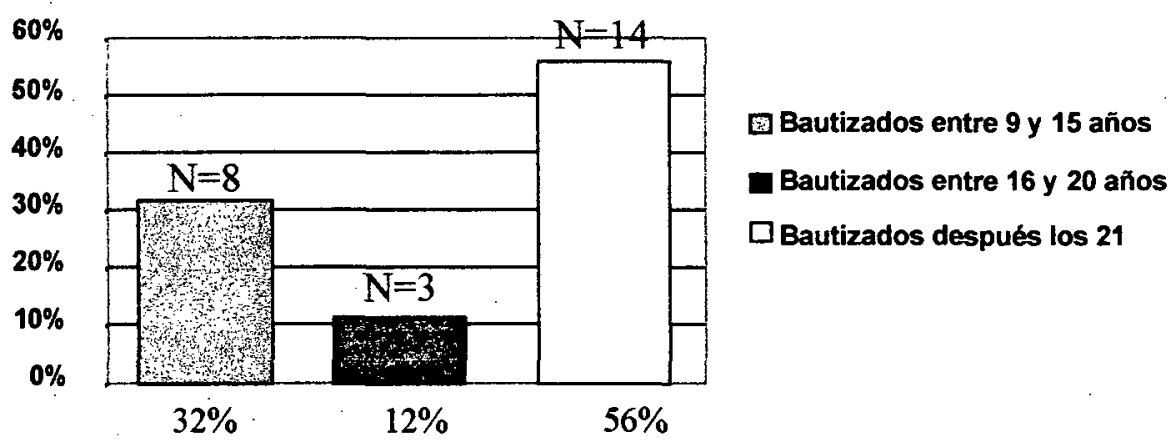

Fig. 8. Comparación de los miembros activos de más de 30 años de edad que fueron bautizados entre lo 9 y 15 años, 16 y 20 y después de los 21 años.

El 4 por ciento (1 persona) fue presionado para ser bautizado, mientras que el 96 por ciento ( 24 personas) se bautizó voluntariamente. Todos han tenido cargos, asisten con regularidad a la iglesia y participan activamente en todos los programas. La 
evidencia del estudio indica que ser bautizados voluntariamente contribuye a que las personas permanezcan en la iglesia.

Las razones por las cuales los miembros abandonan la iglesia, según las

respuestas a las 15 variables se muestran en la tabla 5 . En la tabla 6 se muestran las cinco razones más fuertes para dejar la iglesia. Se nota que, al igual que los más jóvenes, los adultos dieron como primera razón una vida devocional pobre.

\section{TABLA 5}

RESULTADO Y TENDENCIA DE LAS VARIABLES QUE SE SUGIRIERON PARA DESCUBRIR RAZONES DE APOSTASÍA ENTRE MIEMBROS ACTIVOS MAYORES DE 30 AÑOS DE EDAD

\begin{tabular}{|l|l|l|}
\hline Variable & Resultado & Tendencia \\
\hline Vida devocional pobre & 4,2 & De acuerdo \\
\hline Falta de visitación pastoral & 4,12 & De acuerdo \\
\hline Pecados personales & 3,88 & De acuerdo \\
\hline Conflictos con otros miembros & 3,84 & De acuerdo \\
\hline Problemas familiares & 3,72 & De acuerdo \\
\hline Falta de participación en actividades misioneras & 3,64 & De acuerdo \\
\hline Cultos que no satisfacen las expectativas & 3,52 & De acuerdo \\
\hline Problemas para guardar el sábado & 3,44 & Neutral \\
\hline Falta de compañerismo con los miembros & 3,4 & Neutral \\
\hline Base doctrinal débil & 3,28 & Neutral \\
\hline Injusticias dentro de la iglesia & 2,96 & Neutral \\
\hline Presión de familiares no adventistas & 2,6 & Neutral \\
\hline Hábitos no vencidos & 4 & De acuerdo \\
\hline Falta de adaptación al estilo de vida adventista & 3,6 & De acuerdo \\
\hline Responsabilidades prematuras & 3,28 & Neutral \\
\hline
\end{tabular}


TABLA 6

PRINCIPALES RAZONES DE APOSTASÍA SEGÚN MIEMBROS ACTIVOS DE MÁS DE 30 AÑOS DE EDAD

\begin{tabular}{|l|l|l|}
\hline Variable & Resultado & Tendencia \\
\hline Vida devocional pobre & 4,2 & De acuerdo \\
\hline Falta de visitación pastoral & 4,12 & De acuerdo \\
\hline Hábitos no vencidos & 4 & De acuerdo \\
\hline Conflictos con otros miembros & 3,84 & De acuerdo \\
\hline Problemas familiares & 3,72 & De acuerdo \\
\hline
\end{tabular}

\section{Apóstatas}

Fue más difícil conseguir la participación de personas que han abandonado la iglesia. Sin embargo, los que participaron, aportaron los siguientes resultados: 14,28 por ciento ( 6 personas) fue presionado para el bautismo mientras que el 85,72 por ciento ( 36 personas) lo hizo voluntariamente. El promedio de edad a la que fueron bautizados fue de 16 años. Un 57,14 por ciento ( 24 personas) fue bautizado entre los 9 y 15 años de edad, mientras que un 21,42 por ciento ( 9 personas) lo hizo entre los 16 y 20 años. El mismo porcentaje fue bautizado después de los 21 . Esto se observa en la figura 9 .

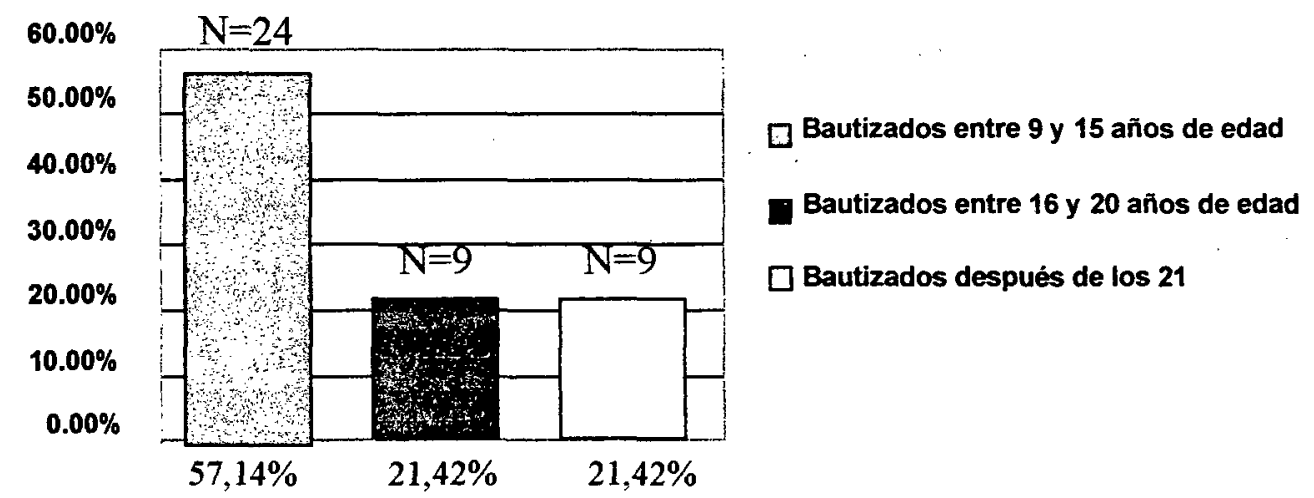

Fig. 9. Comparación de apóstatas que fueron bautizados entre 9 y 15,16 y 20 y después de los 21 años de edad. 
De los 42 encuestados, un 23,8 por ciento (diez personas) tuvo cargos en la iglesia, mientras que el 76,2 por ciento ( 32 personas) no los tuvieron. Actualmente ninguno asiste a iglesia ni participa en las actividades.

En la comparación de los tres primeros grupos encuestados (de 9 a 30 años de edad, mayores de 30 años y apóstatas), el resultado es que un mayor porcentaje de apóstatas fue presionado para el bautismo, según se muestra en la tabla 7.

\section{TABLA 7}

COMPARACIÓN DE PERSONAS PRESIONADAS PARA EL BAUTISMO SEGÚN GRUPOS ENCUESTADOS

\begin{tabular}{|l|c|c|}
\hline Grupo encuestado & $\mathrm{N}=$ & $\%$ \\
\hline De 9 a 30 años de edad & 8 & 10,0 \\
\hline Mayores de 30 años de edad & 1 & 4,0 \\
\hline Apóstatas & 6 & 14,28 \\
\hline
\end{tabular}

La vida activa dentro de la iglesia es importante, pues de las personas que abandonaron la iglesia, el 23,8 por ciento eran activas mientras que el 76,2 por ciento no lo era. Del grupo encuestado de 9 a 30 años de edad, el 90,0 por ciento era activo y 10,0 por ciento no lo era. Este es el grupo al cual pertenece la mayor cantidad de miembros que aún están dentro de la iglesia. Del grupo formado por mayores de 30 años, el 100 por ciento es activo. Este grupo tiene menor riesgo de apostasía. La tabla 8 muestra la comparación. 
TABLA 8

COMPARACIÓN DE LA ACTIVIDAD EN LA IGLESIA DE

LOS GRUPOS DE APÓSTATAS 9 A 30 AÑOS DE EDAD

Y MAYORES DE 30 AÑOS

\begin{tabular}{|l|c|c|}
\hline Grupo encuestado & $\%$ de activos & $\%$ de inactivos \\
\hline Apóstatas & 23,8 & 76,2 \\
\hline De 9 a 30 años de edad & 90,0 & 10,0 \\
\hline Mayores de 30 años & 100 & 0,0 \\
\hline
\end{tabular}

Las razones por las cuales los miembros abandonan la iglesia, según los

apóstatas, son muy similares al consenso de los dos grupos anteriores. Los resultados se muestran en la tabla 9.

TABLA 9

RESULTADO Y TENDENCIA DE LAS VARIABLES QUE SE SUGIRIERON PARA DESCUBRIR RAZONES DE APOSTASÍA ENTRE APÓSTATAS

\begin{tabular}{|l|c|l|}
\hline Variable & Resultado & Tendencia \\
\hline Vida devocional pobre & 3,73 & De acuerdo \\
\hline Conflictos con otros miembros & 3,61 & De acuerdo \\
\hline Falta de visitación pastoral & 3,59 & De acuerdo \\
\hline Pecados personales & 3,57 & De acuerdo \\
\hline Falta de adaptación al estilo de vida adventista & 3,57 & De acuerdo \\
\hline Falta de compañerismo con los miembros & 3,54 & De acuerdo \\
\hline Injusticias dentro de la iglesia & 3,42 & Neutral \\
\hline Hábitos no vencidos & 3,40 & Neutral \\
\hline Falta de participación en actividades misioneras & 3,38 & Neutral \\
\hline Problemas para guardar el sábado & 3,33 & Neutral \\
\hline Problemas familiares & 3,33 & Neutral \\
\hline Base doctrinal débil & 3,16 & Neutral \\
\hline Cultos que no satisfacen las expectativas & 3,14 & Neutral \\
\hline Responsabilidades prematuras en la iglesia & 3,14 & Neutral \\
\hline Presión de familiares no adventistas & 2,54 & Neutral \\
\hline
\end{tabular}


De esta tabla, las cinco variables que tuvieron mayor incidencia fueron: vida devocional pobre, falta de visitación pastoral, falta de adaptación al estilo de vida adventista, pecados personales y falta de compañerismo con otros miembros. Ver tabla 10.

TABLA 10

\section{PRINCIPALES RAZONES DE APOSTASÍA SEGÚN APÓSTATAS}

\begin{tabular}{|l|c|l|}
\hline Variable & Resultado & Tendencia \\
\hline Vida devocional pobre & 3,73 & De acuerdo \\
\hline Falta de visitación pastoral & 3,59 & De acuerdo \\
\hline Falta de adaptación al estilo de vida adventista & 3,57 & De acuerdo \\
\hline Pecados personales & 3,57 & De acuerdo \\
\hline Falta de compañerismo con los miembros & 3,54 & De acuerdo \\
\hline
\end{tabular}

\section{Pastores}

En vista de que en la iglesia en estudio cuenta sólo con un pastor, para obtener un consenso pastoral acerca de las razones por las que los miembros abandonan là iglesia, fue necesario encuestar a los pastores que trabajan en la Sección Norte de Chiapas. Estos pastores fueron escogidos debido a que trabajan en la misma región del país. Esta región está poblada por personas que reúnen características similares a la población donde está ubicada la iglesia de Pueblo Nuevo. La información recogida de las encuestas de los pastores revela lo siguiente.

El promedio de edad a la que fueron bautizados fue de 14 años. Un 64 por ciento (16 pastores) fue bautizado entre los 9 y 15 años, mientras que un 32 por ciento (8 personas) lo hizo entre los 16 y 20 años, y un 4 por ciento ( 1 persona) lo hizo después de los 21 . Ver figura 10. Sólo 4 de ellos fueron presionados para ser bautizados y todos 
han tenido cargos en la iglesia.

En los resultados de las variables presentadas se encontró que hay áreas en las que coinciden con los otros grupos encuestados. La tabla 11 muestra todas las respuestas y la 12 señala las que obtuvieron mayor puntaje.

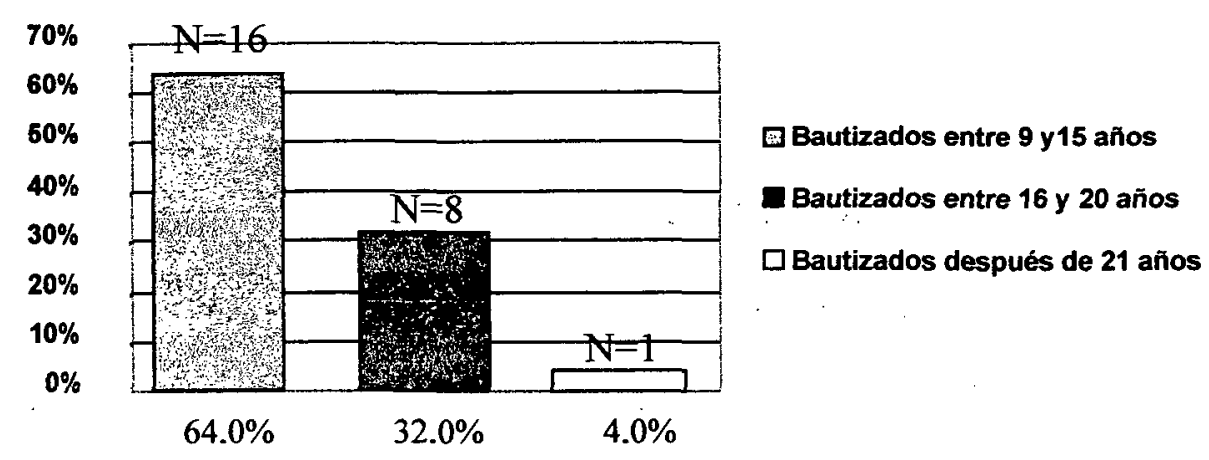

Fig. 10. Comparación de los pastores que fueron bautizados entre los 9 y 15,16 y 20 y después de los 21 años de edad.

TABLA 11

RESULTADO Y TENDENCIA DE LAS VARIABLES QUE SE SUGIRIERON PARA DESCUBRIR RAZONES DE APOSTASÍA ENTRE APÓSTATAS

\begin{tabular}{|l|c|l|}
\hline Variable & Resultado & Tendencia \\
\hline Vida devocional pobre & 3,84 & De acuerdo \\
\hline Conflictos con otros miembros & 3,84 & De acuerdo \\
\hline Falta de visitación pastoral & 3,57 & De acuerdo \\
\hline Hábitos no vencidos & 3,53 & De acuerdo \\
\hline Falta de adaptación al estilo de vida adventista & 3,53 & De acuerdo \\
\hline Falta de participación en actividades misioneras & 3,53 & De acuerdo \\
\hline Cultos que no satisfacen las expectativas & 3,46 & Neutral \\
\hline Pecados personales & 3,46 & Neutral \\
\hline Problemas familiars & 3,50 & Neutral \\
\hline Falta de compañerismo con los miembros & 3,34 & Neutral \\
\hline Injusticias dentro de la iglesia & 3,34 & Neutral \\
\hline Responsabilidades prematuras en la iglesia & 3,34 & Neutral \\
\hline Problemas para guardar el sábado & 3,34 & Neutral \\
\hline Base doctrinal débil & 3,30 & Neutral \\
\hline Presión de familiares no adventistas & 2,84 & Neutral \\
\hline
\end{tabular}


TABLA 12

PRINCIPALES RAZONES DE APOSTASÍA SEGÚN APÓSTATAS

\begin{tabular}{|l|l|l|}
\hline Variable & Resultado & Tendencia \\
\hline Conflictos con otros miembros & 4,84 & Muy de acuerdo \\
\hline Vida devocional pobre & 3,84 & De acuerdo \\
\hline Falta de visitación pastoral & 3,57 & De acuerdo \\
\hline Hábitos no vencidos & 3,53 & De acuerdo \\
\hline Falta de adaptación al estilo de vida adventista & 3,53 & De acuerdo \\
\hline
\end{tabular}

Conclusiones de la aplicación de la encuesta

En resumen, los cuatro grupos encuestados coincidieron con un puntaje mayor en las razones 9 y 10 (por una vida devocional pobre y falta de visitación pastoral), mientras que tres grupos coincidieron con mayor puntaje en las razones 13 y 5 (hábitos no vencidos y conflictos con otros miembros). Otros dos grupos encuestados coincidieron en la razón No. 1 (falta de compañerismo con los miembros). Esto se muestra en la tabla 13.

TABLA 13

RAZONES DE APOSTASÍA QUE TUVIERON MÁS PUNTAJE

\begin{tabular}{|l|c|c|c|c|c|}
\hline Variable & $\begin{array}{c}\text { Gasta } \\
30 \\
\text { años }\end{array}$ & $\begin{array}{c}\text { Mayores } \\
\text { de } 30 \\
\text { años }\end{array}$ & Apóstatas & Pastores & Tendencia \\
\hline Vida devocional pobre & 4,15 & 4,20 & 3,73 & 3,84 & 3,98 \\
\hline Falta de visitación pastoral & 3,81 & 4,16 & 3,59 & 3,57 & 3,78 \\
\hline Hábitos no vencidos & 3,63 & 4,00 & 3,38 & 3,54 & 3,63 \\
\hline Conflictos con otros miembros & 3,63 & 3,80 & 3,62 & 3,85 & 3,72 \\
\hline Falta de compañerismo con los miembros & 3,82 & 3,44 & 3,54 & 3,34 & 3,53 \\
\hline
\end{tabular}


Una tabla comparativa de todos los grupos encuestados, muestra que hubo razones en las que coinciden con mayor puntaje: las primeras cinco son las de mayor incidencia en la mayoria de los grupos. Aún los apóstatas están de acuerdo en que la principal razón por la cual existe apostasía es la falta de devoción personal. Este mismo grupo de apóstatas también señaló que los pecados personales es una de las principales causas por las cuales salieron de la iglesia. Ver tabla 14.

TABLA 14

PRINCIPALES RAZONES DE APOSTASÍA SEGÚN LOS CUATRO GRUPOS ENCUESTADOS

\begin{tabular}{|l|c|c|c|c|c|}
\hline \multicolumn{1}{|c|}{ Variable } & $\begin{array}{c}\text { Hasta 30 } \\
\text { años de edad }\end{array}$ & $\begin{array}{c}\text { Mayores de 30 } \\
\text { años de edad }\end{array}$ & Apóstatas & Pastores & Tendencia \\
\hline Vida devocional pobre & 4,15 & 4,20 & 3,74 & 3,84 & 3,98 \\
\hline Falta de compañerismo & 3,82 & 3,44 & 3,54 & 3,34 & 3,53 \\
\hline Falta de visitación pastoral & 3,81 & 4,12 & 3,60 & 3,57 & 3,77 \\
\hline Hábitos no vencidos & 3,63 & 4,00 & 3,40 & 3,53 & 3,64 \\
\hline Conflictos con miembros & 3,62 & 3,84 & 3,61 & 3,84 & 3,72 \\
\hline $\begin{array}{l}\text { No adaptación al estilo } \\
\text { adventista }\end{array}$ & 3,03 & 3,60 & 3,57 & 3,53 & 3,43 \\
\hline Pecados personales & 3,76 & 3,88 & 3,57 & 3,46 & 3,66 \\
\hline
\end{tabular}

Según la encuesta, entonces, son cinco las razones principales por las cuales los miembros abandonan la iglesia. En orden de incidencia son: (1) vida devocional pobre, (2) falta de visitación pastoral, (3) conflictos con otros miembros, (4) pecados personales y (5) falta de compañerismo con otros miembros. Una sexta razón fue señalada especialmente por el grupo de ex adventistas y pastores: No adaptarse al estilo de vida adventista. 
Teniendo estos resultados como referencia, el siguiente capítulo sugiere un programa de acción a fin de contrarrestar los problemas identificados por los diversos grupos encuestados. 


\section{CAPÍTULO V}

\section{UN PROGRAMA DE RETENCIÓN DE MIEMBROS}

$\mathrm{Al}$ analizar los resultados de las encuestas en relación con las razones de apostasía, es evidente la similitud de opiniones entre la literatura estudiada, cuyo informe presenta el capítulo 2, y las personas encuestadas. Para ver en forma objetiva las razones de apostasía, la tabla 1 muestra esta comparación.

\section{TABLA 1}

\section{COMPARACIÓN DE LAS RAZONDES DE APOSTASÍA EN LA LITERATURA ESTUDIADA Y LAS ENCUESTAS}

\begin{tabular}{|l|l|}
\hline \multicolumn{1}{|c|}{ Informe de la literatura } & \multicolumn{1}{c|}{ Informe de las encuestas } \\
\hline $\begin{array}{l}\text { Falta de atención a las necesidades personales } \\
\text { tanto materiales como espirituales }\end{array}$ & Vida devocional pobre \\
\hline Falta de contextualización del ministerio pastoral & Falta de atención pastoral \\
\hline $\begin{array}{l}\text { Falta de integración en un grupo pequeño donde } \\
\text { encuentren participación más activa y falta de } \\
\text { amigos con quienes relacionarse }\end{array}$ & $\begin{array}{l}\text { Conflictos con otros miembros } \\
\text { Falta de compañerismo con los demás } \\
\text { miembros }\end{array}$ \\
\hline Pecados individuales de los miembros de iglesia & Pecados personales \\
\hline
\end{tabular}

Después de descubrir y comparar las razones principales por las cuales hay apostasía en la iglesia, es necesario buscar soluciones mediante un programa que contribuya a la retención de miembros. Dicho programa involucra al pastor, a los ancianos y a otros dirigentes de la iglesia que tengan la madurez necesaria para colaborar.

En vista de que la falta de devoción personal es la razón principal de apostasía, 
se deberá atender esta área primero. El principio bíblico de Mateo 6:33: "Mas buscad primeramente el reino de Dios y su justicia, y todas estas cosas os serán añadidas", puede aplicarse a las necesidades espirituales de los miembros de iglesia. Con una vida devocional saludable otros problemas pueden resolverse.

La devoción personal debiera iniciar con los líderes de la iglesia. Elena de White dice que "la influencia que ejercemos para bendecir y elevar a los seres humanos se mide por la devoción y la consagración a Cristo que nosotros mismos tenemos". ${ }^{1}$ Agrega que el "estudio diario de las Escrituras tiene una influencia santificadora y elevadora sobre la mente". ${ }^{2}$

Para atender esta necesidad, la iglesia adventista proporciona trimestralmente literatura que ayuda al fortalecimiento de la vida espiritual del individuo. Las lecciones de Escuela Sabática se distribuyen de acuerdo a edades, según el siguiente plan: para los más pequeñitos, de cero a 3 años existe el folleto de cuna; para los niños de 4 a 6 años, el folleto de infantes; para quienes tienen de 7 a 9 años, el folleto de primarios; para los de 10 a 12, el de menores; quienes tienen de 13 a 15 estudian el juvenil; los jóvenes de 16 a 18 años estudian el folleto de jóvenes, y de 19 años en adelante, usan las lecciones de adultos. También existe el libro trimestral llamado El universitario, que en ocasiones se les proporciona a los jóvenes de 16 a 18 años o que estudian grados superiores al bachillerato.

La Iglesia Adventista también publica anualmente libros que contienen lecturas

${ }^{1}$ Elena G. de White, El discurso maestro de Jesucristo (Mountain View, CA: Pacific Press, 1956), 34, 35.

${ }^{2}$ Elena G. de White, Consejos para los maestros (Mountain View, CA: Pacific Press, 1972), 131. 
devocionales diarias basadas en textos bíblicos, comúnmente llamados "matinales". Por otro lado, se promueve el plan de lectura de la Biblia denominado "año bíblico" y la lectura de libros de Elena G. de White combinados con la lectura de la Biblia.

Aunque lo anterior tiene mucho valor, las encuestas revelan que, el problema principal por el cual existe apostasía es la falta de devoción personal.

Elena G. de White recomienda a cada miembro de iglesia adoptar algún sistema de estudio personal.

Así como el minero cava en la tierra en busca del áureo tesoro, también nosotros debiéramos buscar ferviente y persistentemente el tesoro de la Palabra de Dios. En el estudio diario, el método de seguir versículo por versículo es a menudo muy útil. Tome el estudiante un versículo y concentre su mente en averiguar el pensamiento que Dios quiere comunicarle, y luego espáciese en él hasta asimilarlo. Un pasaje así estudiado hasta que su significación se haga clara, es de más valor que la lectura de muchos capítulos sin un propósito definido, y sin que se adquiera instrucción positiva de ellos. ${ }^{1}$

Otros beneficios del estudio personal diario son el fortalecimiento del intelecto y el conocimiento de las grandes obras de Dios en la naturaleza, el conocimiento correcto de cómo vivir a fin de disfrutar de mayor felicidad, la fortaleza para soportar las tentaciones de Satanás, el entrenamiento para toda buena obra y preparación para testificar. ${ }^{2}$

La misma Biblia invita a su estudio constante. Jesús dijo: “en ellas tenéis la vida eterna" (Jn. 5:39). Un ejemplo bíblico de estudio diligente es el de los bereanos, que fueron más nobles que los de Tesalónica porque examinaban cada día las Escrituras (Hch. 17:11). Pablo le reconoce a Timoteo el hecho de que desde la niñez conocía las Escrituras (2 Ti. 3:15).
'Ibid., 445.
${ }^{2}$ White, Joyas de los testimonios, 1:357. 
A continuación se presenta un programa para fortalecer la vida devocional de los miembros.

\section{Programa para fortalecer la vida devocional}

Propósito y objetivos del programa

En vista del gran número de apostasías que existe en la Iglesia Adventista, este programa tiene como propósito entrenar a un grupo de doce miembros de la iglesia de Pueblo Nuevo para que enseñen a otros a tener una vida devocional saludable para afirmar su fe.

Los objetivos son tres: (1), que el 80 por ciento de los hogares adventistas de la Iglesia Central de Pueblo Nuevo celebren el culto familiar; (2), que los miembros que tienen de cero a dos años de bautizados sean asimilados mediante grupos pequeños 0 mediante el trabajo de miembros de más experiencia; (3), aumentar el nivel de retención de miembros al 80 por ciento de los que ingresan cada año a la iglesia. El programa se inicia con la instrucción a los líderes laicos de la iglesia.

\section{Instrucción de líderes laicos}

En vista de que los líderes son el ejemplo de la congregación, son ellos los primeros en procurar tener una vida devocional saludable. Para que esto ocurra, el pastor tiene que motivarlos e instruirlos mediante un programa especial para ellos, para que posteriormente, ellos enseñen a los demás miembros de la iglesia. El procedimiento para instruirlos se sugiere que sea de la siguiente manera:

El pastor selecciona a doce líderes a quienes instruye durante cuatro semanas (de domingo a jueves). Entre los líderes seleccionados también debe haber mujeres, pues hay hermanas que podrían ser mejor atendidas por una mujer debido a las situaciones propias 
de las mujeres. Las primeras tres semanas son para recibir clases de parte del pastor. La cuarta semana es para organizar el trabajo con los miembros. Después de ser instruidos y definir cómo van a trabajar, se asigna un grupo de miembros o de familias a cada apóstol para que se les enseñe cómo llevar una vida devocional saludable.

El grupo de líderes seleccionado por el pastor recibe el nombre de "los doce apóstoles", porque serán los enviados a los miembros para confirmarlos en la fe. La instrucción consiste en el desarrollo de tres temas: hábitos devocionales, cómo dirigir un grupo pequeño y cómo realizar el culto familiar (los bosquejos para todos los temas aparecen en el apéndice B). Una vez que el pastor escogió a sus líderes, debieran ponerse de acuerdo en cuanto al lugar, horario y la programación para cada día. A continuación se presenta una sugerencia.

\section{Lugar}

Las reuniones pueden ser en la casa del pastor o en un anexo de la iglesia. Si la casa del pastor tiene espacio suficiente es recomendable que sea allí, debido a que el ambiente es más familiar y a la vez es informal.

\section{Primera semana}

El primer tema, "hábitos devocionales" tendrá una semana de duración y con un horario sugerente de 7:00 a 8:00 P. M.

El programa sugerente para el primer día es:

1. Bienvenida por el pastor de la iglesia (2 minutos).

2. Oración para iniciar la sesión (1 minuto).

3. Presentación de cada uno de los apóstoles (10 minutos). En esta 
presentación, cada uno de los apóstoles puede decir su nombre, el nombre de su esposa y cuántos hijos tiene. Si no es casado, entonces puede decir el nombre de sus padres y cuántos hermanos tiene.

4. Presentación de los propósitos y objetivos del programa para evitar apostasía (5 minutos).

5. Discusión sobre los propósitos y objetivos del programa. Esta discusión será en grupos de tres o cuatro personas (10 minutos)

6. Presentación del programa general (20 minutos)

7. Retroalimentación (5 minutos)

8. Clausura ( 3 minutos)

9. Canto (3 minutos)

10. Oración final (1 minuto)

El programa para los otros cuatro días de la semana podría ser de la misma manera, con la variante de que en lugar de los veinte minutos para presentar el programa (punto número 6), se exponga el tema sobre hábitos devocionales. Las clases específicas para cada día serán:

1. Cómo estudiar la Biblia con provecho

2. Cómo utilizar otras herramientas para comprender la Biblia

3. El lugar que ocupan los escritos de Elena G. de White en la Iglesia Adventista

4. Métodos de estudio para los niños

\section{Segunda semana}

En la segunda semana se puede seguir el mismo orden del programa o variar de 
acuerdo a los gustos de los doce apóstoles. No se debiera ser exigente ni inflexible en el orden del programa, pero debe tenerse cuidado de no relajar demasiado la reunión de manera que se le reste importancia.

El tema para desarrollar durante la segunda semana es "cómo dirigir un grupo pequeño". Para cada día de la semana se abordarán las siguientes clases específicas:

1. Base bíblica y de Elena G. de White para los grupos pequeños

2. La importancia y ventajas de los grupos pequeños

3. Modalidades de los grupos pequeños

4. Actividades que se pueden realizar en un grupo pequeño

5. Cómo se multiplican los grupos pequeños

\section{Tercera semana}

Para la tercera semana el tema de discusión será "cómo realizar el culto familiar". Las clases específicas para cada día se presentan a continuación:

1. La importancia de la familia en la Biblia y los escritos de Elena G. de White

2. Problemas más comunes que amenazan la estabilidad de la familia

3. La participación de los niños en el culto familiar

4. 101 maneras de celebrar el culto familiar

5. Ventajas de una familia cristiana unida y feliz

$\mathrm{Al}$ final de la tercera semana se debiera hacer una evaluación del programa mediante el formulario sugerente en el apéndice C.

\section{Cuarta semana}

Una vez que ha terminado la instrucción, los apóstoles deben ser informados 
sobre la forma de trabajar con los miembros de iglesia. El pastor debiera tener disponible la siguiente información:

1. Cuántos miembros de iglesia existen en total

2. Cuántos miembros tienen de cero a dos años de bautizados

3. Cuántos miembros asisten solos a la iglesia cuyas familias no son adventistas todavía

4. Cuántas familias adventistas existen por barrio

5. En qué lugares se pueden reunir

El pastor reparte tres familias a cada apóstol para que empiece a trabajar con ellas a partir de la siguiente semana de que terminó la instrucción. De esta manera se estarán atendiendo 36 familias a la vez.

A las mujeres que fueron capacitadas se les distribuye damas de la iglesia que asisten solas a la iglesia y cuyas familias no son adventistas todavía. En este caso, la "apóstol" debiera hacer provisión para el lugar donde se reunirá con ellas.

El propósito de la atención a las familias es enseñarles cómo tener una vida devocional saludable utilizando los recursos del culto familiar y los momentos de estudio personal.

A continuación se presenta el programa para las familias de la iglesia.

Instrucción para familias

Los “apóstoles", debidamente instruidos, están preparados para atender a las familias de la iglesia. La atención consiste en celebrar el culto familiar durante una semana con cada familia hasta completar tres familias (para las ideas para el culto 
familiar ver el apéndice D). También consiste en enseñarles cómo tener momentos de estudio personal durante el día.

Los elementos que el culto familiar debiera tener son: adoración, oración, agradecimiento, testimonio, reflexión y petición. Se debiera tener cuidado de no ser rígido en el programa del culto familiar. Es mejor que, aunque haya un programa elaborado previamente, haya espontaneidad para que puedan participar todos los miembros de la familia. A continuación se presenta una idea para el programa.

1. Cantos (dos cantos infantiles y dos juveniles) (10 minutos)

2. Oración (una vez puede ser hecha por uno de los padres, otra vez por uno de los hijos pequeños y luego por uno de los hijos mayores) (1 minuto)

3. Sesión de agradecimientos (cada miembro de la familia expresa uno) (3 minutos)

4. Testimonios (3 minutos)

5. Reflexión (cada día puede haber una reflexión tomada de las ideas del apéndice D) (5 minutos)

6. Petición (una por cada miembro de la familia) (3 minutos)

7. Al final, uno de los miembros de la familia hace la oración

El horario debe ser acordado entre el apóstol y la familia con la cual realizará el culto familiar durante la semana. Debiera cuidarse de no extenderse más de 30 minutos.

Después de una semana realizando el culto familiar con una familia, el apóstol va por otra semana con otra familia hasta completar las tres. Al mismo tiempo le da seguimiento a la familia anterior mediante una visita semanal en la cual el apóstol afirma lo que se ha realizado ya. 
Se puede emplear un formulario para evaluar este trabajo. Un ejemplo de este formulario aparece en el apéndice $E$.

\section{Visitación pastoral}

La visitación pastoral de casa en casa es uno de los medios eficaces de atender las necesidades espirituales de los miembros y retenerlos en la iglesia. Comentando Hch. 20:20, el Comentario biblico adventista asegura que "ningún ministro puede cuidar adecuadamente de su grey sin esta visitación de casa en casa".

Hezequiah Harvey cita a Juan Hall: "Debemos asegurarnos que nada nos impide para la visitación pastoral. Es de suma importancia que el pastor llegue a conocer la gente en sus hogares, y que la gente lo conozca a él. Los niños y jóvenes deben conocerle. Los hombres deben conocerle. Únicamente así se pueden entender las necesidades básicas de la gente y adaptar su predicación a ellas" Señala también que el Dr. Cuyler, pastor en Brooklyn, dice: "vaya durante la semana a los que quiere que vengan a usted en el día del Señor". 2

Raymond Calkins le da especial importancia a la visitación pastoral y, en su libro El romance del ministerio, recomienda la planificación de esas visitas, no "en forma mecánica, sino en forma humana". Los casos que requieren prioridad son los enfermos, los atribulados y los débiles en la fe. ${ }^{3}$

\footnotetext{
l'De casa en casa" [Hch. 20:20], CBA, 6:385.

${ }^{2}$ Hezequiah Harvey, "La visitación pastoral” http://amen.net/lb/articulos/pastor4.htm
} (14 de julio de 2002). 153.

${ }^{3}$ Raymond Calkins, El romance del ministerio (Boston: Pilgrim, 1943), $152 .$, 
En la agenda del pastor no debe faltar el programa de visitación. A continuación se presenta un programa de visitación semanal para el pastor.

$$
\text { Programa semanal para el pastor }
$$

Domingo. Atención a los clubes del ministerio juvenil y dirección de juntas y concilios.

Lunes. Día libre para atender a la familia.

Martes. Atención a asuntos administrativos tales como secretaría, tesorería, etc.;

Miércoles. Visitación pastoral y predicación en la iglesia más próxima a la zona geográfica visitada.

Jueves. Visitación pastoral.

Viernes. Estudio personal, preparación de sermones, clases etc. Puede predicar en alguna iglesia o recibir el sábado con alguna de las familias de la iglesia.

\section{Programa diario para el pastor}

El pastor debe saber qué hará cada día de la semana. Para facilitar la fluidez de sus actividades el siguiente programa diario le será útil.

$\begin{aligned} 6: 00 & \text { Levantarse } \\ 6: 00-6: 30 & \text { Aseo personal } \\ 6: 30-7: 00 & \text { Devoción personal } \\ 7: 00-7: 30 & \text { Culto familiar } \\ 7: 30-8: 00 & \text { Desayuno } \\ \text { 8:00-13:00 } & \text { Visitación } \\ 13: 00-14: 00 & \text { Comida }\end{aligned}$


14:00-14:40 Receso

14:40 - 15:00 Preparación para continuar sus actividades

15:00-19:00 Visitación

19:00 - 19:30 Regreso a casa

19:30 - 20:00 Culto familiar

Una agenda sugerente para la visitación está en el apéndice F. En esta agenda se incluye la visitación pastoral a todo el distrito de Pueblo Nuevo 1, debido a que el pastor es responsable de la atención a todas sus iglesias. El hecho de tener un programa de visitación, no significa que deba ser inflexible en seguirlo. Puede haber emergencias, por ejemplo, un enfermo o un funeral.

El trabajo de visitación pastoral debe ser evaluado. Esta evaluación le ayudará al pastor a conocer su avance en su trabajo. Una sugerencia para la evaluación de la visitación pastoral aparece en el apéndice G.

La visitación pastoral no se llama así porque sea un pastor quien la realiza, sino por el carácter pastoral que tiene. Por esta razón, el pastor también debe capacitar a líderes laicos para que la puedan realizar. Una iglesia con líderes capacitados para atender pastoralmente a los miembros no tiene sólo un pastor. Tiene muchos pastores que contribuirán al crecimiento y fortalecimiento espiritual de los miembros evitando así la apostasía.

\section{Otras actividades que ayudan a la retención}

Resolución de conflictos entre miembros

Siempre han existido conflictos dentro de la iglesia. Durante el periodo de la iglesia primitiva el apóstol Pablo tuvo que enfrentar algunos conflictos muy dificiles. En 
Corinto llegaron el extremo de discutir los problemas aún delante de los tribunales (1 Co. 6:1-8). Ante esta situación, Pablo "deseaba que comprendieran que no estaban dando un ejemplo de vida cristiana victoriosa ante los paganos. Los miembros de la iglesia deben mantener en sujeción sus sentimientos y deseos personales dando prioridad a las cosas que conciernen al bienestar de la iglesia. No debe permitirse que las diferencias entre los hermanos ensombrezcan el buen nombre de la iglesia". ${ }^{1}$

Según Santiago, "el egoísmo que constantemente busca reconocimiento y ventajas, es la raíz de todos los conflictos personales que con frecuencia producen rivalidades". ${ }^{2}$ Estos pleitos, escribe Elena de White, "son un oprobio para la causa de la verdad. Los cristianos que recurren a la ley unos contra otros exponen a la iglesia al ridículo de sus enemigos, y provocan el triunfo de las potestades de las tinieblas. Hieren de nuevo a Cristo, y le exponen al vituperio. Al pasar por alto la autoridad de la iglesia, manifiestan menosprecio por Dios, quien dio autoridad a la iglesia".3

La forma como la iglesia primitiva abordó estos problemas y el consejo para la iglesia actual sirven como guía para procurar soluciones pacíficas. Al respecto Elena de White dice que "cuando se suscitaban disensiones en alguna iglesia local. ... no se consentía en que la cuestión dividiese a la iglesia, sino que se la sometía a un concilio general de todos los fieles, constituido por delegados de las diversas iglesias locales con los apóstoles y ancianos en funciones de gran responsabilidad". ${ }^{4} \mathrm{Y}$ aconseja: "Miremos

\footnotetext{
1“"Para avergonzaros", [1 Co 6:5], $C B A, 6: 393$.

${ }^{2 "}$ "En vuestros miembros", [Sgo 4:1], $C B A, 7: 547$.

${ }^{3}$ White, Los hechos de los apóstoles, 247.

${ }^{4}$ Ibid., 79.
} 
la cruz del Calvario. Es la garantía de amor ilimitado, de la inconmensurable misericordia del Padre celestial. ¡Oh, si todos se arrepintieran e hicieran sus primeras obras! Cuando los miembros de las iglesias lo hagan, amarán a Dios sobre todas las cosas y a su prójimo como a sí mismos". ${ }^{1}$

Por lo anterior, las siguientes estrategias pueden ayudar a los recién ingresados.

\section{Semana de la amistad}

Se puede promover una semana de la amistad cada cuatro meses donde se destaquen valores cristianos tales como paciencia, tolerancia, amor, comprensión, abnegación, servicio desinteresado, dadivosidad y la buena voluntad.

Algunos pasajes bíblicos que ayudan para estos efectos pueden ser: la relación entre Abraham y Lot (Gn. 13 y 14); el encuentro de José y sus hermanos (Gn. 42, 43 y 45); los hermanos Moisés, María y Aarón (Ex. 2, 6 y 15); la relación entre Josué y Moisés (Jos. 1); la historia de Ruth y Noemí (Rt. 1 al 4); la amistad de David y Jonatán (1 S. 18 y 20); la bondad de David hacia Mefi-boset (2 S. 9) y la preeminencia del amor (1 Co. 13).

Se pueden extraer lecciones de amistad de varias historias bíblicas. El tema y su presentación puede ser preparado por familias, donde los padres y los hijos estén involucrados. La enseñanza queda mejor ilustrada si la presentación es acompañada por un cuadro plástico o un diálogo.

\footnotetext{
${ }^{1}$ White, Cada día con Dios, 88.
} 


\section{Actividad para un viernes de cada mes}

Se puede dedicar un viernes de cada mes para tener reuniones por barrios. Las familias que viven en una zona determinada se reunirán para tener la recepción de sábado juntas. Un líder previamente nombrado por el conjunto de familias o uno de los apóstoles, se encargará de buscar expositores de temas cuyo título general podría ser "Miremos a la cruz". En estos temas se exalta la cruz de Cristo como el único medio que ayuda a la unidad y derriba las barreras y diferencias entre hermanos. Después de la parte espiritual de la reunión, la familia anfitriona ofrece un pequeño aperitivo con el cual se clausura el programa.

\section{Intercambio de programas}

Existen iglesias que alimentan enemistades entre sí. Cuando éstas están en una misma comunidad, el daño que se hacen mutuamente perjudica la imagen que debiera proyectarse hacia los no adventistas. Cuando esto ocurre, se pueden aliviar las tensiones por medio de intercambio de programas.

El pastor del distrito, el anciano encargado o el director de jóvenes o de escuela sabática llegan a un acuerdo con sus homólogos de la otra iglesia para intercambiar un programa, ya sea de jóvenes, de escuela sabática o un programa social. Las ventajas de esta actividad son que involucran a mayor número de personas en su presentación y la iglesia se esmera por realizar un programa de calidad. Los muchachos conocen a otros jóvenes y señoritas de otras iglesias y se aprovecha el evento para invitar a amigos y familiares no adventistas. Los recién ingresados encuentran así otra forma mediante la cual serán asimilados. 
Sin embargo, en caso de que el conflicto sea mayor y no se encuentre solución, la intervención de un grupo de ancianos bajo la dirección del pastor puede ser una estrategia. Si tuviera que ser así, el pastor debiera realizar un trabajo personal previo con los miembros en conflicto. No hay que olvidar que una labor pastoral efectiva aliviará los problemas de la iglesia como institución y como individuos.

\section{Compañerismo con los miembros}

El compañerismo puede evitar pecados de los miembros de iglesia. El hombre fue creado como un ser sociable. La declaración, "no es bueno que el hombre esté sólo" (Gn. 2:18), no se refiere únicamente a la necesidad de tener una esposa. También enseña que Dios "nos creó para el compañerismo, ya sea mediante la relación matrimonial, de la familia, de amistades o de todas ellas a la vez". ${ }^{1}$

Los recién ingresados a la iglesia adventista esperan encontrar ese compañerismo con los demás miembros. $\mathrm{Y}$ aunque la iglesia cumple su ministerio en la proclamación de la Palabra y en el servicio cristiano, Werner Vyhmeister declara que "muy poca atención dan al tercer pilar de un ministerio verdaderamente bíblico y completo, el del compañerismo".2

"Encuestas hechas en la Iglesia Adventista de Norteamérica indican que el 70\% de los que dejaron la iglesia podrían haber continuado si hubiesen tenido un sólido compañerismo de los hermanos". 3

\footnotetext{
"Nuestra naturaleza social", <http://www.tagnet.org/ficoa/advent/esabatica/ e1999203.html\#domingo $>$ (13 de junio de 2002).

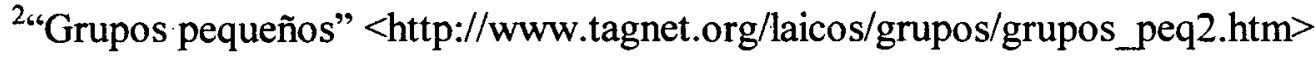
(13 de junio de 2002).

${ }^{3}$ Ibíd.
} 
El problema de la apostasía no es tanto doctrinal como social. Esto está demostrado en un estudio realizado por la División Sudamericana, el cual informa que "sólo el 2\% de las personas que dejaron la iglesia, dejan de creer en las enseñanzas bíblicas. El $98 \%$ restante dejó porque tuvo problemas de relaciones humanas". 1

Elena de White también reconoce que existe pérdida de miembros de iglesia debido a la falta de compañerismo. Dice: "En nuestra asociación como cristianos perdemos muchos por falta de simpatías mutuas. El que se encierra en sí mismo no cumple la misión que Dios le ha designado. El ejercicio apropiado de los elementos sociales de nuestra naturaleza nos ayuda a simpatizar con otros y es un medio de desarrollarnos y fortalecernos en el servicio de Dios".

En relación con la responsabilidad de los miembros de experiencia, la misma autora dice que "los que se encierran en sí mismos y no están dispuestos a prestarse para beneficiar a otros mediante amigable compañerismo, pierden muchas bendiciones; porque merced al trato mutuo el entendimiento se pule y refina; por el trato social se formalizan relaciones y amistades que acaban en una unidad de corazón y en una atmósfera de amor agradables a la vista del cielo". ${ }^{3}$

\section{Actividad sugerente para fomentar el compañerismo}

El pastor elige diez familias de las que han crecido espiritualmente. Les asigna

${ }^{1}$ Seminarios de la División Sudamericana, "Prevención apostasía", disco 1:14

${ }^{2}$ Elena G. de White, El camino a Cristo (Mountain View, CA: Pacific Press, 1979), 73.

${ }^{3}$ Elena G. de White, Mensajes para los jóvenes (Mountain View, CA: Pacific Press, 1967), 403. 
trabajo para atender a los recién bautizados en el área social y afectiva. Proveerán toda posibilidad de conocer y tratar con la mayor cantidad posible de miembros de la iglesia. El trabajo consiste en invitar a comer cada sábado a una persona o familia recién bautizada, convivir con ellos en todo momento durante el sábado. Estarán juntos en la comida, al dar un paseo por el parque o el bosque, al hacer visitas misioneras, visitar a enfermos, o dar algún estudio bíblico. Asistirán juntos al programa de jóvenes de la iglesia. También en la reunión social estarán juntos para jugar.

El próximo sábado, harán exactamente lo mismo con otra familia de la iglesia, y así sucesivamente, cada sábado, hasta completar diez, en diez lugares diferentes conociendo a diez familias y a los amigos de las diez familias.

Es importante que cuando se invite a comer a las personas nuevas en la fe, no se hagan comidas especiales, ni cantidades excepcionales. Lo que vale es estar juntos y participar con sencillez de la camaradería.

La iglesia organizará una comisión sencilla, que se encargue de coordinar este trabajo. Es tan importante como dar estudios bíblicos, ya que si se bautizan y después se desaniman, no se avanza en la retención de miembros. ${ }^{1}$

\section{Participación de los grupos pequeños}

Según Johnson, "un grupo pequeño es una reunión deliberada y frente a frente de 3 a 12 personas que se reúnen en un horario regular, con el propósito común de

\footnotetext{
${ }^{1}$ Seminarios de la División Sudamericana, disco 1:14.
} 
desarrollar relaciones, satisfacer las necesidades que sienten los miembros del grupo, crecer espiritualmente, y trazar planes para llevar a otros a aceptar a Jesús como Señor y Salvador de sus vidas".

Por su parte, Christian A. Schwartz dice que la característica básica de los grupos pequeños es la integralidad; es decir, "no sólo se hable de textos bíblicos, sino que se relacionen las verdades bíblicas con la vida diaria de sus integrantes".?

El grupo pequeño puede estar formado por zona geográfica o por afinidad. Sin embargo, da más resultados por afinidad, debido a que los integrantes se identifican entre sí con mayor facilidad. A continuación se presenta un programa sugerente para la primera reunión de un grupo pequeño.

1. Bienvenida por el líder.

2. Presentación de los miembros. En esta presentación se puede dar algo de información del integrante: su nombre, su edad, y sus actividades preferidas (ejemplo: me llamo Juan Pérez, tengo 19 años y me gusta pescar).

3. Juego: Aprendiéndose el nombre de todos. Esta actividad se realiza en círculo: cada uno de los integrantes escoge una cualidad personal que inicie con la primera letra de su nombre, luego el segundo del círculo repite el nombre y la cualidad del vecino y dice lo suyo propio (ejemplo: me llamo Juan y soy “jovial”; el siguiente dice: él se llama Juan y es jovial, yo me llamo Pedro y soy "paciente". A partir de ese momento cada uno se refiere al otro por su cualidad.)

'Johnson, 99.

${ }^{2}$ Christian A. Schwarz, Desarrollo natural de la iglesia: Ocho caracteristicas básicas de una iglesia saludable (Barcelona: CLIE, 1996), 32. 
4. Confraternización (en grupos de tres personas para hablar sobre una experiencia personal que haya impactado su vida)

5. Momentos de reflexión personal (se escoge un versículo para que mediten por cinco minutos sobre él y después cada uno dice el mensaje que encontró)

6. Cantos (unos tres cantos juveniles)

7. Convivio (un chocolate con galletas)

8. Anuncio de la próxima reunión (lugar y hora).

9. Despedida (con una oración por el líder)

El programa de las siguientes reuniones puede variar según el acuerdo que el grupo tome.

Según Duane L. Anderson cada persona que ingresa a la iglesia debe crecer en un grupo pequeño hasta llegar a un estado de madurez espiritual de manera que esté capacitado para enseñar a otros. Para madurar es necesario que el recién ingresado pase por un proceso. Este proceso empieza con lo que él llama bebé espiritual. Es un recién nacido que necesita ser guiado en el estudio de las Escrituras (2 Ti. 3:15; 2 P. 2:2) para que pueda escalar las siguientes etapas que son: párvulo espiritual, muchacho espiritual, joven espiritual, padre espiritual, padre espiritual con Timoteos, padre espiritual con Timoteos que enseñan a hombres fieles y padre espiritual con Timoteos quienes equipan a hombres fieles para enseñar a otros. ${ }^{1}$ Ver en los apéndices $\mathrm{H}$ e I la tabla de crecimiento espiritual de Anderson y las preguntas que puede hacerse para ayudar al recién ingresado a pasar por los diferentes niveles de crecimiento espiritual.

${ }^{1}$ Duane L. Anderson, Manual de entrenamiento para lideres de grupos pequeños (Norwalk, CA.: American Indian Bible Institute, 1996), 15. 


\section{Adaptación al estilo de vida adventista}

El recién ingresado a la iglesia es como un bebé que debe aprender a hacerle frente a la vida. Para un bebé, sus padres son los primeros en enseñarle a dar los primeros pasos que constituyen la base para que pueda valerse por sí solo. Lo mismo ocurre con un bebé espiritual. Hay qué enseñarle a vivir como adventista.

El estilo de vida adventista es muy vasto. Incluye la comida, el vestido, las diversiones, el trabajo, el descanso, la forma de noviar y la educación de los hijos. El proceso para que un recién ingresado adopte éste estilo de vida es aproximadamente de dos años. Para lograrlo se necesita el trabajo misionero de hermanos con mucho amor, tacto y paciencia. ${ }^{1}$

A menudo sólo se critica a los miembros que no se adaptan rápido al estilo de vida adventista, llegando a la exageración en cuanto a comida o vestido o algún otro elemento. Pero la iglesia tiene la responsabilidad de inducirlos mediante cursos que pueden ser presentados por la Sociedad de Dorcas u otro departamento de la iglesia.

Se debieran programar cursos de costura para atender las necesidades del hogar, de alta costura para que las personas puedan ganarse la vida, de cocina lacto ovo vegetariano para el hogar, de cocina profesional para tener su propio empleo, de higiene y cuidado del niño para madres, de prevención de adicción a productos químicos, de desintoxicación tabáquica o alcohólica y otros cursos que promuevan un mejor estilo de vida. $^{2}$

\footnotetext{
${ }^{1}$ Seminarios de la División Sudamericana, disco 1:14. ${ }^{2}$ Ibíd.
} 


\section{CAPÍTULO VI}

\section{RESUMEN, CONCLUSIONES Y RECOMENDACIONES}

Después de haber analizado y evaluado las actividades de la Iglesia Adventista de Pueblo Nuevo Solistahuacán, Chiapas, éste capítulo presenta conclusiones organizadas de la siguiente manera: primero, un resumen del trabajo realizado. Después se presentan las conclusiones que son el resultado de la investigación y finalmente recomendaciones para que el programa de retención tenga resultados en cạda iglesia en la cual se implemente.

\section{Resumen}

La evangelización no consiste sólo en bautizar gente y convertirla en miembros de iglesia. La meta de la Gran Comisión no es bautizar sino discipular. Es convertir en discípulo a cada persona que ingresa a la iglesia.

Hasta este momento la iglesia se ha preocupado por alcanzar blancos de bautismos, pero no se ha preocupado por alcanzar blancos de discípulos. En la práctica los pastores y líderes trabajan bajo presión por lograr blancos de almas. La misma iglesia, como organización, no parece dar suficiente importancia a la retención de miembros. El resultado evidente es un alto índice de apostasía. El crecimiento de la iglesia no es real, pues la cantidad de bautismos no corresponde a la cantidad de nuevas iglesias plantadas, ni a la división de distritos. 
El Nuevo Testamento insiste en que no sólo se debe bautizar sino discipular. Para discipular se debe confirmar a los recién ingresados. El Nuevo Testamento también emplea diferentes términos griegos para referirse al trabajo de retención de miembros que líderes de la iglesia deben realizar. Entre estos términos el más importante es menō (permanecer).

En la parábola de la vid (Jn. 15) Jesús enfatiza el hecho de permanecer en él. El verbo griego menō es utilizado once veces en sus diferentes inflexiones para insistir en la importancia de permanecer. Sin embargo aún en la iglesia primitiva existía apostasía. Lo mismo ocurre actualmente en las distintas denominaciones, incluyendo la Iglesia Adventista del Séptimo Día.

La literatura sobre iglecrecimiento y Elena G. de White están de acuerdo en que un método de retención es enseñar a los miembros a trabajar en favor de otros. También lo es el estudio personal fortalecido con buenos cultos y programas en la iglesia. Pero uno de los mejores métodos es la inclusión en un grupo pequeño a cada uno de los recién ingresados.

Según el estudio realizado entre miembros de iglesia, apóstatas y pastores existen cinco razones por las cuales hay apostasía. Estas cinco razones son: (1) vida devocional pobre, (2) falta de visitación pastoral, (3) conflictos con otros miembros, (4) pecados personales y (5) falta de compañerismo con otros miembros.

Para contribuir a la retención el capítulo 5 provee programas que, adaptados a cada iglesia y distrito, darán buenos resultados. En estos programas el pastor desempeña un rol importante, el rol de instructor de líderes laicos. Estos líderes laicos ayudarán en la atención a las familias de la iglesia realizando una obra pastoral de gran valor. De esta 
manera el pastor se multiplica y la iglesia tendrá varios pastores para ser atendida en vez de uno solo.

\section{Conclusiones}

Tomando en cuenta que la meta final de la Gran Comisión es convertir a los bautizados en discípulos afirmados, y en vista de que en la iglesia existen índices muy altos de apostasía, se concluye que:

1. Deben trazarse planes y programas variados de retención de miembros en cada una de las iglesias adventistas.

2. En todos los programas de retención deben estar involucrados el pastor y los líderes voluntarios de la iglesia.

3. Una vez que se planifique alguna actividad de retención debe realizarse celosamente y con entusiasmo. Es mucho más dificil que un apóstata regrese a la iglesia que ganar a un nuevo miembro, por lo tanto es deber de todos cuidar a los que están adentro.

4. Un programa de retención de miembros no funciona exactamente igual y con los mismos resultados en todas las iglesias. Deben tomarse en cuenta las características demográficas, geográficas y socioculturales de la iglesia para diseñar un programa adecuado.

\section{Recomendaciones}

Aunque la investigación y el estudio fueron realizados en la iglesia de Pueblo Nuevo, los resultados coinciden con lo que otras iglesias parecen necesitar. Por lo tanto, las siguientes recomendaciones pueden ser útiles. 
1. Que cada pastor, al llegar a una nueva iglesia o distrito, realice un estudio sobre las razones de apostasía para diseñar un programa adecuado de retención de miembros.

2. Que el pastor distrital tenga la mentalidad de un pastorado largo, por lo menos de nueve años, y que haga planes de trabajo a largo plazo en los cuales se incluya un programa permanente de retención.

3. Que las administraciones de los diferentes niveles de la Iglesia Adventista pongan mayor atención a los problemas de apostasía y tengan seminarios para los pastores distritales cobre cómo retener a los miembros de la iglesia.

4. Que las asociaciones realicen menos cambios de pastores para que éstos puedan implementar programas de retención que se puedan evaluar y contextualizar. 


\title{
APÉNDICE A
}

\section{Iglesia Adventista del Séptimo Día, A. R.}

\author{
Encuesta
}

La presente encuesta tiene el propósito de descubrir las razones más comunes por las que los miembros abandonan la iglesia. Sea tan amable de contestar todas las preguntas según su criterio. La información que usted brinde será totalmente confidencial.

A. Información personal:

1. ¿A qué edad fue bautizado?

2. ¿Fue presionado por algún laico o pastor para ser bautizado? Sí No

3. ¿Ha tenido cargos en la iglesia? Sí

No

4. ¿Asiste regularmente a los cultos?

Sí

No

5. ¿Participa activamente en los programas de la iglesia?

6. ¿Cuánto tiempo hace que no asiste a la iglesia? años, meses.

B. Coloque una $\underline{\mathbf{X}}$ en la línea en blanco según se aplique a usted:

Pastor

Menor (hasta 15 años)

Ex adventista Joven (de 16 a 30 años)

C. Conteste la pregunta ¿por qué los miembros abandonan la iglesia? Encerrando en un círculo el número de acuerdo a su criterio, según el parámetro siguiente: $5=$ Muy de acuerdo, $4=$ De acuerdo, $3=$ Neutral, $2=$ En desacuerdo $1=$ Muy en desacuerdo

1. Falta de compañerismo con los miembros

$\begin{array}{lllll}5 & 4 & 3 & 2 & 1\end{array}$

2. Cultos que no satisfacen las expectativas
5
4
3
2
1

3. Presión de familiares no adventistas

5

4

3

2

1

4. Problemas para guardar el sábado 5

4

3

2

1 
5. Conflictos con otros miembros
5
4
3
2
1

6. Base doctrinal débil 5 3

2

1

7. Falta de participación en actividades misioneras 5 4 3 2

8. Injusticias dentro de la iglesia 5 $4 \quad 3$ $2 \quad 1$

9. Vida devocional pobre

$\begin{array}{lllll}5 & 4 & 3 & 2 & 1\end{array}$

10. Falta de visitación pastoral $\begin{array}{lllll}5 & 4 & 3 & 2 & 1\end{array}$

11. Pecados personales

$\begin{array}{llllll}5 & 4 & 3 & 2 & 1\end{array}$

12. Problemas familiares (con la esposa, el esposo o los hijos) $\begin{array}{lllll}5 & 4 & 3 & 2 & 1\end{array}$

13. Por hábitos no vencidos $\begin{array}{llllll}5 & 4 & \cdot 3 & 2 & 1\end{array}$

14. Por no adaptarse al estilo de vida adventista 5 4 3

15. Por darles responsabilidades prematuramente 5 4 3 2 


\section{APÉNDICE B \\ BOSQUEJOS PARA LAS CLASES}

1. Bosquejo para la clase

"Cómo estudiar la Biblia con provecho"

\section{INTRODUCCIÓN}
A. La Biblia como la Palabra de Dios
B. Importancia del Estudio de la Biblia
C. Mensaje cristocéntrico de la Biblia

\section{DESARROLLO}

A. Métodos de estudio de la Biblia

1. Método devocional

2. Método inductivo

3. Método deductivo

B. Contenidos básicos de la Biblia

1. Historia

2. Profecía

3. Poesía

C. Beneficios del estudio de la Biblia

1. Conocimiento de Dios

2. Paz espiritual y mental

3. Seguridad ante las crisis

4. Esperanza

\section{CONCLUSIÓN}

A. La Biblia, como la Palabra de Dios, debe ocupar un lugar especial en nuestras vidas

B. El estudio mediante un método específico trae mayores beneficios. 
2. Bosquejo para la clase

"Cómo utilizar otras herramientas para

comprender la Biblia"

\section{INTRODUCCIÓN}

A. La Biblia es su propio intérprete

B. Existen herramientas que facilitan su estudio

\section{DESARROLLO}

A. Herramientas denominacionales

1. Libros de Elena G. de White (Luz menor)

2. Comentario bíblico adventista

3. Biblioteca electrónica

B. Herramientas no denominacionales

1. Compendios biblicos

2. Atlas biblicos

3. Comentarios diversos

4. Diccionarios

5. Libros sobre teología

C. Otras herramientas

1. Léxicos

2. Vocabularios

3. Libros que estudian palabras teológicas

\section{CONCLUSIÓN}

A. Evaluemos cada una de las herramientas

B. Utilicemos la que se adecue a nuestra necesidad 


\section{Bosquejo para la clase}

"El lugar que los escritos de Elena G. de White ocupan en la Iglesia Adventista"

\section{INTRODUCCIÓN}
A. Breve biografia de Elena G. de White
B. Libros escritos por ella misma
C. Compilaciones por los editores

\section{DESARROLLO}
A. El don profético en la Biblia
1. Antiguo Testamento
2. Nuevo Testamento
3. Mujeres profetizas

B. Caracteristicas de un profeta verdadero

1. No contradice a los profetas bíblicos

2 . Vive de acuerdo a los principios biblicos

3. Sus profecías se cumplen

4. Confirma las promesas de la Biblia

C. El don profético en nuestros días

1. Pseudoprofetas (Nostradamus, la Niña de Fátima, Edgar Casey y Jeane Dixon)

2. Aplicación de las pruebas biblicas a E. G. W.

\section{CONCLUSIÓN}

A. Tenemos seguridad mediante la lectura de los libros de Elena G. de White.

B. Muchos pasajes bíblicos cobran sentido mediante los escritos de Elena G. de White 


\author{
4. Bosquejo para la clase \\ "Métodos de estudio para los niños"
}

\title{
I. INTRODUCCIÓN
}

A. Los niños en la Biblia

B. Mujeres de la Biblia que enseñaron a sus niños principios correctos

\section{DESARROLLO}

A. Formas de grabar lecciones en los niños

1. Historias

2. Dramatizaciones

3. Ilustraciones con objetos

4. Relatos de la vida real

B. Materiales devocionales para los niños

1. La Biblia de los niños

2. Cuéntame una historia

3. Casetes

4. Discos compactos

5. Otros materiales

C. Contextualizando la enseñanza

1. Cuna

2. Infantes

3. Primarios

4. Menores

\section{CONCLUSIÓN}
A. Los hijos son el tesoro más grande que Dios nos da
B. Dios nos pedirá cuentas de ellos
C. La educación empieza desde pequeños 


\section{Bosquejo para la clase}

"Base biblica y de EGW para los grupos pequeños"

\section{INTRODUCCIÓN}

A. Grupos pequeños del N. T.

B. Consejos de E. G. W. sobre grupos pequeños

\section{DESARROLLO}

A. Importancia de los grupos pequeños en la Iglesia Adventista

1. Al principio

2. Durante el desarrollo

3. Para la plantación de nuevas iglesias

B. Características de los grupos pequeños

1. Para su formación

2. Para mantener la unidad

3. Para mantenerlos vivos

4. Para su multiplicación

\section{CONSLUSION}

A. La iglesia necesita el ministerio de los grupos pequeños

B. Formar parte de un grupo pequeño ayuda a la madurez espiritual y social 
6. Bosquejo para la clase

"Importancia y ventajas de los grupos pequeños"

\section{INTRODUCCIÓN}

A. Los grupos pequeños en el desarrollo de la iglesia

B. Los grupos pequeños en movimientos religiosos protestantes

\section{DESARROLLO}

A. Los grupos pequeños por afinidad

1. De jóvenes

2. De profesionistas

3. Otros grupos afines

B. Los grupos pequeños según la zona geográfica

1. Grupos por familias

2. Ayudan a la evangelización

3. Pueden ser el inicio de una nueva iglesia

C. Los grupos pequeños como refuerzo doctrinal

1. Temas que se pueden estudiar

2. Facilidad para confraternizar

3. Enfatizan las relaciones sociales

\section{CONCLUSIÓN}

A. Los grupos pequeños son más manejables

B. La iglesia necesita trabajar mediante grupos pequeños 
7. Bosquejo para la clase

"Modalidades de los grupos pequeños"

\section{INTRODUCCIÓN}

A. Bases para los grupos pequeños

B. Necesidad de un grupo pequeño

\section{DESARROLLO}

A. Grupos pequeños por afinidad

1. De jóvenes en general

2. De mujeres

3. De adolescentes

4. De universitarios

B. Grupos pequeños formador por zona geográfica

1. De familias

2. Libre albedrio

C. Grupos ya conformados por la iglesia

1. De conquistadores

2. De guías mayores

3. De líderes juveniles

4. Otros grupos pequeños

\section{CONCLUSIÓN}

A. Cada miembros debe estar integrado

B. Que cada miembro elija el que mejor le guste 
8. Bosquejo para la clase

"Actividades que se pueden realizar en un grupo pequeño"

\section{INTRODUCCIÓN}

A. Los grupos pequeños son muy flexibles en sus actividades

B. Cada uno decide qué y cómo hacerlas

II. DESARROLLO

A. Confraternización

1. Grupos de dos o tres

2. Existe toral libertad para hablar

3. Se pueden conocer los problemas reales de los integrantes

4. Se encuentra solución entre ellos mismos

B. Recreación

1. Implementación de juegos didácticos

2. Recreación sana en ambiente sano

3. Fortalece los lazos de amistad

C. Libertad de participación

1. No existe presión de un programa formal

2. No existe presión de un púlpito

3. La participación es entre amigos

\section{CONCLUSIÓN}

A. El mismo grupo puede idear más actividades

B. Toda actividad debiera afirmar una enseñanza o un principio 
9. Bosquejo para la clase

"Cómo se multiplican los grupos pequeños"

\section{INTRODUCCIÓN}
A. El grupo se fortalece a medida que se reúne
B. Nuevos integrantes pueden llegar

\section{DESARROLLO}

A. Definiendo el número de integrantes

1. Ventajas de un número definido

2. Identificando el momento de dividir el grupo

3. Formando un nuevo líder de grupo

B. Nacimiento de un nuevo grupo

1. Asesoramiento por el pastor $u$ otro líder

2. Definiendo lugar, fechas y horario de reunión

3. Definiendo actividades del grupo

C. Maduración del grupo recién nacido

1. Creciendo nuevamente

2. Integración de amigos vecinos y familiares

\section{CONCLUSIÓN}

A. Los grupos pequeños pueden crecer "infinitamente"

B. Son una herramienta de avance territorial 
10. Bosquejo para la clase

"La importancia de la familia en la Biblia

y en los escritos de EGW"

\section{INTRODUCCIÓN}
A. La familia del Edén
B. Cómo afectó el pecado a la familia

\section{DESARROLLO}

A. Familias que contribuyeron positivamente

1. Familias de sacerdotes

2. Familias de profetas

3. Familias de reyes

B. Familias que influyeron negativamente

1. Familias de sacerdotes

2. Familias de profetas

3. Familias de reyes

C. Bases para una familia unida

1. Aspecto espiritual

2. Aspecto social

3. Comunicación y respeto

\section{CONCLUSIÓN}
A. La familia tuvo su origen en la mente de Dios
B. Debe ser restaurada a como era en el principio 
11. Bosquejo para la clase

"La participación de los niños en el culto familiar"

\section{INTRODUCCIÓN}
A. Jesús y los niños
B. Los niños sobresalientes de la Biblia

\section{DESARROLLO}

A. La importancia de instruirlos desde pequeños

1. "Instruye al niño en su camino..."

2. Un rincón para ellos en el culto

3. Jesús nos pedirá cuenta de ellos

B. Cómo pueden participar los niños

1. La lectura de las Escrituras

2. Las oraciones infantiles

3. Los cantos

C. Objetos que pueden ayudar a su enseñanza

1. Para caracterizaciones

2. Para reforzar lecciones

3. Otros materiales

\section{CONCLUSIÓN}
A. Los niños son propiedad de Jesús
B. Jesús quiere que la familia completa se salve 
12. Bosquejo para la clase

"Maneras de celebrar el culto familiar"

\section{INTRODUCCIÓN}

A. El culto familiar imprime lecciones duraderas

B. Forma hábitos que no se olvidan

\section{DESARROLLO}

A. Involucrando a los niños

1. Preescolares

2. Primarios

3. Menores

B. Involucrando a los jóvenes

1. Adolescentes

2. Mujeres

3. Hombres

C. Participación de los adultos

1. Padres

2. Abuelos

3. Otros

\section{CONCLUSIÓN}

A. el culto familiar es para todos

B. Deba ser variado para satisfacer las diferentes necesidades 
13. Bosquejo para la clase

"Ventajas de una familia cristiana unida y feliz"

\section{INTRODUCCIÓN}

A. La familia en el contexto bíblico

B. La familia cristiana moderna

\section{DESARROLLO}

A. Formadora de caracteres

1. El carácter es lo único que llevaremos al cielo

2. Una influencia contagiosa

3. Carácter y personalidad

B. La base de una iglesia espiritualmente sólida

1. La familia como una célula integral

2. Características de una familia adventista

3. Los hijos reflejan los principios enseñados en el hogar

C. La base de la sociedad

1. Cómo una familia cristiana puede ayudar en el vecindario

2. Cómo una familia cristiana influye en la comunidad

3. Alcances de un testimonio positivo

\section{CONCLUSIÓN}

A. La iglesia se fortalece con familias unidas

B. La parte devocional es clave en la unidad familiar 


\section{APÉNDICE C}

\section{EVALUACIÓN}

Evaluación del programa de entrenamiento

Esta evaluación ayudará a identificar las debilidades y fortalezas del plan de entrenamiento de líderes denominado "los doce apóstoles". Por favor conteste en forma sincera y al final coloque sus impresiones, observaciones y/o sugerencias.

Distrito Iglesia

Nombre del grupo

Nombre del apóstol Fecha de la evaluación

Número de personas asistentes

Conteste cada uno de los items donde el parámetro de respuestas es el siguiente:

5 , totalmente de acuerdo; 4 , de acuerdo; 3 , neutral; 2 , en desacuerdo; 1 , totalmente en desacuerdo.

1. Los temas eran de interés personal para usted

$\begin{array}{lllll}5 & 4 & 3 & 2 & 1\end{array}$

2. Hubo orden y lógica en la presentación

$\begin{array}{lllll}5 & 4 & 3 & 2 & 1\end{array}$

3. Todas las preguntas que surgieron fueron Contestadas satisfactoriamente

$\begin{array}{lllll}5 & 4 & 3 & 2 & 1\end{array}$

4. Los conceptos fueron presentados en forma clara

$\begin{array}{lllll}5 & 4 & 3 & 2 & 1\end{array}$

5. El contenido de la presentación fue totalmente bíblico

$\begin{array}{lllll}5 & 4 & 3 & 2 & 1\end{array}$

6. Se notó satisfacción en los oyentes al final de la presentación

$\begin{array}{lllll}5 & 4 & 3 & 2 & 1\end{array}$

7. Hubo aplicaciones a la vida práctica del cristiano

$\begin{array}{lllll}5 & 4 & 3 & 2 & 1\end{array}$

8. La presentación fue cristocéntrica

$\begin{array}{lllll}5 & 4 & 3 & 2 & 1\end{array}$


9. El contenido fue adecuado para las familias adventistas

$\begin{array}{lllll}5 & 4 & 3 & 2 & 1\end{array}$

10. Con toda confianza lo implementaría en su familia

$\begin{array}{lllll}5 & 4 & 3 & 2 & 1\end{array}$

Observaciones y sugerencias 


\section{APÉNDICE D \\ IDEAS PARA EL CULTO FAMILIAR}

\section{PREESCOLARES}

1. Usando un juguete, represente una historia de la Biblia.

2. Cante con el pequeño y la familia algún canto que se pueda representar.

3. El viernes de noche, encienda una vela y apáguela el sábado en la noche.

4. Encuentre libros apropiados para el nivel del pequeño y léalos mientras lo sostiene en sus brazos.

5. Tan pronto como los niños son capaces, póngalos a memorizar pequeñas frases de las Escrituras.

6. Los niños mayores pueden hacer un libro con ilustraciones que Ud. les sugiera.

7. Relate historias que ayuden a formar el carácter de los niños.

8. Re-escriba las historias de la Biblia en un vocabulario sencillo.

9. Dibuje las manos de los niños y hable acerca de las manos ayudadoras.

10. Dibuje el pie del niño y discuta usando pequeños pies para Jesús.

11. Cuente una historia al niño acerca de un milagro.

12. Arme un rompecabezas bíblico.

13. Muestre fotografias de Jesús y personajes bíblicos y cuente la historia.

14. Tenga fotografías de animales y cuente al niño que Jesús los hizo.

15. Ponga la música de la Escuela Sabática.

16. Enseñe a los niños a orar.

PRIMARIOS

1. El viernes haga preguntas sobre la lección de la Escuela Sabática.

2. Lea acerca de los frutos del Espíritu.

3. Haga que los niños preparen encuestas biblicas para sus padres.

4. Haga una caminata en la naturaleza.

5. Lea una historia espiritual y pida a los niños que identifiquen los valores presentados.

6. Escriba varios problemas de la vida diaria y pida a los niños que digan cómo los resolverían.

7. Encuentre una palabra que describa a Dios, Jesús o el Espíritu Santo con cada letra del abecedario.

8. Investigue el significado del nombre de cada niño.

9. Lea una historia sin mencionar el nombre del protagonista y vea quien es el primero en adivinarlo.

\section{JOVENCITOS Y ADULTOS}

1. Estudie y comparta con la familia las siguientes doctrinas: el sábado, el bautismo, la segunda venida y el estado de los muertos.

2. Lean cada día un capítulo de Proverbios.

3. Lea 1 Timoteo 4:12 y discutan lo que este versículo dice a los jóvenes. 
4. Encuentren una concordancia de textos que traten con "fortaleza" y discutan los versículos.

5. Busquen la palabra pruebas en el índice de los escritos de E. G. White y que cada persona localice información sobre pruebas y comparta con la familia.

\section{SOLTEROS}

1. Invite a una o más familias a unirse a ustedes para el culto.

2. Viaje hasta alguna clínica, etc. y haga el culto con la gente de allí.

3. Invite a los niños de su vecindario para contarles historias, leerles la Biblia, etc.

4. Visite a sus padres una vez a la semana y tenga el culto con ellos.

5. Encuentre a un compañero de oración.

6. Vaya a lugares especiales para tener el culto a Dios, tales como un río, jardín, etc.

7. Lea libros de devociones personales.

\section{CASADOS}

1. Hagan un libro de oraciones.

2. Lean un libro devocional juntos.

3. Comiencen el culto manifestando que cosa buena le pasó durante el día.

4. Lean un capítulo de la Biblia juntos.

5. Busquen en una concordancia todos los textos relacionados a las esposas y los esposos.

6. Individualmente, escriban una carta a Dios pensando en Él como un amigo.

7. Parafraseen un capítulo de la Biblia.

8. Subraye textos doctrinales y promesas en la Biblia.

9. Inviten a otra pareja a tener el culto con ustedes.

10. Tengan un cuarto especial para orar.

11. Tengan una fiesta de amor espiritual (Festín Ágape).

12. Hagan un libro de promesas.

13. Escriban notas de aprecio uno al otro.

14. Tengan una oración conversacional.

15. Mantengan un récorde oraciones contestadas en un libro de milagros.

16. Oren en voz alta.

17. Salgan a tener un culto en la naturaleza.

18. Trate de encender una vela o la chimenea en el culto del viernes de la noche.

19. Haga un libro personal de textos favoritos.

20. Hable acerca de su historia familiar.

21. Haga un folleto de gratitud.

22. Escojan un ministerio familiar.

23. Planee un servicio especial cuando los niños han sido llamados para aceptar a Jesús.

24. Lea El Deseado de todas las getes.

25. Dibuje una historia de la Biblia.

26. Que los niños tomen parte en la preparación de los cultos del viernes y sábado por la noche.

27. Haga un A-Z libro bíblico.

28. Lea el texto de "La Regla de Oro". Hagan "cupones de amor".

29. De pistas de un personaje bíblico y que los demás adivinen. 


\section{MENORES Y ADOLESCENTES}

1. Identifiquen las pruebas de un personaje bíblico.

2. Tengan un culto sobre las "hostilidades".

3. Mediante un curso bíblico

4. Encuentre libros sobre vida cristiana y léanlos juntos.

5. Escuchen CD's y cassettes de música religiosa.

6. Evalúen las películas ylos programas de televisión.

7. Disponga de suficiente tiempo para hablar sobre las amistades.

8. Tengan un tiempo establecido de metas.

9. Discuta sobre justicia, prejuicio, equidad, etc.

10. Asigne temas para ser estudiados.

11. Discutan el tiempo individual de devoción.

12. Decidan a quién pondrían en el salón celestial de la fama.

13. Discutan el plan de Dios para el matrimonio.

14. Tengan un culto telefónico cuando estén separados.

15. Dediquen un nuevo hogar teniendo oraciones en cada cuarto de la casa.

16. Alterne cultos vespertinos.

17. Decidan tener un día establecido para orar por los hijos que están lejos.

18. Invite a sus amigos para una fiesta de pascua.

19. Convierta las Escrituras en oraciones y apúntelas.

\section{IDEAS ADICIONALES CON LAS ESCRITURAS}

1. Lean acerca del Espíritu Santo.

2. El viernes por la noche lean textos bíblicos sobre el sábado.

3. Apunte ideas para la feliz observancia del sábado en el "Libro Familiar de Culto"

4. Estudien, de la Biblia, el carácter de Cristo.

5. En una serie de cultos descubran cómo es Cristo y oren por el Espíritu Santo.

6. Lean un capitulo de la Biblia juntos.

7. Cada uno visualice para sí mismo hacer lo que Dios manda.

8. Haga suyas algunas palabras de Jesús como si Él le estuviera hablando a usted.

9. Parafrasee o personalice un capítulo.

10. Dejen un texto de la Biblia sobre la mesa de desayuno.

11. Asigne un texto a la familia el viernes por la noche.

12. Estudien un libro difíil de la Biblia.

13. Lean acerca de los cielos en Salmos 8.

14. Lean y graben la escritura, usando un miembro de la familia como narrador.

15. Lea Mateo 14:23-33. 


\section{APÉNDICE E}

\section{FORMULARIO PARA EVALUAR EL TRABAJO DE LOS APÓSTOLES}

Nombre del apóstol

Familias asignadas

Territorio geográfico asignado

Total de integrantes de cada familia

Conteste cada uno de los items con una "X" según la respuesta adecuada

1. La visita a la familia se realizó con fidelidad cada día

Sí

No

A veces

2. Todos los miembros de la familia estuvieron reunidos a la hora indicada

Sí

No

A veces

3. Hubo participación activa de los padres

Sí

No

A veces

4. Se notó interés en todos los miembros de la familia

Sí

No

A veces

5. Al terminar cada día quedaron interesados para el siguiente

Sí

No

A veces

6. Cada día hubo espontaneidad en el culto familiar

Sí

No

A veces

7. Hubo interés en el estudio de la Biblia

Sí

No

A veces 


\section{APÉNDICE F}

PROGRAMA DE VISITACIÓN PASTORAL

Primer trimestre de 2003

Martes Director de escuela sabática de la iglesia central

Director de jóvenes

Secretario de la iglesia

Tesorero

Directora de dorcas

Miércoles Hermanos de la iglesia de Maravillas

Predicación en maravillas

Jueves Hermanos de la iglesia de San Lorenzo

Predicación en San Lorenzo

Viernes Hermanos de Pueblo nuevo III

Predicación en Pueblo nuevo III

Sábado Iglesia central

Martes Director de mayordomia de la iglesia central

Director de comunicación

Director de salud y temperancia

Director de educación

Miércoles Hermanos de la escuela sabática de Sonora

Predicación en Sonora

Jueves Hermanos de Arroyo Grande

Predicación en Arroyo grande

Viernes Hermanos de la escuela sabática de Los Pinos

Predicación en Los Pinos

Sábado Pueblo nuevo III

Martes Otros dirigentes de la iglesia central

Miércoles Hermanos de Rincón Chamula

Predicación en Rincón Chamula

Jueves Hermanos de la escuela sabática de La Loma

Predicación en La Loma 
Viernes Hermanos de Jitotol

Predicación en Jitotol

Sábado Los Pinos

Martes Miembros y dirigentes de Aurora Ermita

Miércoles Miembros y dirigentes de Jericó

Predicación en Jericó

Jueves Miembros y dirigentes de Los Lotes

Predicación en Los Lotes

Viernes Miembros y dirigentes de San Nicolás

Predicación en San Nicolás

Sábado Reunión de laicos

Martes Director de escuela sabática de la iglesia central

Director de jóvenes

Secretario de la iglesia

Tesorero

Directora de dorcas

Miércoles Hermanos de la iglesia de Maravillas

Predicación en maravillas

Jueves Hermanos de la iglesia de San Lorenzo

Predicación en San Lorenzo

Viernes Hermanos de Pueblo nuevo III

Predicación en Pueblo nuevo III

Sábado San Lorenzo y Los Lotes

Martes Director de mayordomía de la iglesia central

Director de comunicación

Director de salud y temperancia

Director de educación

Miércoles Hermanos de la escuela sabática de Sonora

Predicación en Sonora

Jueves Hermanos de Arroyo Grande

Predicación en Arroyo grande

Viernes Hermanos de la escuela sabática de Los Pinos

Predicación en Los Pinos 


\begin{tabular}{|c|c|}
\hline Sábado & Arroyo Gande y Sonora \\
\hline Martes & Otros dirigentes de la iglesia central \\
\hline Miércoles & $\begin{array}{l}\text { Hermanos de Rincón Chamula } \\
\text { Predicación en Rincón Chamula }\end{array}$ \\
\hline Jueves & $\begin{array}{l}\text { Hermanos de la escuela sabática de La Loma } \\
\text { Predicación en La Loma }\end{array}$ \\
\hline Viernes & $\begin{array}{l}\text { Hermanos de Jitotol } \\
\text { Predicación en Jitotol }\end{array}$ \\
\hline Sábado & Rincón Chamula \\
\hline Martes & Miembros y dirigentes de Aurora Ermita \\
\hline Miércoles & $\begin{array}{l}\text { Miembros y dirigentes de Jericó } \\
\text { Predicación en Jericó }\end{array}$ \\
\hline Jueves & $\begin{array}{l}\text { Miembros y dirigentes de Los Lotes } \\
\text { Predicación en Los Lotes }\end{array}$ \\
\hline Viernes & $\begin{array}{l}\text { Miembros y dirigentes de San Nicolás } \\
\text { Predicación en San Nicolás }\end{array}$ \\
\hline Sábado & Reunión de laicos \\
\hline Martes & $\begin{array}{l}\text { Director de escuela sabática de la iglesia central } \\
\text { Director de jóvenes } \\
\text { Secretario de la iglesia } \\
\text { Tesorero } \\
\text { Directora de Drcas }\end{array}$ \\
\hline Miércoles & $\begin{array}{l}\text { Hermanos de la iglesia de Maravillas } \\
\text { Predicación en maravillas }\end{array}$ \\
\hline Jueves & $\begin{array}{l}\text { Hermanos de la iglesia de San Lorenzo } \\
\text { Predicación en San Lorenzo }\end{array}$ \\
\hline Viernes & $\begin{array}{l}\text { Hermanos de Pueblo nuevo III } \\
\text { Predicación en Pueblo nuevo III }\end{array}$ \\
\hline Sábado & Maravillas y Jitotol \\
\hline Martes & $\begin{array}{l}\text { Director de mayordomía de la iglesia central } \\
\text { Director de comunicación }\end{array}$ \\
\hline
\end{tabular}


Director de salud y temperancia

Director de educación

Miércoles Hermanos de la escuela sabática de Sonora

Predicación en Sonora

Jueves Hermanos de Arroyo Grande

Predicación en Arroyo grande

Viernes Hermanos de la escuela sabática de Los Pinos

Predicación en Los Pinos

Sábado Jericó y San Nicolás

Martes Otros dirigentes de la iglesia central

Miércoles Hermanos de Rincón Chamula

Predicación en Rincón Chamula

Jueves Hermanos de la escuela sabática de La Loma

Predicación en La Loma

Viernes Hermanos de Jitotol

Predicación en Jitotol

Sábado La Loma y Aurora Ermita

Martes Miembros y dirigentes de Aurora Ermita

Miércoles Miembros y dirigentes de Jericó

Predicación en Jericó

Jueves Miembros y dirigentes de Los Lotes

Predicación en Los Lotes

Viernes Miembros y dirigentes de San Nicolás

Predicación en San Nicolás

Sábado Reunión de laicos

NOTA: Una copia de este cronograma debe ser entregada a cada anciano y encargado de iglesia y/o Escuela Sabática. 


\section{APÉNDICE G}

\section{AUTO-EVALUACIÓN DEL PROGRAMA DE VISITACIÓN PASTORAL}

Nombre del pastor Fecha

Iglesias para ser visitadas durante el mes

Blanco de familias para ser visitadas durante el mes

Evaluación

1. Porcentaje de familias visitadas según el blanco

2. Familias encontradas en casa

3. Familias no encontradas en casa

4. Iglesias visitadas según el objetivo

5. Sermones predicados en iglesias

Contesta cada uno de lis ítems donde el parámnetro es : 5 , muy de acuerdo; 4 , de acuerdo; 3 , neutral; 2 , en desacuerdo; 1 , totalmente en desacuerdo.

1. En forma general, las familias recibieron la visita del pastor de buen ánimo. $\begin{array}{lllll}5 & 4 & 3 & 2 & 1\end{array}$

2. Hubo suficiente confianza como para que las familias platicaran abiertamente. $\begin{array}{lllll}5 & 4 & 3 & 2 & 1\end{array}$

3. Se expresaron problemas personales y preocupaciones. $\begin{array}{lllll}5 & 4 & 3 & 2 & 1\end{array}$

4. Se proveyó solución por medio de la Biblia, la consejería y la oración. $\begin{array}{lllll}5 & 4 & 3 & 2 & 1\end{array}$

5. Hubo evidencias del fortalecimiento de la fe de los integrantes de la familia. 5

4

3

2 1

Observaciones 
Recomendaciones para realizar la visitación pastoral:

1. El propósito de la visita pastoral debe ser el bienestar espiritual de la gente.

2. La visita debe ser espiritual pero, a su vez, informal.

3. No debe pasar por alto a ninguno miembro de la familia.

4. Por regla general, la visita debe ser breve.

5. La visita pastoral debe ser confidencial.

6. El pastor debe recordar la recomendación de Pablo "que instes a tiempo y fuera de tiempo" (2 Ti. 4:2).

Actitud del pastor durante la visitación

1. Contacto empático, es decir, posibilidad de ponerse en lugar del otro y tratar de comprenderlo desde su perspectiva.

2. Calidez. El que entrevista demuestra que el otro no le resulta indiferente y siente por él un afecto no de lástima, sino de amor.

3. Espontaneidad. El pastor contribuye a crear un clímax de libertad, de creatividad y de permisividad. No significa que el que entrevista es un cómplice.

4. Iniciativa. El rol del pastor es esencialmente activo, que estimula la tarea y a la persona. No significa hablar todo el momento. Hay que saber escuchar.

5. Actitud docente. Significa encuadrar la actividad de la entrevista en un marco pedagógico, lo que implica movilizar todos los recursos didácticos para facilitar el aprendizaje. Se deben clarificar los objetivos: ¿qué es lo que la persona necesita modificar?

6. No tener actitudes paternalistas.

7. Claridad de expresión. ${ }^{2}$

Si la iglesia lo permite puede introducir un pequeño cambio en los cultos de entre semana. Es decir, en lugar de que el culto de acción de gracias sea el miércoles en las iglesias donde el pastor esté visitando los martes y los jueves, éste se puede cambiar a dichos días para que el pastor predique.

Para no sentirse fracasado porque llegó a la casa de algún hermano y éste no se encontraba, es necesario concertar citas previamente. El sábado durante los programas regulares puede ser una buena oportunidad para esto. También los diáconos y ancianos pueden proveer información de hermanos que requieran una visita pastoral.

\footnotetext{
${ }^{1}$ Hezekiah Harvey, "La visitación pastoral"

$<\mathrm{http}: / /$ amen.net/lb/articulos/pastor4.htm> (19 de abril de 2002).

${ }^{2}$ Jorge Bravo, "La tarea pastoral"

$<$ http://www.angelfire.com/pe/jorgebravo/tareapastoral.htm> (19 de abril de 2002).
} 


\section{APÉNDICE H $H^{3}$}

¿Estoy creciendo en mi madurez espiritual?

Si soy un

\begin{tabular}{|c|c|}
\hline Bebé espiritual & Evangelizar \\
\hline Párvulo espiritual & Evangelizar \\
\hline Muchacho espiritual & $\begin{array}{l}\text { Evangelizar } \\
\text { y enseñar }\end{array}$ \\
\hline Joven espiritual & $\begin{array}{l}\text { Evangelizar, consolidar, } \\
\text { enseñar } \\
\text { y equipar }\end{array}$ \\
\hline Padre espiritual & $\begin{array}{l}\text { Todo lo de arriba más } \\
\text { desarrollar a líderes } \\
\text { piadosos }\end{array}$ \\
\hline $\begin{array}{l}\text { Padre espiritual } \\
\text { con Timoteos }\end{array}$ & $\begin{array}{l}\text { Todo lo de arriba más } \\
\text { capacitar a líderes } \\
\text { quienes desarrollar a } \\
\text { otros líderes piadosos }\end{array}$ \\
\hline $\begin{array}{l}\text { Padre espiritual } \\
\text { Timoteos que enseñan } \\
\text { a hombres fieles ( } 2 \\
\text { Tim. 2:2) }\end{array}$ & $\begin{array}{l}\text { Todo lo de arriba más } \\
\text { desarrollar líderes } \\
\text { piadosos capaces de } \\
\text { comenzar nuevos } \\
\text { ministerios }\end{array}$ \\
\hline $\begin{array}{l}\text { Padres espiritual con } \\
\text { Timoteos quienes } \\
\text { equipan a hombres } \\
\text { fieles para enseñar a } \\
\text { otros }\end{array}$ & $\begin{array}{l}\text { Todo lo de arriba más } \\
\text { desarrollar líderes } \\
\text { piadosos para reproducir } \\
\text { ministerios }\end{array}$ \\
\hline
\end{tabular}

Mi liderazgo espiritual

Traerá división pronto a un grupo si se me da una posición de liderazgo espiritual

Traerá división pronto a un grupo si se me da una posición de liderazgo espiritual

Capaz de dirigir un grupo inestable por un tiempo. Puede causar una obra estable se convierta en una inestable.

Capaz de dirigir un grupo estable y ayudarlo a madurar y equipar

Capaz de producir un grupo estable que está creciendo y con liderazgo piadoso

Capaz de producir un grupo estable que está creciendo y con. líderes piadosos que están también desarrollando a líderes piadosos

Capaz de producir un grupo estable que está creciendo y que está enviando líderes a comenzar nuevos ministerios

Capaz de desarrollar ministerios reproductivos están produciendo líderes piadosos y reproduciéndose a si mismos

La lista de arriba demuestra la importancia crítica de continuar creciendo en nuestra madurez espiritual si queremos ver al Señor usar nuestras vidas para que cause un impacto de crecimiento.

${ }^{3}$ Anderson, 15. 


\section{APÉNDICE I ${ }^{4}$ \\ CÓMO CRECER AL SIGUIENTE NIVEL DE MADUREZ ESPIRITUAL}

\section{Hazte las siguientes preguntas:}

1. ¿He experimentado el nacimiento espiritual? Enfoque del bebé espiritual: Comida espiritual

a. ¿Tengo un hambre verdadera por la comida espiritual? - I Ped. 2:2

b. ¿Tengo un deseo de aprender la Palabra de Dios y ser obediente a ella? - Stg. 1:22

2. ¿He comenzado a crecer y después he parado o retrocedido? Enfoque del párvulo espiritual: Mis necesidades, mis problemas

Las Escrituras nos dan por lo menos diez características de párvulos espirituales:

¿Habrá algunas de estas que describan mi vida espiritual en este momento?

a. ¿Actúo a menudo como alquien que no es cristiano? - I Cor. 3:1

b. ¿Se me hace dificil entender enseñanzas dificiles? - I Cor. 3:2

c. ¿Experimento a menudo envidia, disensión y divisiones? - I Cor. 3:3

d. ¿Está limitado mi habla, entendimiento, y pensamiento de cosas espirituales? - I Cor. 13:11

e. ¿Soy fácilmente confundido por enseñanzas falsas? - Ef. 4:14

f. ¿Tengo dificultad en reconocer a los falsos maestros? - Ef. 4:14

g. ¿Soy insensible para escuchar verdad espiritual? - Heb. 5:11

h. ¿Es neceesario que se me enseñe las cosas básicas del cristianismo? - Heb. 5:12

i. ¿Carezco de habilidad al usar la palabra de justicia? - Heb. 5:13

j. ¿Tengo los sentidos desarrollados para reconocer el bien y el mal? - Heb. 5:14 Otras preguntas importantes que te puedes hacer:

a. ¿Dependo de mis propias fuerzas? - Rom. 7:14-25. O cedo a Dios y dependo de su fuerza? - Rom. 6:13-16, Rom. 8:1-39

b. ¿Estoy motivado por temor o por amor? - I Juan 4:18, II Cor. 5:14-15

c. ¿Estoy caminando en la carne o caminando en el Espíritu? - Gal. 5:13-26

3. ¿Estoy creciendo y llegando a ser un muchacho espiritual? Enfoque del muchacho espiritual: Crecimiento espiritual

a. ¿Tengo la seguriadad que mis pecados han sido perdonados? - I Juan 2:12

b. ¿De verdad conozco al padre o solamente acerca de El? - I Juan 2:13

c. ¿Estoy llegando a ser fuerte en espíritu? - Luc. 1:80, Luc. 2:40

d. ¿Estoy caminando en comunión con Dios y con otros cristianos? - I Juan 1:3-7

e. ¿Estoy enfocando en que el amor de Dios crezca y madure en mi vida? - I Juan 2:3-6

${ }^{4}$ Anderson, 16, 17. 
4. ¿Estoy creciendo y llegando a ser un joven espiritual? Enfoque del joven espiritual: Servir

a. ¿He llegado a ser fuerte en espíritu? - I Juan 2:14

b. ¿Ha llegado a la que palabra de Dios habita en mi corazón? - I Juan 2:14

c. ¿He vencido a Satanás y como consequencia estoy experimentando gozo y victoria? - I Juan 2:13-14

d. ¿He escogido seguir a Cristo en vez de cosas materiales? - Mt. 19:20-22

5. ¿Estoy creciendo y llegando a ser un padre espiritual? Enfoque del padre espiritual: El cuidado de hijos espirituales

a. ¿Tengo uno o mas hijos espirituales a los cuales ayudo regularmente en su crecimiento espiritual? - I Cor. 4:14-17

b. ¿Dirijo a mis hijos espirituales por mi amor? - I Tes. 2:7-9

c. ¿Dirijo a mis hijos espirituales por mi ejemplo? - I Tes. 2:10-12

d. ¿Estoy continuamente profundizando mi relación personal con Dios? - I Juan $2: 12-14$

\section{6. ¿Estoy creciendo y llegando a ser un padre espiritual con Timoteos?}

Enfoque del padre espiritual con Timoteos: El desarrollo espiritual piadoso

a. ¿Tengo a uno o más Timoteos que ya están ejercitando liderazgo espiritual? Hch. 16:1-3

b. ¿Llevo a Timoteos conmigo cuando ministro? - Hch. 20:4

c. ¿Le doy responsabilidad a Timoteos a ayudar a otros? - I Cor. 4:17

d. ¿Estoy ayudando a Timoteos a aprender a reproducirce? - II Tim. 2:2 


\section{BIBLIOGRAFIA}

Anderson, Duane L. Manual de entrenamiento para lideres de grupos pequeños. Norwalk, CA.: American Indian Bible Institute, 1996.

Anderson, Roy Alan. The Shepherd-Evangelist: His Life, Ministry, and Reward. Washington, DC: Review and Herald, 1950.

Arizmendi Esquivel, Felipe. "La pluralidad religiosa: Riqueza cultural de Chiapas". $<$ http://www.laneta.apc.org/curiasc/foro20-21 Abril.htm> (15 de junio de 2002).

Arn, Win. The Church Growth Ratio Book. Pasadena: Church Growth, 1987.

Barna, George, ed. Leaders on Leadership. Ventura: Regal, 1997.

Barrientos, Alberto. Principios y alternativas del trabajo pastoral. Miami: Caribe, 1989.

Bautista Bautista, José Luis. Plan de desarrollo municipal, 2002-2004. Pueblo Nuevo Solistahuacán, Chis.: Presidencia municipal, 2002.

Beasley-Murray, George. John. Word Biblical Commentary, 36. Dallas: Word, 1987; Logos Library System, 1995.

Bland, James C. "How to Close the Back Door". Christianity Today, 17 enero 1986, 74.

Bond, Stephen B. Spiritual Authority, God's Way of Growing Leaders. Joplin, MO: College Press, 1995.

Bradford, Charles. Predicación para estos tiempos. Hagerstown, MD: Review and Herald, s.f.

Bravo, Jorge. "La tarea pastoral". <http://www.angelfire .com/pe/jorgebravo/tareapastoral.htm> (19 de abril de 2002).

Bultmann, Rudolf. "Menō". Diccionario exegético del Nuevo Testamento. 3 vols. Editado por Horst Balz y Gerhard Schneider. Traducido por Constantino RuizGarrido. Salamanca: Sígueme, 1998. 2:222-224.

Burrill, Russell. The Revolutionized Church of the 21st Century. Fallbrook, CA: Hart Research Center, 1997. 
Burrill, Russell. Recovering an Adventist Approach to the Life and Mission of the Local Church. Fallbrook, CA: Hart Research Center, 1998.

Calkins, Raymond. El romance del ministerio. Boston: Pilgrim, 1943.

Comentario bíblico adventista. 7 vols. Editado por F. D. Nichol. Traducido por V. E. Ampuero Matta. Boise: Publicaciones Interamericanas, 1978-1990.

Consejo Estatal Técnico de la Educación, Antología: Cosas y casos de mi tierra. Tuxtla Gutiérrez, Chiapas: Consejo Estatal, s.f.

Cress, James A. You Can Keep Them If You Care: Helping New Members Stay on Board. Silver Spring, MD: Ministerial Association Resource Center, General Conference of Seventh-day Adventists, 2000.

Dana, H. E., y Julius R. Mantey. Manual de gramática del Nuevo Testamento griego. El Paso: Casa Bautista, 1975.

Davis, Guillermo H. Gramática elemental del griego del Nuevo Testamento. El Paso: Casa Bautista, 1988.

Departamento de Secretaría, Sección Norte de Chiapas. Entrevista por el autor, Pichucalco, Chis., 17 de octubre de 2000.

Dudley, Roger L. Why Our Teenagers Leave the Church. Hagerstown, MD: Review and Herald, 2000.

Edwards, Rex D. Cada creyente, un ministro. Silver Spring, MD: Asociación Ministerial, Asociación General de la Iglesia Adventista del Séptimo Día, 1999.

Enhanced Strong's Lexicon. Compubiblia. Logos Library System, 1995.

Gerber, Vergil. God's Way to Keep a Church Going and Growing. South Pasadena: William Carey, 1973.

Getz, Gene. "Becoming A Spiritually Mature Leader". En Leaders on Leadership, ed. George Barna, 81-108. Ventura: Regal, 1997.

González, Justo. "Discípulo" Diccionario ilustrado de la Biblia. Editado por Wilton M. Nelson. Miami: Caribe, 1981. 170-171.

"Grupos pequeños". <http://www.tagnet.org/laicos/grupos/grupos_peq2.htm> (13 de junio de 2002).

Hartman, Warren J. Membership Trends: A Study of Decline and Growth in the United Methodist Church, 1949-1975. Nashville: Discipleship Resources, 1976. 
Hauck, F. "Menō". Theological Dictionary of the New Testament. 10 vols. Editado por Gerhard Kittel y Gerhard Friedrich. Traducido por Geoffrey W. Bromiley. Grand Rapids: Eerdmans, 1964-1976. 4:574-588.

Harvey, Hezequiah. "La visitación pastoral". <http://amen.net/lb/articulos/ pastor4.htm> (14 de julio de 2002).

Instituto Nacional de Estadística, Geografia e Informática. "Ejidos y comunidades agrarias, según actividad principal, uso del suelo y parcelamiento por municipios con $30 \%$ y más de población indígena". <http://www.ciesas.edu.mx/ bibdf/ini/estatal/chiapas/13_anexo.html $>$ (13 de junio de 2002).

Johnson, Kurt W. Grupos pequeños para el tiempo del fin. Miami: Asociación Publicadora Interamericana, 1999.

Kittel, Gerhard, y Gerhard Friedrich, eds. Theological Dictionary of the New Testament. 10 vols. Traducido por Geoffrey W. Bromiley. Grand Rapids: Eerdmans, 19641976.

Kuhne, Gary W. La dinámica de adiestrar discipulos. Nashville: Caribe, 1980.

Kysar, Robert. John. Augsburg Commentary on the New Testament. Minneapolis: Augsburg, 1986.

Lawrenz, Mel. The Dynamics of Spiritual Formation. Grand Rapids: Baker, 2000.

Lewis, Jonatán P., ed. Misión mundial: Un análisis del movimiento cristiano mundial. 3 vols. Miami: Unilit, 1990.

Lewis, Larry L. Manual para plantar iglesias. Traducido por Edgar Morales. El Paso: Casa Bautista, 1997.

López Pérez, Pablo, primer adventista del séptimo dia en Pueblo Nuevo Solistahuacán, Chiapas. Entrevista por el autor, Pueblo Nuevo Solistahuacán, Chiapas, 10 de junio de 2002.

Márquez, Rolando, secretario de la Sección Norte de Chiapas durante el período 19982002. Entrevista por el autor, Pichucalco, Chiapas, 15 de abril de 2002.

Martín, Carlos. Cómo trastornar al mundo. Traducido por Rolando A. Itin. Buenos Aires: Casa Editora Sudamericana, 2000.

Martin, Glen, y Gary McIntosh. The Issachar Factor: Understanding Trends That Confront Your Church and Designing a Strategy for Success. Nashville: Broadman and Holman, 1993. 
McIntosh, Gary, y Glen Martin. Finding Them, Keeping Them: Effective Strategies for Evangelism and Assimilation in the Local Church. Nashville: Broadman and Holman, 1992.

McKibben, Jorge Fitch. Nuevo léxico griego-español del Nuevo Testamento. El Paso: Casa Bautista, 1978.

Ministerio de la mujer de la Unión Chilena. "Proyecto: Ministerio de conservación". $<$ http://www.adventistas.cl/minmuj.htm> (17 de julio de 2002).

Nichol, Francis D., ed. Comentario biblico adventista. 7 vols. Traducido por V. E. Ampuero Matta. Boise: Publicaciones Interamericanas, 1978-1990.

"Nuestra naturaleza social". <http://www.tagnet.org/ficoa/advent/esabatica/ e1999203.htmi\#domingo> (13 de junio de 2002).

Orozco Zuarth, Jorge A., y Marco A.Orozco Zuarth. Geohistoria de Chiapas. México, D. F.: Offset California, 1996.

Pérez, Nicolás, pastor jubilado de la Sección Norte de Chiapas y pionero de la Iglesia Adventista del Séptimo Día en Pueblo Nuevo Solistahuacán, Chiapas. Entrevista por el autor, Pueblo Nuevo Solistahuacán, Chiapas, 10 de junio de 2002.

Prado Flores, José H. Formación de discípulos. México, D. F.: Kerygma, 1998.

"Pueblo Nuevo Solistahuacán". <http://www.elchiapaneco.com.mx/V/ munis/ pueblo\%20nuevo $\% 20$ solistauacan $>$ (13 de junio de 2002).

Rainer, Thomas S. High Expectations: The Remarkable Secret for Keeping People in Your Church. Nashville: Broadman and Holman, 1999.

Robledo Hernández, Gabriela. "Pueblos indígenas de México". $<$ http://www.ini.gob.mx/ monografias/tzotziles.html> (13 de junio de 2002).

Roehlkepartain, Jolene L. Youth Ministry: Its Impact on Church Growth. Loveland, CO: Group, 1989.

Samaan, Philip G. Christ's Way of Reaching People. Hagerstown, MD: Review and Herald, 1990.

Savage, John S. “The Teflon Church”. Leadership 11 (otoño 1990): 30-37.

Schaller, Lyle E. Assimilating New Members. Nashville: Abingdon, 1978. The Small Church Is Different!. Nashville: Abingdon, 1982. 
Schnackenburg, Rudolf. El evangelio según san Juan: Versión y comentario. Traducido por Claudio Gancho. Barcelona: Herder, 1980.

Schwarz, Christian A. Desarrollo natural de la iglesia: Ocho características básicas de una iglesia saludable. Barcelona: CLIE, 1996.

Schweer, G. William. La evangelización personal para hoy. El Paso: Casa Bautista, 1992.

Seminarios de la División Sudamericana. "Prevención apostasía". Disco 1.

Seventh-day Adventist Encyclopedia. Edición revisada. 2 vols. Editado por Don Neufeld. Hagerstown, MD: Review and Herald, 1996.

Smith, Donald P. Empowering Ministry: Ways to Grow in Effectiveness. Louisville: Westminster/John Knox, 1996. How to Attract and Keep Active Church Members. Louisville: Westminster/John Knox, 1992.

Steinbron, Melvin J. Can the Pastor Do It Alone? A Model for Preparing Lay People for Lay Pastoring. Ventura: Regal, 1987.

Turner, Gordon Bruce. Outside Looking In. Toronto: United Church, 1987.

Vine, W. E. Diccionario expositivo de palabras del Antiguo y del Nuevo Testamento. Nashville: Caribe, 1999.

Vocabulario griego del Nuevo Testamento. Biblioteca de estudios biblicos minor, 5. Salamanca: Sígueme, s.f.

Wagner, Peter. "Las cuatro estrategias de la misión”. En Misión Mundial, ed. Jonathan P. Lewis, 2:96-104. Miami: Unilit, 1990.

Warren, Rick. Una iglesia con propósito, Cómo crecer sin comprometer el mensaje y la misión. Traducido por Cecilia de Francesco. Miami: Vida, 1998.

White, Elena G. de. Alza tus ojos. Buenos Aires: Casa Editora Sudamericana, 1982.

. Cada dia con Dios. Mountain View, CA: Pacific Press, 1979.

. El camino a Cristo. Mountain View, CA: Pacific Press, 1979.

. El colportor evangélico. Buenos Aires: Casa Editora Sudamericana, 1978.

. El conflicto de los siglos. Mountain View, CA: Pacific Press, 1957. 
White, Elena G. de. Consejos para los maestros. Mountain View, CA: Pacific Press, 1972.

. Consejos sobre la obra de la escuela sabática. Coral Gables, FL: Asociación Publicadora Interamericana, 1976.

. El discurso maestro de Jesucristo. Mountain View, CA: Pacific Press, 1956.

En lugares celestiales. Mountain View, CA: Pacific Press. 1968.

. El evangelismo. Miami: Asociación Publicadora Interamericana, 1994.

. Exaltad a Jesús. Coral Gables, FL: Asociación Publicadora Interamericana, 1988.

. Los hechos de los apóstoles. Mountain View, CA: Pacific Press, 1977.

. El hogar cristiano. Mountain View, CA: Pacific Press, 1959.

. Joyas de los testimonios. 3 vols. Mountain View, CA: Pacific Press, 1971.

. ¡Maranata: El Señor viene! Mountain View, CA: Pacific Press, 1976.

. Mensajes para los jóvenes. Mountain View, CA: Pacific Press, 1967.

. Mensajes selectos. 3 vols. Mountain View, CA; Pacific Press, 1984.

. El ministerio de la bondad. Buenos Aires: Casa Editora Sudamericana, 1963.

. El ministerio pastoral. Silver Springs, MD: Asociación Ministerial.

Asociación General de los Adventistas del Séptimo Día, 1995.

. Obreros evangélicos. Buenos Aires: Casa Editora Sudamericana, 1971.

. Testimonies for the Church. 9 vols. Mountain View, CA: Pacific Press, 1948.

. Testimonios para los ministros. Mountain View, CA: Pacific Press, 1977.

Wiersbe, Warren W. Bosquejos expositivos de la Biblia, Antiguo Testamento y Nuevo Testamento. Nashville: Caribe, 1995. 


\section{CURRÍCULUM VÍTAE}

Moisés Espinoza Almazán

Nacido en 1959

Ordenado al ministerio en 1989

EDUCACIÓN:

1982 Licenciatura en Teología, Universidad de Montemorelos

1995 Maestría en Religión, Andrews University, Extensión Montemorelos

2002 Doctorado en Ministerio, Andrews University, Extensión Montemorelos

\section{EXPERIENCIA PROFESIONAL}

1982-1985 Pastor de distrito, Asociación del Norte, Unión Mexicana

1985-1992 Pastor de distrito, Asociación Central, Unión Mexicana

1992-1993 Capellán del Centro Educativo Ignacio Manuel Altamirano, Asociación Central.

1993 Pastor de distrito, Asociación Pacífico Sur.

1993-1995 Profesor de la Escuela de Teología, Colegio Linda Vista, Chiapas, México

1995- Director de la Escuela de Teología, Universidad Linda Vista, Chiapas, México 